\title{
İslâmcılığın Türkiye Serüveni: Kadınların İlâhiyat Tecrübesine Katkıları
}

\section{Prof. Dr. Hatice K. ARPAGUŞ*}

Öz: İslâmcılığın Türkiye serüvenini incelerken göz önünde bulundurulması gereken başlıklar arasında kadın konusu gelmektedir. Ancak İslâmcılık denilince de bunun temellerinin Osmanlı'da atılmış olması, öncelikle meselenin Osmanlı'yı da dikkate alan tarihsel boyutuna gitmeyi kaçınılmaz kılmaktadır. Cumhuriyet dönemine gelince bu konuda söz konusu İslâmcılık cereyanının toplumsal yapıda görünür olması, din eğitimi kurumlarının açılması ve kadınların buralarda bulunmalarıyla mümkün olmaktadır. Bu amaçla konunun seyri takip edilirken söz konusu kurumların hangi zeminde ve hangi ihtiyaçlar göz önünde bulundurularak açıldıklarının incelenmesi konumuz açısından önemlidir. Kız öğrencilerin kurumsal yapıya dâhil olmaları ise devlet ile halkın, modernleşme ile İslâm’nn din eğitimi kurumlarından sonra karşılaşmalarının diğer önemli bir veçhesini oluşturmuş ve oldukça sancılı süreçlerden geçerek bugüne gelmiştir. Kız öğrencilerin bu tür kurumlarda bulunmaları hem devletin halka karşı tavrının netleşmesinde, hem de halk ile devletin zaman zaman birbirinden uzaklaşıp zaman zaman da birbirine yaklaşma fırsatı yakalamasında önemli fonksiyon icra etmiştir. Söz konusu süreçte onların kamusal alanda bulunabilmelerinin mümkün olup olmadığı, bulunacaklarsa dinî kimlikleriyle olup olamayacakları, sayılarının ne kadar olacağı gibi normalde meseleye dâhil olmaması gereken konular da hep tartışma alanına çekilen hususlar arasında yer almıştır.

Anahtar kelimeler: Osmanlı ve İslamcılık, Modernleşme ve Kadın, Din Eğitimi Kurumları: İmam Hatip Liseleri-İlahiyat Fakülteleri, Başörtü Problemi, Din Eğitimindeki Anayasal Kisitlamalar.

\section{The Adventure of Islamism in Turkey: The Contribution of Women to Islamic Studies}

\begin{abstract}
When we study the adventure of Islamism in Turkey, among other things we need to have a look on is the issue of women. However, the roots of the subject lies in Ottoman times, hence we have to go back to Ottoman times and to have a historical understanding of the issue. In the Republican times the issue started when Islamic institutions were opened and women appeared in the Islamic movements after they started to show up in Islamic intuitions. Hence it is also important to study the causes and conditions why these institutions were opened. Another important subject to study is how female students became part of these institutions, how state and people confronted each other in the process of modernization since all these processes were quite problematic for both sides. The participation of the girls in these institutions made states' approaches to Muslim masses more crystallized. This process sometimes caused the state alienating the Muslim masses from itself and sometimes created an opportunity to close the gap between the state and people. In these process some other interesting subjects that will be studied are whether women could show their
\end{abstract}

* Marmara Üniversitesi İlahiyat Fakültesi Öğretim Üyesi, arpagush@marmara.edu.tr 
Muslim identity in the government offices, what will be the number of the female students. These are subjects that causes a lot of unnecessary tension will be covered in this article.

Keywords: Ottoman State and Islamism, Modernization and Woman, Institutions for Religious Education: Religious Vocational (Imam Hatip) High Schools-Theology Faculties, The Problem of Headscarf, Constitutional Restrictions in Religious Education

\section{Giriş}

Kız öğrencilerin Cumhuriyet döneminde din eğitimi kurumlarına katılmaları kökleri Osmanlıya dayanan İslâmcıllğın bir yansıması olarak görülmesi gereken bir durumdur. Her ne kadar İslâmcılığın temellerinin Osmanlı'da atılmış olduğu bilinmekle birlikte Cumhuriyet döneminin başlangıcında şartlar gereği sessiz kaldığı, 1970'lerden itibaren da varlık sahasına çıktığı görülmektedir. Bu durum onun Cumhuriyet döneminde bazı değişim ve dönüşüm yaşayarak hayatiyetini devam ettirdiğini göstermektedir. Özellikle burada ele alınacak olan din eğitimi kurumlarının tesisi, diğer eğitim kurumları arasında yer almaya çalışmaları ve kız öğrencilerin buralarda bulunması, İslâmcılığın söz konusu ilk nüvelerinden birini oluşturmaktadır. Dolayısıyla bugün kadınların İlahiyat tecrübesine katkısı başlığı kaçınılmaz olarak İslamcılığın tarihsel tecrübesini dikkate almayı gerekli kılmaktadır. Bundan ötürü makalede öncelikle din eğitimi kurumlarının kısa bir tarihçesi ve kız öğrencilerin bu yapı içindeki durumu incelenecektir. Çünkü bugünü değerlendirebilmek için öncelikle sürecin bütününe bakmak, hangi şartlarda ve tarihsel yapıda ortaya çıktığını belirlemek gerekmektedir. Kadının toplumsal hayata katılması veya din eğitimi kurumlarında öğrenci olması konusu, geleneksel hayatta yaygın bir durum değildir. Dolayısıyla meselenin teorik temellerinin atıldığı ve ilk uygulama alanı içinde Osmanlı modernleşme tecrübesinin yer aldığı dikkati çekmektedir. Söz konusu tecrübe XIX. yüzyılda başlamakla birlikte bugüne kadar gelen süreci etkilemiş olması ve kendisinden sonraki gelişmelere katkı sağlaması açısından önemlidir. Ancak bir makalede bu kadar uzun bir zaman dilimini incelemek tahmin edileceği üzere oldukça zordur. Bu açıdan dönemin öne çıkan niteliklerinden hareketle konuyu ele almak yerinde olacaktır. Bu amaçla kısaca Tanzimat dönemine gitmek, sonrasında da Cumhuriyet dönemi modernleşme çabalarına bakmak uygun olacaktır. Cumhuriyet dönemi modernleşme çabaları da 1980 ve 1990’lı yıllara gelene kadar büyük oranda Batıcı ve seküler tarzda geliştiği kabul edilmektedir. Cumhuriyet dönemine geçişle büyük oranda Batıcı ve Türkçü bakış açılarının hâkim olması, toplumun yeniden inşasında dinî değer ve kabullerden ziyade Kemalist bir yaklaşımın tercih edilmesine denk gelmektedir. İslâmcılığın görünür olması denilince de 1970’lerden itibaren başlayan ve günümüze kadar gelen dönem ön plana çımaktadır. Türkiye'de İlahiyat tecrübesini incelemek de din eğitimi veren kurumların Cumhuriyet dönemindeki durum ve konumlarına bakmayı gerekli kılmaktadır. Bu da bir manada Cumhuriyet dönemi İslâmcıllğıını mercek altına almak demektir.

Din eğitimi kurumlarının var olma çabasına geçmeden önce ana hatlarıyla İslamcılık ve Batıcılığı Türkiye Cumhuriyeti özelinde mukayese etmek anlamlı olacaktır. Batılı modernleşme tecrübesi doğrudan Batıyı esas aldığından ve Batılı değerler üzerinden hareket 
ettiğinden öngördügü hayat, toplumunun temel dinamikleriyle uyum sağlayıp sağlamadığını dikkate aldığı söylenemez. Dolayısıyla Batılı modernleşme tecrübesi, bir manada Türkiye özelinde hem başarılı olamamış, hem de taraftarlarının toplumdan uzaklaşarak toplumsal değerlerden yabancılaşmasına sebebiyet vermiş bir uygulama olarak görülmektedir. İslâmcı hareket ise metot açısından batılı modernleşme yanında dînî değerleri de referans aldığından daha gerçekçi ve uygulanabilir bir ilerlemeyi hedeflemiştir. Bu açıdan Osmanlı dönemi İslâmcılığı incelendiğinde onun hakkında söylenebilecek ve ön plana çıkacak hususların başında Osmanlı İslâmî değerleri referans alma prensibinden hareket ettiği ve modern tecrübeyi de bu çerçevede dikkate aldığı belirtilebilir. Dolayısıyla o, "kökü mazide olan âtı̂” söylemiyle, gelenekten hareket etme prensibini esas almıştır.

\section{Tarihçe}

\section{Osmanlı Modernleşmesi:}

Modernleşme süreci Osmanlı'da bir taraftan idarî askerî ve hukukî alanlarda gelişmelere imzasını atarken diğer taraftan da toplumsal alanda kadının kamusal alana katılıp katılmamasıyla ilgili söylemler etrafında gelişme göstermiştir. Dolayısıyla bu çaba ister istemez kadınların toplumsal alanda görünür olmalarına ve yeni açllan eğitim kurumlarında bulunmalarını beraberinde getirmiştir. Böylece toplumun yarısını teşkil eden kadının kamusal alanda görünürlügünün teminiyle, Osmanlı toplumsal modernleşmesi hayata geçirilmeye çalışılmış, böylece kadınlar Osmanlı toplumunun yüzünü Batı medeniyetine çeviren önemli alanlarında bulunmuşlardır. ${ }^{1} \mathrm{Bu}$ gelişmeler neticesinde de kadınla ilgili olarak kadın hakları veya kadının konumu gibi hususlar, Batılaşma meselelerinde nirengi noktasındaki hususlar arasında yer almıştır. Bu durum kadın konusunun toplumun hemen her katmanının, hatta siyasetin de meselesi olmasına vesile olmuştur. Şüphesiz bu noktaya gelişte, Osmanlı modernleşmesinin kadın haklarını esas alarak İslâm toplumuyla Batı arasındaki karşıtlığı aşmaya çalışmasının da önemli bir payı vardır. Çünkü Batı aydınlanma çağının fikirleri ve sanayi medeniyeti ile modernliğin tanımını ve liderliğini üstlendikçe Doğu toplumları iktidarsızlaştırmış ve onları kendi yerlerini ve tarihlerini Batı modeline göre belirlemek zorunda bırakmıştır. Dolayısıyla kadın konusu Doğu ile Batı arasındaki farklılığı simgeleyen unsurların başında yer almış ve sadece Müslüman toplumların Batıyla ilişskisini değil, aynı zamanda Batı’nın Doğu’yla ilişkisini de belirlemiştir. ${ }^{2}$

Bu durum Osmanlı'da Tanzimat fermanıyla birlikte gözle görülür bir takım değişikliklerin başlamasını hızlandırmış ve 1856 Islahat Fermanı’nda hiç kimsenin cinsiyetinden dolayı ikincil duruma düşemeyeceği ifade edilmiştir. ${ }^{3}$ Aynı çaba neticesinde Tanzimat'la kadın hukukî düzlemde kazanımlar elde ettiği gibi, eğitim konusunda da birçok haklar elde etmiş ve yeni açlan kurumlarda okuyabilme fırsatını yakalamıştır. Hatta kadının eğitimi resmî düzenlemelerle hukuksal bir statüye de kavuşturulmuştur. 1868'de Maarif-i Umûmiye Nizamnamesi 6-11 yaşlarındaki tüm kız çocuklarının ilkokul eğitimi almalarını öngörmüştür. İlk anayasa olan Kanunî Esasî ise kadın erkek tüm Osmanlı nüfusunun ilkokul eğitimi

1 Ömer Çaha, Sivil Kadın, Ankara 1996, s. 86-87.

2 Nilüfer Göle, Modern Mahrem, İstanbul 1993, s. 11, 13.

3 Çaha, s. 88. 
almasını zorunlu kılmıştır. Bu durum Osmanlı yönetiminin kadın eğitimine önemli ölçüde kaynak aktarması ve tüm ülkede bu meseleyi adeta bir seferberlik ilanı olarak kabul etmesi şeklinde tezahür etmiştir. Söz konusu faaliyetler neticesinde kadınlar kamusal alanda istihdam edilmeye başlamışlardır ki bu bağlamda bir kadının 1873’te ilk defa öğretmen olarak atandığı, 1881'de okul töreninde konuşma yaptığı, 1883'te de okullarda idareci olmaya başladıkları gözlemlenmektedir. ${ }^{4}$

Osmanlı modernleşmesinin topluma yönelik kısmında kadınla ilgili hususlar odak noktada yer alırken dönemin İslâmcıları da kendi medeniyet projesini hayata geçirme açısından bu konuya destek vermişlerdir. Kadının toplum hayatına katılması modernliği hayata geçirirken tesettürlü olması da aynı oranda İslâmî yaşamı benimsemesinin bir göstergesidir. Bu durum Osmanlı kadın tartışmalarının İslâmcı modernleşmenin ana parametrelerini ön plana çıkarması açısından önemlidir. Böylesi bir tartışma modernleşme sürecinde önemli bir döneme tekabül etmekte ve önemli bir tecrübe olarak değerini korumaktadır.

\section{Osmanlı İslamcılı̆̆ı ve Kadın}

İslâmcı Osmanlı aydınları bu meseleye karşı sessiz kalmamışlar, kadınların toplumsal alana katılmalarını tasvip etmekle birlikte aile hayatının sekteye uğratılmaması konusunda 1srarcı olmuşlardır. Çünkü İslâmî perspektiften bakılınca toplumun en küçük, ancak en önemli unsuru kabul edilen aile mefhumunun vazgeçilmez fonksiyonları bulunduğu ve onun bir barınak ve sığınaktan öte bir konuma sahip olduğu kabul edilmektedir. Dolayısıyla her ne kadar onlar kendi içlerinde birbirinden farklı bakış açılarına sahip olsalar da kadının modern hayata katılması sırasındaki en büyük endişeleri, aile mefhumunun zarar görmesi çerçevesi yönündedir. Meselâ dönemin önemli yayın organları arasında bulunan Sırât-ı Müstakîm ve Sebîlürr-reşâd'da İslâmcı yazar ve edip Mehmed Akif Ersoy Ferid Vecdînin el-Mer'etü'l-müslime/Müslüman Kadımı adlı eserini bölümler halinde yayınlarken bu konuları geniş çerçeveden incelemiştir. ${ }^{5}$ Yine İslâmcı bir dergi olan Hikmet müelliflerinin de feminizme karşı çıkmalarının altında aynı saikın yattığı görülmektedir. Nitekim onlar feminizmin hem kadını hem de toplumu yok edecek bir süreci başlatacağını düşündüklerinden bu konuya destek verilmesini, salt Batı’yı taklit olarak değerlendirmişlerdir. $\mathrm{Bu}$ bakış açısından hareketle de feminizmin yalnızca dine değil toplumsal hayata da çok büyük zararlar vereceği düşüncesini dile getirmişlerdir. Cumhuriyet döneminde dinin toplumsal

4 Çaha, s. 88-90.

5 Bu dönemdeki tartışmalar çok geniş perspektifte incelenmeye müsaittir ve Cumhuriyet dönemindeki kadın konusundaki uygulamaların temel teorik alt yapısını oluşturacak zemini sunmaktadır. Burada özellikle Batıcıların kadın konusundaki bakış açılarına bakmak, Cumhuriyet dönemi uygulamalarını görmek açısından önem arzetmektedir. Ancak Cumhuriyet döneminde yoğun tartışma alanlarından birini oluşturan tesettür meselesi konusunda Osmanlı Batıcıları, Türkçüleri ve İslâmcıları birbirlerinden farklı bakış açıları ortaya koymuş olmakla birlikte Cumhuriyet dönemindeki gibi yasaklanması gerektiği noktasına gelmemişlerdir. M. Ferid Vecdi’nin konuyla ilgili "Müslüman Kadını: Dokuzuncu Fasıl: Tesettür Kadınların Nişâne-i Esâreti midir, Yoksa Zamin-i Hürriyeti midir?” (Sırât-ı Müstakîm, İstanbul, 1324, I, sy. 11, s. 173-176), “Tesettür Kadınların İktisâb-1 Kemâl Etmelerine Mâni ' midir?” (Sırât-ı Müstakîm, I, sy. 13, s. 203-205), “Tesettür Kalkar mı” (Sırât-ı Müstakîm I, sy. 15, s. 234-236) , "Yine Tesettür Meselesi” (Sebîlürreşâd, XI, sy. 276, s. 241-243) adlı makaleleri bunlardan yalnızca birkaçını oluşturmaktadır. Bundan başka Sırât-ı Müstakîm’de Mehmed Fahreddin’in ardarda konuyla ilgili sekiz tane "Medeniyet-i İslâmiyye'den Bir Sahîfe Yâhûd Tesettür-i Nisvân" adlı yazıları bu çerçevedeki makaleler arasında zikredilebilir. 
alanda görünür olması, din eğitimi kurumlarının durumu ve kız öğrencilerin buralarda bulunmaları, Osmanlı döneminde oluşturulan teorik alt yapının uygulama alanı gibi görünmektedir ve aşağıda müstakil başlıklar altında ele alınacaktır.

\section{Cumhuriyet Modernleşmesi}

Cumhuriyet dönemine gelince daha karmaşık bir yapıyla karşılaşacağımızı ifade ederek başlamak anlamlı olacaktır. Nitekim aşağıda ayrıntısı görüleceği üzere laik Cumhuriyet açısından "kadınların dinî kimliğiyle kamusal alanda görünür olmak istemeleri, en sancılı meselelerin başında gelmektedir" demek, yanlış olmasa gerekir. Ayrıca Cumhuriyet bir yandan Osmanlı tecrübesi üzerine gelişirken diğer yandan batılılaşma politikasını daha ileri safhalara götürmüştür. ${ }^{6}$ Bu durum birbirinden tamamıyla zit görünümlü modernleşme tecrübelerinin din ve kadın konularına yansıyarak sancılı süreçlerden geçmesine sebebiyet vermiştir. Ancak bu konuları incelerken Cumhuriyet dönemini yekpâre görmek yerine kendi içindeki gelişmeler ve dönemler çerçevesinde ele almak daha uygundur. Meselâ tek parti sisteminde öne çıkan politikalar ile çok partili sistemi bir birinin aynı değildir, çok partili dönemi de 10 yılda bir gündeme gelen ihtilal ve muhtıralar bağlamında ele alınması gerekmektedir. Ancak İslâmî istek ve beklentilerin görünürlügüunün 1970'li yıllarda başlayıp 1980 ve sonrasında daha açık bir şekilde ortaya çıktığı tespit edilmektedir. Tek parti dönemi bir yandan Cumhuriyet rejimin temellerinin atıldığı ve sıkı bir laiklik politikasının uygulandığı, diğer taraftan da devletin halktan uzaklaşarak tabanın isteklerini dikkate almadığ 1 zaman olarak değerlendirilmektedir. Bu durum hem devletin halktan, hem de muhâfazakar çevrenin devletten uzaklaşmasına ve kendi içinde farklı mecralar aramasına sebebiyet vermiştir. Bu durum iki dönem modernleşme projeleri mukayese edildiğinde Osmanlı dönemi modernleşme mimarları müslüman kalarak ve bunun farkında olarak modernleşirlerken Cumhuriyet ideolojisinin ise en yumuşak tabirle İslâm ve Müslümanlı̆̆ı paranteze alarak modernleşme projesini yürüttüğü söylenebilir. Bundan ötürü Cumhuriyet döneminde devletin sık sık İslâmî uygulamaların kamusal alanlarda görünür olmasına müsaade etmemeyi tercih ettiği dikkati çekmektedir. ${ }^{7}$

6 Cumhuriyet’in temellerinin aslında Osmanlı döneminde neşvünema bulan Batıcılar tarafından atıldığı söylenebilir. Kadın konusundaki bakış açıları ve uygulamalarda bu husus görüldüğü gibi din eğitimi alanında da çok net bir şekilde ortaya çıkmaktadır. Nitekim ileride din eğitimi kurumları işlenirken görüleceği üzere Tevhîd-i Tedrîsat Kanunu Batıcı düşünürler tarafından medresenin ilgası olarak yorumlanmış ve uygulamaya konmuştur. Din eğitimi kurumlarının tarihinde bunun ne kadar büyük sıkıntılar ortaya koyduğu dönemin tanıkları tarafından ifade edilmektedir. Söz konusu kanunu bu şekilde anlayan Maarif vekili Hüseyin Vasıf Efendi’nin uygulamaları Batıcı yazar Abdullah Cevdet tarafından dergisi İçtihâd'da desteklenmektedir. Nitekim o, burada Vasıf beyi çok cesur bulmakta ve medreseyi tefessüh etmiș bir kurum olarak lanse etmektedir. Medresenin yerine de Fransız ve Anglo-Sakson eğitim sistemini getirmenin gereklerinden ve avantajlarından bahsetmektedir (bk. Abdullah Cevdet, “Müşterek Terbiye, Tevhîd-i Tedrîsat”, İctihâd İstanbul, 1924, XIX, sy. 168, s. 3397-3402). Bu amaçla o, Anglo-Sakson eğitim sisteminin faydalarını ve işlevselliğini konu edinen bir seri makale ele almış John Dewey’den de tercümeler yaparak konunun fikri temellerini atmıştır.

7 Konunun geldiği noktayı tüm yönleriyle incelemek makalenin sınırlarını aşacak mahiyettedir. Ancak bu dönem uygulamalarında ön plana çıkan hususları Batılı değerleri ön planda tutmak, Laiklik ve Kemalizm'in dinle eşdeğer bir şekilde toplumsal hafızada işlev görmesini öngörmek şeklinde özetlemek mümkündür. Dolayısıyla bu sırada esas alınan noktalarda taassup mubah, tolerans da günah addedilmektedir. Nitekim Vedat Nedim Tör'ün Dinimiz adlı eserinde Kemalizm'in İslâm yerine geçecek bir din şeklinde sunulduğu görülmektedir. Bu amaçla o, Kemalizm'in bir iman halinde içe sindirilmesini ve bütün nesillere benimsetilmesini gerekli görmektedir (geniş bilgi için bk. İsmail Kara, Cumhuriyet Türkiyesinde Bir Mesele Olarak İslâm, İstanbul 2008, s. 28). 
Şüphesiz modernleşme teorilerinin hayata geçirilmesi meselesini bütün olarak değerlendirmeden doğrudan kadının konumuyla ilgili alanlara yoğunlaşmak, konunun anlaşılmasını kısıtlayabilir. Bundan ötürü kadın konusuna gelmeden önce, dinin kamusal alanda görünür olup olamaması yanında eğitimde dinî yönün bulunup bulunmayacağı din eğitimi kurumların varlığı gibi hususlara değinmek yerinde olacaktır. Bu amaçla din eğitimi kurumları açılmadan önce ve açılma sırasındaki dönemin önemli simalarının tespitlerine bakmak meseleyi daha anlaşılır kılacaktır. Meselâ eğitimin millî mi dinî mi olması gerektiği yönündeki tartışmayı gündeme getiren İsmayıl Hakkı Baltacıoğlu’nun Tevhîd-i Tedrîsat Kanunu’ndan bir ay kadar önceki aktarımı bunlardan birini oluşturmaktadır:

Atatürk terbiye dinî mi yoksa millî mi olmalı? sorusunu bana soruyordu. Bütün dikkatimi topladım ve şu cevabı verdim: "Din toplumsal bir kurumdur. Toplum hayatında yaşamaktadır. Fakat devlet, onu okullarında öğretmeye mecbur değildir. Devlet eğitiminin karakteri ancak ulusal olabilir. Devrim eğitim kurumlarını lâikleştirmelidir... Cevabımın iyi karşılandığını seziyordum...”

Baltacıoğlu, bu konuşmasından yaklaşık 25 yıl sonra Ankara Üniversitesi İlâhiyat Fakültesi’nin açılması Meclis’te müzakere edilirken yaptı̆̆ konuşmada ise geçmişteki fikirlerinin topluma uyum sağlamadığını şu şekilde dile getirmektedir:

"Yeni nesilde bir nevî̀ şahsiyet zaafı vardır. Bu bizde yoktur. Çünkü politik şeâmet bir tarafa, bizim neslin formasyonu bütündür, dinî terbiye almıştır. Formasyon bütün olmazsa bir aralık şahsiyette tezatlar başlar. Ben ancak 50 yaşından sonra şu kanaate vardım, bunu bu kürsüden açıkça söylemekten çekinmem, bütün ahlâkî, bedîi ve lisanî kültürü aldıktan sonra bir insan, dini formasyona tâbî tutulmazsa şahsiyette bütünlük olmuyor. Dinî tecrübe de beşer tecrübesinin bir şekli, bir nevî̀ mahsusudur. Bu işin başını boş bırakırsak yani ilim adamlarının elinden alırsak, bu İlahiyat Fakülte’si ve dinî kültüre ait neşriyat olmazsa nâ-ehillerin eline düşer, sapıklar çoğalır, anormaller, psikopatlar hiçbir devirde bu kadar artmamış, hiçbir memlekette bu kadar çoğalmamıştı."

Yine aynı dönemlerle Diyanet İşleri Başkanı Ahmed Hamdi Aksekili’nin 1950 yılında dinî tedrisatla ilgili raporunda önemli noktaları işaret ettiği dikkati çekmektedir. Bunlar arasında din eğitiminin kesintiye uğramasının hem gençlikte hem de halkta dinî buhrana sebebiyet vermesi hususu gelmektedir. Bundan ötürü o, bizde dinî konularda yaşanan buhranın altında maneviyata vurulan darbe bulunmaktadır diyerek meseleyi şu şekilde dile getirmektedir:

a) 430 numaralı Tevhîd-i Tedrîsât Kanunu’nun tatbikatı İslâm dinine ait her türlü din müesseselerini ilga etmekle neticelenmiş olması;

b) Mekteplerdeki din tedrisatının kaldırılması,

8 İsmayıl Hakkı Baltacıoğlu, Hayatım, İstanbul 1998, s. 294-295. Nitekim 1943’te Tip Fakülte’sinde okuyan Ayşe Hümeyra Öktem Hanım bu yıllardaki okullarda dine karşı tutumu şu şekilde değerlendirmektedir: O zaman Müslüman gözükmek ayıptı. Hiç böyle şeyler konuşulmazdı. Hocalarla, kapalılarla, ibadet edenlerle dalga geçilirdi, benim öyle arkadaşlarım vardı ki dindar gözükmeyi ikinci sınıf insan olarak kabul ederlerdi (Nevin Meriç, Dindar Bir Doktor Hanım: Ayşe Hümeyra Ökten, İstanbul, 2011, s. 107).

9 Halis Ayhan, Türkiyéde Din Eğitimi, İstanbul 2014, s. 220-221. 
c) Bu kadarla da kalmayarak hariçte ve mekteplerde din aleyhtarlığ propagandaları yapilmasi,

d) Anayasa din ve vicdan hürriyetini teminat altına almasını, ailelerin kendi çocuklarına din dersleri okutmalarına, Anayasa'dan başka Medenî Kanunun da müsait bulunmasına rağmen tatbikatta buna meydan verilmemesi. Değil din dersi sadece Kur'ân-1 Kerîm okuyanların bile suçüstü halinde dillerinde Kur'an olduğu halde mahkemelere sevk olunması,

e) Milli Eğitim Bakanlığı’nın Tevhîd-i Tedrîsat Kanunu'yla yetiştireceğini taahhüt ve deruhte ettiği yüksek din mütehassısları ile imam hatip gibi din adamlarını yetiştirmemesi. Bu suretle Diyanet İşleri Başkanlığı̉nın muhtaç olduğu dinî elemanlardan ve memleketin hâkîkî din adamlarından, hatta namaz kıldıracak imamlardan mahrum birakılması,

f) Azınlıklarda bile din adamları yetiştiren muazzam din müesseseleri olduğu halde Diyanet İşleri Başkanlığı’nın kolej şeklinde olsun bir meslek mektebi olmaması ve buna müsaade edilmemesi, ${ }^{10}$

Bundan başka o, Diyanet İşleri Başkanlığı’na kuruluş amacına uygun hareket edebilme imkânı verilmediğini de şöyle dile getirmektedir:

3 Mart 1340 tarih ve 429 sayılı kanunla teşekkül eden Diyanet İşleri Başkanlığı dinî işleri tedvir etmek, cami ve mescitleri idare eylemekten sorumludur. Başkanlık köylere kadar uzanan bu vazifesini layıkıyla yapabilmek için İslâm dininin bütün inceliklerine, Şark ve Garp felsefesine vakıf yüksek din adamlarına, halkımızı irşat edecek kudretli müftülere, vaizlere kendisine hürmet telkin ettirecek imam ve hatiplere muhtaçtır. Bunları Millî Eğitim Bakanlığı yetiştirecekti, ancak Tevhîd-i Tedrîsat Kanunu’yla bütün dinî kurumlar ona devredilmiştir. Fakat sonradan bu müesseselerin kapatılmış ve kapanmış, Tevhîd-i Tedrîsat adı altında evvela bu kurumlar Maarif vekâletine devredilmiş, ancak Askerî mektepler tekrar Millî Savunma bakanlığına iade edildiği ve birçok vekâletlere meslekî mekteplere verildiği halde Diyanet İşleri Başkanlığı̉na böyle bir salahiyet verilmemiştir. Hâlbuki papaz mekteplerine asla dokunulmamıştır. İslâmî mekteplerin tamamen kapanması yüzünden din adamları o kadar azaldı ki köylerin çoğunda cenaze yıkayacak adam bile bulunamaz oldu. Bu ihtiyacı değişik zamanlarda muhtelif makamlara yaptığımız müracaatlarla verdiğimiz raporlarla belirttik. Nihayet büyük Millet Meclisỉnin geçen devresinde sunulmuş olan iki layihada bu cihet açılandı. Bu layihalarda dinî ihtiyaç ve bunun sebepleri bütün üryanlığıyla gösterilerek Diyanet İşleri Başkanlığı’na bağlı dinî bir kurumun açılması lüzumu belirtilmiştir. Bu haklı ve yerinde talep hususî bir komisyona havale edilmiş, neticede istenilen din müesseseleri yerine, Üniversite’ye bağlı bir İslâm İlahiyat Fakültesi açılmasına, ilk mekteplerin dördüncü ve beşinci sınıflarında ihtiyarî din dersi konulmasına imam hatip ihtiyacını karşılamak üzere de Millî Eğitim Bakanlığı tarafından on aylık kurslar açılmasına karar verilmiştir. ${ }^{11}$

10 Ahmed Hamdi Aksekili, “Din Tedrisatı ve Din Müesseseleri Hakkında Rapor”, Cumhuriyet Türkiyesìnde Bir Mesele olarak Din (haz. İsmail Kara), İstanbul 2008, s. 148-149.

11 Aksekili, s. 150-151. 
Aksekili gibi Ali Fuad Başgil de devletin hem Tevhîd-i Tedrîsat Kanunu hem de laiklik ilkesinden hareketle din konusundaki uygulamalarının toplumu korkunç bir kargaşaya sürüklediğini ve adeta uçurumun kenarına getirdiğini şu şekilde anlatmaktadır:

Bizde devlet adamları laik olduklarını ilan ettikleri halde, İslâmiyet'in ibadet ve usul adabına, hatta ibadet diline müdahale etmekte bir beis görmezler. Bu hususta elde bulunan bin bir misalden birini zikredeyim: vaktiyle Beşiktaş semtindeki camilerden birinde imamlık vazifesi yapan yaşlı bir zat günün birinde Arapça ezan okumakla suçlanarak yakalanmış, evinden ve ailesinden koparılıp Bursa'ya sürgün edilmiştir. ${ }^{12} \mathrm{Bu}$ örnek din konusundaki tazyikleri göstermesi açısından anlamlıdır. Seneler içinde uygulanan bu tür müthiş sindirme ve baskı politikası, bu memlekette hem dinin yaşanmasını zorlaştırmış, hem de yüksek ehliyette din âlimi yetişmesine ve yüksek vasıfta din eseri çıkmasına engel olmuştur. Bundan ötürü din bahsinde toplumun düşünce dünyasında kapkara bir cehalet hâkim olmuştur. Dolayısıyla din ve maneviyat konusunda Türkiye her tarafından tutuşmuş ahşap bir konak gibidir. Bu mücerret bir iddia değil, gören gözler için apaçık bir hakîkattir. Şu kadarını söyleyeyim ki eğer bu durum tez elden giderilmeye çalışılmaz da bu buhran devam ederse Türkiye'yi komünizm pençesine düşmekten kurtaracak bir kuvvet tasavvur edilemez. Kim ne derse desin ben bu sözümün tarihe mal olmasını istiyorum. ${ }^{13}$

Bütün bu yorum ve açıklamalar tek partili dönemde laiklik, Tevhîd-i Tedrîsat gibi uygulamalarla dinî konularda toplumun korkunç bir cehalete sürüklediğini ortaya koymaktadır. Dönemin tanıklarının hemen hepsi bu girdaptan kurtulmanın reçetesinin ivedilikle din eğitimi kurumlarının açılmasında görmüşlerdir. Bu açıdan kısaca bugünkü İmam Hatip liseleri ile İlahiyat fakültelerinin tarihî tecrübelerini incelemek uygun olacaktır. Yine bu bağlamda bu tür kurumlarda kız öğrencilerin ne zaman ve hangi şartlarda eğitim sürecine katıldıkları sorusunu sormamız da gerekecektir.

\section{4. İmam Hatip Liselerinin Tarihçesi}

İlahiyat Fakültesi öncesinde din eğitimi veren orta öğretim kurumları İmam Hatip liseleridir. Tarihçesine baktığımızda İmam Hatip liselerinin başlangıçtan günümüze kadar şu aşamalardan geçtiğini görürüz. Bu okulların ilk nüvesi olan Medresetül-eimmetü ve'lhuteba 1913'te açılmış, ancak Tevhîd-i Tedrîsat Kanunu gereğince tüm medreseler kapatılmıştır. Daha sonra 1924’te imamlık ve hatiplik gibi dini hizmetlerinin yerine getirilmesi amacına binaen ülke genelinde 29 merkezde ilkokula dayalı 4 yıllık İmam Hatip mektepleri açılmıştır. Söz konusu mektepler, dinle ilgili derslerin kısıtlı olması gibi değişik sebeplerden ötürü sayısı önce 26, sonra 20'ye 1929'da 2'ye düşürülmüş, 1930'de de “öğrenci yokluğu” bahanesiyle tamamen kapatılmıştır. Fakat bu okulların kapanmasının asıl sebebi sorumlu makamların ilgisizliği ve mezunlarının, gerek öğrenimlerini sürdürme gerekse mesleklerine yönelme açısından istikbale dair bir beklentilerinin kalmaması gibi temele dayanmaktadır. Nitekim mezun olanların İlahiyat Fakülte'sinde öğrenimlerine devam edebilme imkânının bulunmaması yanında 1926'da bir kısım din görevliliği kadrolarının kaldırılması, 1927'de Şûrâ-yı Devlet'in aldığı bir kararla din görevliliğinin "me’murîn" sınıfından sayılmaması

12 Ali Fuad Başgil, Din ve Laiklik, İstanbul 1991, s. 143.

13 Başgil, s. 228-229 
bütün elemanların görevden uzaklaştırılmasına sebebiyet vermiştir. Bütün bu etmenler de İmam Hatip mekteplerini işlevsiz hale getirmiștir. ${ }^{14}$

1930-1948 yılları arasında ülkede din eğitimi veren hiç bir okul kalmamıştır. Bu da ülkenin dinî konularda oldukça zorlu süreçlerden geçmesine sebebiyet vermiştir. 1949'da çok partili döneme geçişle birlikte bu ihtiyacı karşılamak amacıyla İmam Hatip Yetiştirme Kursları açılmıştır. Ortaokul mezunu askerliğini yapmış kimselerin 10 ay süreli eğitim almasını hedefleyen söz konusu kurslardan ilk yıl 50 kişi mezun olmuş, süreleri daha sonra iki yıla çıkarılmış ve meslek okulu mezunlarının da girmesine imkân verilmiş, ancak meslekî açıdan çok yetersiz olan bu kurslar da 1951'de kapanmıştır. ${ }^{15}$

1951'de İmam Hatip okulları 4 yıllık ortaokul ve 3 yıllık liseden oluşan orta öğretim kurumu olarak ülke genelinde yedi ilde (Adana, Ankara, Isparta, İstanbul, Kayseri, Konya, Kahraman Maraş) açılmıştır Söz konusu uygulama neticesinde 4 yıllık ortaokulu bitirenler isterlerse imam hatip olabilme imkânı elde etmeye başlamışlardır. Lise kısmını bitirenlerin yükseköğrenim kurumlarına gidebilmeleri, ayrıca düz lise fark derslerini verdikten sonra mümkün olmaktadır. Ancak 1971 askeri muhtırası bu kurumların yeniden sıkıntılı bir sürece girmelerine sebebiyet vermiştir. Bu sırada 1972'de İmam Hatip Okulu idare yönetmeliği hazırlanmış ve bu yönetmelikle hukuk dışı birçok uygulama yürürlüğe konmuştur. Bunlardan biri okullarının öğretim sürelerinin yeniden düzenlenerek 4 yıllık ortaokulların 3 yıla, 3 yıllık liselerin de 4 yıla çıkarılmasıdır. Ancak 3 yıllık ortaokul kısımları, İmam Hatip Okuluyla aynı çatı altında bulunmakla birlikte müfredatından meslek dersleri kaldırılmıştır. Böylece okulların isminden başka İmam Hatip’le hiçbir alakası kalmamış, hatta kısa bir zaman sonra da (22 Mayıs 1972) tamamen kapatılmışlardır. Böylece okullar yalnızca dört yıllık meslek liseleri haline getirilmiş ve liseden mezun olanların yükseköğretimin tüm programlarında okuma imkânı engellenerek eğitimde fırsat eşitliği ilkesi askıya alınmıştır. Diğer bir kısıtlama da İmam Hatip Okulu idare yönetmeliğinin öğrenci kayıt kabul şartlarıyla ilgili 117. maddesinin d fikrasındadır. Söz konusu yönetmeliğe göre İmam Hatip okullarında okumak için "erkek olmak" şartı getirilmiştir. Bu durum anayasa ve yasalardaki

14 Halis Ayhan, “İmam Hatip Lisesi”, DİA, XXII, 191. Aslında bu eğitim kurumlarının kapanma gerekçelerini “öğrenci yokluğu" şeklinde ifade edilmesi, tarihî vakalarla uyum sağlamamaktadır. Konuya dair sınırlı sayıdaki çalışma bunun gerekçesinin öğrenci yokluğu olmadığını ortaya koymaktadır (geniş bilgi için bk. Mustafa Öcal,"Kuruluşundan Günümüze İmam Hatip Liseleri”, Din Eğitimi Araştırmaları Dergisi, 1999, sy. 6, s. 201-254). Bunun yanında İlahiyat Fakültesi’nin açılmasıyla ilgili meclis zabıtları incelendiğinde bu okul mezunlarının İlahiyat Fakültesỉne öğrenci olarak girememesi, her iki kurumun da başlangıçlarında işlevsiz bir zeminde inşa edildiklerini göstermektedir. $\mathrm{Bu}$ açıdan söz konusu kurumların her ikisi de zaman içinde kapanmak durumunda kalmışlardır. Ancak aşağıda ayrıntısı görüleceği üzere Ankara İlahiyat Fakültesi açıldığında onun da uzun bir süre İmam Hatip lisesi değil de düz lise mezunlarını kabul etmesi tesadüf olmasa gerektir. Dolayısıyla bu kurumların tarihsel gelişimleriyle ilgili daha derin araştırmaların yapılması gerektiği anlaşılmaktadır. Özellikle tartışmaların geçtiği meclis kayıtlarının ve kurumların arşivlerinin incelenmesi bize daha sağlıklı neticelere ulaştıracak zemini verecektir

15 Söz konusu kursların açılmasına şahit olan Ayşe Hümeyra Ökten Hanım konuyu şu şekilde anlatır: imam yetiştiren on aylık bir kurs açılması için emir geldi. Babam o zaman felsefe hocası Fransızcada biliyor ya onlara göre modern hocaydı. Babam "bu on aylık kursta ancak ezan okunması öğretilir, müezzin imam yetişmez dedi" ama açılması için de çok uğraştı. İlk açıldığında itibar eden yok, çok az kişi gelmiş, kurs neredeyse kapanacak babam sokaktan ameleleri toplamış, "kaç para kazanıyorsunuz ben vereyim yeter ki gelin sınıfta oturun müfettiş geldiğinde öğrenci yok diye kursu kapatmasın" demiş. Öğrenci sayısının yirmi kişinin altına düşmemesi gerekiyormuş, bir de "İmam Hatip mektepleri nasıl olmalıdır? Diye layiha hazırlattılar. Babam bir sene hazırlık üç sene ortaokul üç sene lise toplam yedi yıllık okul nizamını hazırlayıp Ankara’ya gönderdi. Ne var ki niyetler halisane olmadığından o komisyona havale bu komisyona havale sonra encümene derken böyle üç sene geçti (Meriç, s. 75). 
“eğitimde firsat eşitliği ilkesi”ne ters düştügünden bir velinin konuyu Danıştay’a götürmesi sonucu 1976'da iptal edilmiş ve o tarihten itibaren kız öğrenciler İmam Hatip liselerine kayıt yaptırmaya başlamışlardır. ${ }^{16}$ Yine 1973 'te yürürlüğe giren Millî Eğitim Temel Kanunu’na göre okulların orta kısımları yeniden açılmış, liseler de 4 yıla çıkarak İmam Hatip Lisesi adını almışlardır. Bu düzenlemeden sonra öğrenciler düz lise edebiyat kolu mezunu statüsüne gelmişler ve diğer liselerin edebiyat kollarıyla eşit seviyede üniversiteye girebilme hakkını ilk defa elde etmişlerdir. Teoride bunlar olurken mezunların üniversiteye gidebilmeleri ancak 1976/1977'den sonraya denk gelmektedir. 12 Eylül 1980 askeri darbesi sırasında mevcut okullara müdahale edilmemekle birlikte yeni okul açılmasına izin verilmemiştir. Bu dönemde kız öğrencilere de başörtüsü yasağı getirilmiştir. 1982 Anayasasına göre hazırlanan Temel Eğitim Kanunu'nun 32. maddesinde yapılan bir değişiklikle İmam Hatip Lisesi mezunlarının ilk defa üniversitelerin tüm bölümlerine girebilme imkânı sağlanmıştır. 28 Şubat 1997 askeri darbesi sırasında da temel eğitim sekiz yıla çıkarılarak İmam Hatip liselerinin ortaokulları kapatılmış ve katsayı engeliyle mezunlarının alanları dışında herhangi bir üniversiteye girmeleri engellenmiştir. Bu süreç Adalet ve Kalkınma Partisi iktidarının hükümette neredeyse onuncu yılına kadar düzeltilememiştir. 2011 yılında yapılan yeni düzenlemelerle yükseköğretime geçişte uygulanan katsayı engeli kaldırılmış ve İmam Hatip liseleri diğer lise mezunları gibi üniversiteye girişte tekrar eşit haklara sahip olmuşlardır. 2012'ye gelindiğinde de İmam Hatip liselerinin ortaokul kısımları tekrar açılmıştır.

Yukarıda kısaca tarihini anlattığımız kısımdan da anlaşılacağı üzere İmam Hatip liselerinin açılması, toplumun din hizmeti ihtiyacını karşılamaya yönelik bir teşebbüstür ve daha da önemlisi neredeyse tamamen ortadan kalkmaya yüz tutmuş din âlimi yetiştirme amaçlı birinci basamak eğitim kurumlarıdır. Söz konusu dinî ihtiyaçların başında da imam hatiplik mesleği gelmektedir. Ancak toplumun din konusundaki ihtiyacı imam hatiplik mesleğine inhisar edilmekten çok daha geniş bir alana tekabül etmektedir. Diğer bir ifadeyle imam hatiplik, bu konunun bir veçhesini oluşturmakla birlikte tek veçhesi değildir. Bu durum otomatik olarak mezunlarının bir üst kademe eğitim kurumlarına gitmek istemeleri şeklindeki taleplerinin gündeme gelmesine vesile olmuştur. Ancak mezunlar açısından tabîi görülen bu istek, dönemin siyasal yapısı tarafından normal olarak değerlendirilmemiş olduğu izlenimi vermektedir. Nitekim kurumların yapılandırılması sırasında yükseköğrenime gidip gitmemeleri, giderlerse nasıl gidebilirler? gibi soruları oldukça uzun bir zaman diliminde cevaplandırılmaya çalışılmıştır. Elde edilen hakların da yeni bir ihtilal döneminde tekrar elden çıktığının gözlenmesi, bu kurumların normal olarak kabullenilmediklerini göstermektedir. Bütün bu gelişmeler 2011 yllından sonra normalleşme sürecine girmiş olmakla birlikte ileriye yönelik yeni müdahalelere zemin teşkil etmemesi temenni edilmektedir.

$\mathrm{Bu}$ kurumların açılışından kısa bir süre sonra öğrencilerin cinsiyeti ne olmalıdır şeklindeki sorunun cevabının da verilmesi gerekmiştir. İlk defa kursların açıldığı dönemlerde amaç yalnızca imam hatip mesleğini icra edecek eleman yetiştirilmesi olduğundan öğrenciler de tabiî olarak erkeklerden oluşmuştur. Daha sonraki düzenlemede dört yıllık ortaokul şeklinde de aynı durum devam etmiştir. Ancak ayrıntısı aşağıda görüleceği üzere 1960'tan itibaren yavaş yavaş kız öğrencilerin bu kurumlarda eğitim görmeye başladıkları tespit edilmektedir. Ancak 12 Mart 1971 muhtırası sonrasında İmam Hatip yönetmeliğinin

16 Mustafa Öcal, Bozok Imam Hatip Mektebinden Yozgat İmam Hatip Liselerine, Bursa 2015, s. 134. 
eğitim ve öğretimle ilgili maddesinin bu faaliyet alanının yalnızca erkeklere has olması şeklinde düzenlenmesi, o dönemde izah edilemeyen pek çok konudan birini oluşturmaktadır. Nitekim bu sırada İmam Hatip okullarına bakıldığında az da olsa kız öğrenci bulunduğu dikkati çekmektedir. Yönetmelikten hareketle bu öğrencilerin kayıtları silinmese de yeni kayıtların alınması ve orta kısmı bitirenlerin liseye kayıt yaptırmaları engellenmiştir.

Dolayısıyla İmam Hatip liselerinde kız öğrencilerin okuyabilme fırsatı 1976'dan sonra normalleşme zeminine ulaşmıştır. Bütün bu gelişmeler olurken İmam Hatip okullarına kız öğrencilerin ne zaman ve hangi şartlarda kayıt yaptırdıklarına bakıldığında 1960'lı yıllara gitmek gerekmektedir. Mekân olarak baktığımızda da karşımıza Yozgat, Antalya, Gaziantep, Afyon, Isparta, Denizli, Kayseri, Siirt ve Çorum illeri çıkmaktadır. Sırasıyla söz konusu illerdeki okullar tanıklarından alınan bilgi çerçevesinde incelendiğinde hepsinin bir birinden farklı hikâyelerinin bulunduğu dikkati çekmektedir. Ancak aradan yarım asırlık zaman diliminin geçmesi bu konudaki canlı bilgi kaynaklarının azalmasına sebebiyet vermektedir. Konuya dair bilgilere ulaşılsa da bütün boyutları ve ayrıntısıyla daha derin analiz yapabilmek için araştırılmaların arttırılmasına ve derinleştirilmesine ihtiyaç hissedilmektedir. İlk sıradaki Yozgat'a baktığımızda yolumuzun Ankara İlahiyat Fakültesi mezunlarıyla kesiştiğini görürüz. 1960 yılı söz konusu Fakülte’den mezun olan üç kızdan ikisinin öğretmen olarak atamasının yapıldığı yıllara denk gelmektedir. Bu yıl (Prof. Dr.) Beyza Bilgin Yozgat İmam Hatip Okulu’na, diğer arkadaşı Aysel Baranok (Ayas) da Antalya İmam Hatip Okulu’na öğretmen olarak atanır. Böylece 1960 yılında iki İlahiyat mezunu kız, ilk defa İmam Hatip Okulunda öğretmenlik yapmaya başlarlar. Bu gelişme bu ylllardan itibaren kız öğrencilerin bu okullarda okuma taleplerinin ortaya çıkmasına sebebiyet verir. Nitekim Yozgat'ta okula bayan meslek dersi hocasının geleceğinin haberinin duyulması, okulda hareketliliğe sebebiyet vermiş olmalı ki kız öğrencilerin bu okullara gitmemesinin bir eksiklik olduğu anlayışı doğmuş ve bu amaçla konu hem gündeme taşınmış, hem de veliler okul idaresinden bu yönde talepte bulunmuşlardır. ${ }^{17} \mathrm{Bu}$ sırada velilerin hareket noktası diğer ortaokul ve liselere kız öğrenciler gittiği gibi bu okullara da gitmeli ilkesine dayanmaktadır. Böylece Türkiye’de ilk defa dînî hassasiyete sahip muhâfazakâr kesimin kızlarının hem lise seviyesinde tahsil almaları, hem de resmî anlamda dini eğitimi almaları gerçekleşmiş olacaktır. Okul kayıt defterinde yapılan incelemelere göre 1960-1961 öğrenim yılında Memduha Akyol ve Leyla Yortanlıoğlu, bir sonraki sene de (1961/1962) Mevlüde Akyol ile Gülseren Ertek okula kayıt yaptırırlar. Ancak bu kızların her biri iki yıl sonra okuldan ayrılırlar, dolayısıyla kızlar mezun olmamakla birlikte bir ilki gerçekleştirirler. ${ }^{18}$

17 Söz konusu eğitimin başlamasına dolaylı olarak vesile olan Beyza Bilgin mesele hakkında şunları belirtmektedir: Kızlar benden önce değil benimle birlikte, ancak benim teşvikim olmadan bana özenerek okula kayıt oldular. Okula bayan meslek dersleri öğretmeni tayin olunca bazı veliler biz de kızlarımızı gönderelim, okusunlar, öğretmen olsunlar teklifinde bulunarak okula müracaat etmişler. Bunun üzerine okulun meslek okulu olduğu, imam ve hatipliğin erkek mesleği olduğu söylenerek velilere kızların okula alınmalarının uygun olmayacağı söylenmiştir. Ancak veliler ısrarlarını sürdürerek “İmam Hatip Okullarında sadece imam ve hatipler değil Kur’an kursu öğretmenlerinin de yetiştiğini ve kızların da Kư’an kursu öğretmeni olabileceğini” ileri sürmüşler. Bunun üzerine yazılmış, çizilmiş, araştırılmış, mevzuatta okula kızların alınmayacağına dair kayıt bulunamadığından o yıl kız öğrenci kaydı yapılmıștır (geniş bilgi için bk. Öcal, Bozok İmam Hatip, s. 196).

18 Söz konusu bilgiler Aralık 2015 ve Ocak 2016’da Yrd. Doç. Dr. Mustafa Öcal ile yapılan görüşmeler sonunda onun konuyla ilgili çalışmalarından ve kendisinden elde edilen şifahî bilgilerden derlenmiştir. İsmi geçen kızlarla ilgili iletişim bilgilerine ulaşılamadığından görüşme fırsatı elde edilememiştir. 
Diğer örneklere geçmeden önce burada bir noktanın altının çizilmesinden fayda vardır. Kız öğrencilerin İmam Hatip okullarına gitmeye başlaması meselesini konu edinen bizden önce hiçbir çalışmanın yapılmaması, bu konuda yorum yapmayı zorlaştırmaktadır. Biz elde ettiğimiz verilerden hareketle meselenin tasviriyle ilgili şunları söyleyebiliriz: Yozgat dışında ilk öğrenci ne zaman alınmıştır diye sorduğumuzda birden farklı okula bakmamız ve ilkleri değişik kategoriler çerçevesinde incelememiz gerekmektedir. Meselâ ilk müstakil kız sınıfı açanlar Isparta ve Denizli İmam Hatip Okulu’yken ilk kız okulu sayılabilecek teşebbüs Çorum İmam Hatip Okulu’nda yaşanmıştır. Ancak ilk İmam Hatip’ten mezun olan kimdir? diye sorduğumuzda Antalya ve Gaziantep İmam Hatip okulları karşımıza çıkmaktadır. Aynı yıllarda Hatice Erdem'in (Kuru) (1962/1963) Antalya, Fatma Zehra Kanlı'nın da, (Küçüköztaş) (1963/1964) Gaziantep İmam Hatip Okulu’na tek öğrenci olarak kayıt yaptırdıkları dikkati çekmektedir. Başlangıçta Antalya'daki okul idaresi muhtemelen olaya sıcak bakmamış olmalı ki öğrencinin babası Yusuf Erdem dönemin Din Eğitimi Genel Müdürü Kemal Edip Kürkçüoğlu ile Milli Eğitim Bakanlığı’na müracaat etmiştir. Nitekim Milli Eğitim Bakanı adına müsteşar Mehmet Arslantürk, Yusuf Erdem'in kızının Antalya İmam Hatip Okulu'na gitmesi hususunda herhangi bir sakınca olmadığını ifade eden bir cevap yazmıştır. ${ }^{19}$ Hatice Erdem'le yaptığımız görüşmeler sırasında babasının aslında çok bilgisi olmayan, hatta okuma yazma bilmeyen bir zat olmakla birlikte o sırada Kavaklı Mescit Cami imamının teşvik ve yardımları sayesinde dilekçeleri yazdırdığını öğrendik. Bundan başka Hatice Erdem'in okul yıllarında örnek aldığı ve desteklerini gördügü öğretmenleri arasında, daha sonraki yıllarda İlahiyat fakültelerinde akademik hayata katılan (Prof. Dr.) Avni İlhan, (Prof. Dr.) Rami Ayas ile Aysel Ayas ve (Prof. Dr.) Erdoğan Fırat ile Gülser Firat gibi isimlere rastlanmaktadır. Ancak okula başladığı zaman ifadesinden anlaşıldığı üzere kendisini bilinçli bir din eğitimi öğrencisi olarak hissetmediğinden başını ya örtmemiş ya da mendil gibi bir örtü kullanmıștır. Daha sonra üçüncü sınıftayken hocası Gülser Fırat'ın ve üst sınıftaki öğrencilerin teşvikiyle kendisini daha bilinçli bir öğrenci olarak hissetmeye başladığını ve başını örttüğünü gündeme getirmektedir. Bu şekildeki kız öğrenci alımı daha sonraki yıllarda da devam etmiş, bir sonraki yıl 1 öğrenci 1965-1966'da, 2 kız öğrenci daha okula kayıt yaptırmıştır. Nitekim 1972-1973'te mezun olan kızlardan Muazzez Uysal (Yllmaz) ile Fatma Çetin (Koç) İzmir Yüksek İslâm Enstitüsü’ne devam etmişler ve onlar da İzmir Yüksek İslâm Enstitüsü’nün mezun ettiği ilk kız öğrencileri arasında yer almışlardır. ${ }^{20}$

Antalya İmam Hatip Okulu’nda kız öğrencilerin okumaya başlaması tamamıyla kişisel destek ve imkânlarla hayata geçmiş görünmektedir. Benzer duruma Gaziantep İmam Hatip Okulu’nda da rastlanmaktadır. Ancak bu öğrenci vefat ettiğinden kızı ve eşinden aldığımız kısıtlı bilgilerle araştırmamıza devam ettik. Fatma Zehra Kanlının okula kayıt yaptırma talebinin dedesinden geldiği tespit edilmektedir. Böylece iki farklı okula da ilk defa kız öğrenciler başlarken bir birinden haberlerinin olmadıkları ve velilerinin talepleriyle müracaat

19 Yusuf Erdem'in 8 Şubat 1962'de Din Eğitimi Genel Müdürlüğüne, 5 Mayıs 1962'de Millî Eğitim Bakanlığı’na müracaat ettiği, öğrencinin dosyasındaki dilekçelerden anlaşılmaktadır. 5 Haziran 1962'de Millî Eğitim Bakanlığ1 söz konusu dilekçelere Yusuf Erdem’in kızının ilkokul diplomasıyla Antalya İmam Hatip Okuluna başvurduğu takdirde kayıt yaptırabileceği cevabını vermiştir (dilekçe ve evraklara ulaşmamızda bize yardımlarını esirgemeyen Antalya İmam Hatip Lisesi Müdürü Osman Musara’ya teşekkür ederiz).

20 Hatice Erdem ve Muazzez Uysal yanında Prof. Dr. Avni İlhan, Prof. Dr. Rami Ayas ve Aysel Ayas ile Gülsel Firat'la Ocak ve Şubat 2016'da meselenin akışına göre müteaddit defalar görüşülüp okulun ilk günleri ve ortamı hakkında bilgi alınmıştır. Her birine paylaşımlarından ötürü müteşekkiriz. 
ettikleri anlaşılmaktadır. Söz konusu talebin altında da öğrencilerin okuldaki eğitim sayesinde ahlaklı ve dindar olmalarını temin etmek amacının bulunduğu ve her iki velinin de bunu sağlamak amacıyla şartları zorlayarak kızlarını okula kaydettirdikleri görülmektedir. O yıllarda Gaziantep İmam Hatip Okulu’nun kurucu müdürünün Rami Ayas olması, onun da Antalya'dan buraya gelmesi, benzer izin işlemlerine ihtiyaç hissetmeden kız öğrenci aldığını akla getirmektedir. Nitekim eşi Aysel Ayas’ın da meslek dersleri öğretmeni olması olayın desteklenmesine sebebiyet vermiş görünmektedir. Böylece 1970 yılının Haziran ayında ilk defa Fatma Zehra Kanlı'nın ${ }^{21}$ Eylül ayında da ikinci olarak Hatice Erdem'in Burdur'dan mezun olduğuna şahit olmaktayız. Antalya İmam Hatip Okulu’nda öğretmenlik yapan (1964-1965) Erdoğan Fırat ile eşi Gülser Fırat’ın tayinlerinin Afyon Karahisar’a çıkmasını müteakip orada da yeni bir okul tecrübesine daha rastlanmaktadır. Gülser Fırat Ankara Üniversitesi İlahiyat Fakültesi'nden mezun (1963-1964) olduktan sonra tayini önce Antalya'ya oradan da Afyon'a çıkmıştır. O bir yandan Afyon Kız Enstitüsü’nde öğretmenlik yaparken diğer yandan da Erdoğan Fırat'ın müdür yardımcısı olduğu Afyon İmam Hatip Okulu’na kız öğrenci alınmasını destekleyip önayak olmuştur. Böylece Afyon İmam Hatip Okulu 1966/1967'de diğer okullardan farklı olarak sadece erkek öğrenciyle değil de hem kız hem de erkek öğrenciyle eğitim hayatına başlamıştır. ${ }^{22}$ Aşağıda ayrıntısıyla incelenecek olan Isparta İmam Hatip Okulu da 1966/1967'de müstakil sınıf olarak kız öğrenci alan okullar arasında bulunmaktadır. Diğer bir tecrübe de 32 kişilik kız öğrenci sınıfıyla Denizli İmam Hatip Okulu’nda (1968/1969) gerçekleşmiştir. ${ }^{23}$ Aynı yıl Kayseri’de de 3 kız öğrencinin (Melike Nur ve Melike Nuran Karakılıç ile Ayşe Güneş) kayıt yaptırdığı görülmektedir. Bunlardan ikisi Ankara İlahiyat Fakültesi mezunu meslek dersi öğretmeni Celalettin ve Saadet Karakılıç’ın kızlarıdır. Diğer öğrenci de yine bir meslek dersi öğretmeni Mustafa Güneş’in kızıdır. Ancak Mustafa Güneş Siirt İmam Hatip Lisesi kurucu müdür olunca Ayşe Güneş eğitimine burada okulun ilk kız talebesi olarak devam eder. 1972'de Ayşe Güneş Siirt, Melike Nur ile Melike Nuran da Kayseri İmam Hatip Ortaokulu’ndan mezun olurlar. Melike Nur ile Melike Nuran 1975'de lise kısmından mezun oldukları halde Ayşe Güneş'in babasının Siirt'ten başka bir yere tayini çıktığından ve şu anda vefat etmiş olduğundan lise kısmına devam edip etmediği bilgisine ulaşamadık. ${ }^{24}$

21 Şubat 2016'da Fatma Zehra Kanlı’nın kızı ve Gaziantep Mehmet Hayri Akınal Kız İmam Hatip Lisesi müdürü İsmail Bozo yanında müdür yardımcısı Mesut Selli'yle görüşülüp hem onun okula girişiyle ilgili evraklara hem de bilgilere ulaşılmaya çalışılmıştır. Aynı bilgileri takip etmek amacıyla Fatma Zehra Kanlı’nın Konya Yüksek İslâm Enstitüsündeki kaydı ve mezuniyetiyle ilgili evraklar da temin edilmiştir. Bundan başka Fatma Zehra Kanlı’nın okula başladığı zamanlarda okul müdür olan Prof. Dr. Rami Ayas ile eşi Aysel Aras (geniş bilgi için bk. Türk Din sosyolojisinde Mehmet Rami Ayas, İstanbul 2012, s. 63) ve aynı tarihlerde okulda öğrenci olup şimdi emekli öğretmenler arasında bulunan Celal Kara ile görüşülüp dönemin şartları ve atmosferi hakkında bilgi alınmıştır Bu konuda paylaşımda bulunanların her birine müteşekkiriz.

22 Ocak 2016'da Gülser Firat ile görüşülüp hem Antalya İmam Hatip Okulu hem de Afyon İmam Hatip Okulu’nun atmosferi hakkında bilgi alınmıştır. Mevcut bilgilerden ötürü kendisine müteşekkiriz.

23 Şu andaki Denizli İmam Hatip müdürüyle görüşülmüş ve ilk öğrencilerin sayısıyla ilgili malumata ulaşılmıştır. Ancak kız öğrencilerin ilk defa alındığı ve Isparta İmam Hatip Okulu’ndan başörtüsünden dolayı tasdiknameyle öğrencilerin geldiği zaman müdür olan Mehmet Kaya vefat ettiğinden okulun o dönemki uygulamaları ve atmosferi hakkında yeterli bilgiye ulaşılamamıştır.

24 O zamanki Kayseri İmam Hatip Okulu şimdi Kayseri Kız İmam Hatip Lisesi olmuştur. Şubat 2016'da müdür ve müdür yardımcılarıyla görüşülerek ilk öğrenciler hakkındaki bilgilere ulaşılmıştır. Her birine paylaşımlarından ötürü müteşekkiriz. 
Müstakil kız öğrenci sınıfı şeklindeki öğrenci alımı şimdiki verilerimize göre ilk defa Isparta İmam Hatip Okulu'nda gerçekleşmiştir. İlk yedi İmam Hatip Okulu arasında bulunan Isparta'da sürecin gelişmesine öncülük yapan isimlerin başında Ankara Üniversitesi İlahiyat Fakültesi’nden mezun olan Yusuf Kenan Karahan (1964/1965) ile Dursun Ayvaz (1963/1964) vardır. Onların -aşağıda anlatılacak- Çorum İmam Hatip Lisesi’ndekine benzer faktörlerden hareketle böyle bir teşebbüse giriştikleri anlaşılmaktadır. Ankara Üniversitesi İlahiyat Fakültesi'nin sevilen hocaları arasında bulunan Prof. Dr. Tayyib Okiç'in Komünizm'e karşı direnmenin yolunun din eğitiminden geçtiğini ifade etmesi ve bu konularda öğrencilerini teşvik etmesi yeni mezun öğretmenlerin bu olaya girişmelerine vesile olmuştur. Söz konusu öneri ve teşvikler neticesinde, onlar 1966/1967’de Isparta İmam Hatip Okulu’na kız öğrenci alımını sağlamışlardır. O yıl 44 kişiden oluşan müstakil kız sınıfıyla eğitime başlanır, 4 yıllık orta kısmından 18 kişi mezun olur. Hatta ilk defa diğer il ve ilçelerden de gelen öğrencilerin ikametlerini temin etmek amacıyla öğrencilere yurt imkânları da sağlanır. O dönem okulun müdürü Zafer Kızıldağ’ır. Kız öğrencilerin okula başlamalarına zemin hazırlayan şartlar araştırıldığında müdürleri Zafer Kızıldağ ve Isparta İl Milli Eğitim Müdürü Sadık Güneş'in devrin başbakanı Süleyman Demirel'le akrabalıklarının bulunması dikkati çekmektedir. Ancak söz konusu akrabalık ilişkileri meseleyi kolaylaştırmaktan ziyade okulun mevcut durumunu güçlendiren etkenler arasında sayılmaya daha müsait görünmektedir. Yaptığımız görüşmelerden edindiğimiz intiba, müdür ve Milli Eğitim müdürünün doğrudan meseleyi kolaylaştırdıklarından söz etmek mümkün olmasa da ilk sayılabilecek teşebbüsün olağan şartlarda gerçekleşmesini sağladıkları anlaşılmaktadır. Ancak kız öğrencilerin okula başlamaları, başörtüsü takmalarından ötürü başta ihtilal dönemleri olmak üzere sık sık Atatürk ilke ve inkılâplarına zarar vereceği gerekçesiyle gündemin ilk sıralarında yer almıştır. Kız öğrenciler okula başladıklarında orta öğretimdeki şapka takma uygulamasından ötürü şeridi beyaz şapka kullanmışlardır. ${ }^{25}$ Cumhuriyet döneminde dinin kamusal alanda görünür olması meselesi, büyük bir problem olduğundan kız öğrencilerin okulda başlarını örtmesi de yakın zamana kadar aşılması gereken en ciddî meselelerden biri olarak devam etmiştir. Öğrencilerin Kur'ân-1 Kerîm dersi yanında meslek derslerinde yada tüm derslerde başlarını örtmek istemeleri, Cumhuriyet' in Batılılaşma ya da modernleşme tecrübesine aykırı bir durum olarak görünmüştür. Nitekim hemen tüm İmam Hatip Okulu bu problemle yüzleşerek büyük baskılara maruz kalmıştır. Bu amaçla öğrenciler bireysel hakları ve dinî anlayışlarından dolayı meseleyi çözme amacıyla gerektiğinde yanlarında taşıdıkları şapkalarını başörtülerinin üstüne takmak gibi yöntemlerle örtülerini gizleme yoluna gitmişlerdir. $\mathrm{Bu}$ amaçla öğrenciler örtülü kalmayı sağlamak amacıyla birbirinden değişik yollarla meseleyi çözmeye çalışmışlardır. Meselâ başörtüsüne yalnızca Kur'ân-1 Kerim dersinde müsaade edilmesine karşlık, hocaların diğer derslerde de öğrencilerin başlarını örtmek amacıyla tahtaya dersle alakalı âyetler yazması bunlardan biridir. Diğer bir yöntem de geleneksel örtüyle yeni tarz başörtüsünün bir birinden farklı olması şeklindeki söyleme dayanmaktadır. Geleneksel ve yerel örtüler masum kabul edilirken yeni tarz başörtüsü Atatürk ilke ve inkılâplarına karşı

25 Şapka kanunun yaygınlaşması ve toplumsal değişimi sağlaması amacından hareketle uygulamaya konduğu düşünülen orta öğretim kurumlarında şapka giyme uygulaması 1970 yılında yürürlükten kalkmıştır. Nitekim bugünden geriye gidildiğinde liselerin arşivlerinde bu durumun belgeleriyle karşılaşıldığı gibi o dönemin öğrencileri de konuya tanıklık etmektedirler (geniş bilgi için bk. Öcal, Bozok İmam Hatip Okulu, s. 136; http://www. buyuktorbali.com/lisede-sapkali-ogrenciler/ 13,12,2016). 
gelmek olarak değerlendirilmektedir. Isparta İmam Hatip Okulu’nda o dönemlerde Türkçe öğretmenleri öğrencilerin başörtüsüne değil de geleneksel beyaz tülbente izin vermesi, bu durumun uygulamalarından diğer birini oluşturmaktadır. ${ }^{26}$ Dolayısıyla başörtüsü yasağ 1 öğrencilerin gerek okul gerekse de çalışma hayatı boyunca sık sık karşılarına çıarılan ve rejime karşı gelme unsuru olarak kullanılan bir esas olarak uzun süre gündemde kalmıştır. Nitekim Isparta İmam Hatip Okulu’nun öğrencileri de Kur’an-1 Kerîm derslerinde başlarını örttükleri gibi diğer derslerde de örtmek isteyince olay büyüyüp disiplin suçuna dönüşmüştür. Veliler bu meseleyi çözmek amacıyla hemşehrileri dönemin Başbakanı Süleyman Demirel'e gitmenin etkili bir yol olacağını düşünürler. Ancak bu teşebbüsleri meselenin çözülmesi şöyle dursun -öğrencilerin deyimiyle- ters teperek yasağın şiddetlenmesine zemin hazırlamıştır. Olayı yakından incelediğimizde 26 Aralık 1970 tarihli İstiklal Marşı törenine bakmamız gerekmektedir. Hâdise, sabah törende okul bahçesinde beşinci sınıf öğrencisi Şüheda Bede’nin (Akşit) örtüsünü arkadan çeken bir öğretmenin teşebbüsüyle meydana gelir. Öğrencinin başını doğal olarak açmak istememesinden ötürü duruma insiyakî olarak vermiş olduğu tepki, öğretmenin de başörtüsünü çekmeye devam etmesi neticesinde olay, başörtüsünün yırtılmasıyla sonuçlanır. Bu hadiseler 1971 muhtırası arefesinde gerçekleştiğinden dönemin Başbakanı Süleyman Demirel’e yakınlığıyla bilinen kimselerin konuya müdahil olup "mesele ivedilikle çözülecektir" şeklindeki vaatlerde bulunmalarına rağmen gerçekleşme zemini bulamaz. Öğrenciler de 1971 yılı bahar döneminde derslere başları örtülü olarak girmeye başlarlar. Ancak bütün bu olayların muhtıra dönemine denk gelmesi, hem idare hem de öğrenciler açısından zor bir sürecin varlığını göstermektedir. Muhtemelen baskılardan ötürü söz konusu hadiseler normal standartta değerlendirilemeyip suç kabul edilerek öğrencilerin mükerreren disipline sevk edilmelerine, hatta on öğrencinin cezalandırılarak tasdiknameyle Denizlìye uzaklaştırılmasına sebebiyet verir. Nitekim 1971 muhtırası sonrasında, İmam Hatip okullarının orta kısımlarının kapanması ve 1972'de “erkek olmak" şartının getirilmesi gibi hususlar hatırlanırsa bu dönemdeki müdahalenin ve baskının varlığ kendiliğinden anlaşılabilir. Bu durum eğitimin yasakların gölgesinde devam etmesine sebebiyet verdiğinden hem eğitim seviyesini düşürmüş hem de normal bir eğitim süreci yaşanmasını imkânsız kılmıştır. Lise kısmına 18 kişi olarak başlayan öğrencilerden ikisi 5. sınıfın sonunda tasdiknameyle uzaklaştırılınca sonunda okulu bitirenler 4 kişiden ibaret kalmıştır. ${ }^{27}$ Başörtüsü yasağının uzantısında gündeme

26 Başörtüsü yasağı dönemlerinde yukarıda müracaat edilen yöntemlerin hemen hepsinin buna maruz kalan öğrenciler tarafından kullanıldığı, maalesef tarihe kayıt düşülmesi gereken hususlardandır. Bendeniz de eğitim ve hatta çalışma hayatı boyunca yaşadığı problemlerde bu yollardan hemen her birini hayatının değişik kademelerindeki yasakları aşmak amacıyla uygulamak zorunda kalmış mağdurlardan biriyim. Başörtüsü üzerine takılan şapkalar 28 Şubat sürecinde Marmara Üniversitesi İlahiyat Fakültesi’nde kızlarının mâkus talihini oluşturmuştur. Yine bu meselenin halledilmesi için öğrencilerin başlarını kazımaları, peruk takmaları, peruk üstüne şapka takmaları gibi yöntemlere müracaat etmeleri, bu meseleye yönelik geçici çözümlerden bazılarıdır. Başörtüsü yasağının uygulamaya konmaya başlamasıyla beden eğitimi derslerine erkek öğretmenlerin gelmesi ve resmî geçit törenlerine iştirak mecburiyeti gibi silsile halindeki uygulamalar da, öğrencilerin maruz kaldığ 1 ve aşmakta zorlandığı durumlardır. Bu sırada öğrencilerin kendilerini bu tür uygulamalardan muaf tutabilmek amacıyla sıklıkla başvurdukları yollardan biri de sağlık raporu almak şeklindeki çözüm arayışlarıdır. Ancak orta öğretim sırasında bu durumla karşılaşan iki kız kardeş olarak biz, çok zorlandığımız ve çözüme ulaşamadığımız anları da yaşamak durumunda kaldığımızı hatırlarız. Bunlardan biri rapor almakta mahir olan babamın çözümsüz kaldığı bir anda kız kardeşimin sağlam dişini çektirmek zorunda kalmasıdır. Yani bana rapor aldığı halde ona rapor alamamasına karşılık kardeşimin dişini çektirerek rapor almak durumunda kalması, eğitim ve başörtüsü arasında sıkışan öğrencilerin yaşadıkları travmalardan birine örnektir.

27 Aralık 2015 ve Ocak 2016'da Isparta İmam Hatip Lisesi’yle ilgili malumatı elde etmede ilk kız öğrenciler arasında 
gelen diğer bir konu da kız öğrencilerin millî bayramlardaki geçit törenlerine ve özellikle 19 Mayıs Gençlik ve Spor Bayramı’na katılıp katılmamalarıyla ilgilidir. Bu husus özellikle ihtilal veya muhtıra sonrasında ana gündem maddesi haline geldiğinden hem ilin mülkî ve idarî erkânı hem de Millî Eğitim Müdürlüğü̉nü ilgilendiren bir konu olur ve bundan ötürü okullara yönelik takibat ve denetimler arttırılır.

Kaydedilmesi gereken diğer bir tecrübe de Çorum İmam Hatip Okulu’nda yaşanmıştır. Okul müdürü (Prof. Dr.) Halis Ayhan iki sınıf olarak 69 kişiden oluşan kız öğrenciyle (1969/1970) ders dönemine başlar. Çorum’un Isparta ve Denizli’den farkı, kızların müstakil binada eğitim hayatına girmeleri şeklinde olmuştur. Böyle bir tercihin temelinde erkek öğrencilerin bulunduğu okulun fizikî şartlarının kız öğrencilerin okumasına müsait olmaması durumu vardır. Dolayısıyla öğrenciler o dönemde Kur'an kursu olarak yapılmış ancak öğrencisi bulunmayan Hıdırlık mevkiindeki binada öğrenimlerine başlarlar. Kursun öğrenci almaya başlamasından sonraki yıllarda da müftülük binasının bir kısmında eğitimlerini devam ettirirler. Okulun kız öğrenci alması hikâyesini araştırdığımızda hazırlık aşamasında il genelinde bir anlamda seferberlik ilanı gibi çalışma yapıldığı bilgisine ulaşılmaktadır. Şehrin önde gelen saygın, dinî konularda rehberliğine müracaat edilecek kişileri yanında zengin işadamları ve esnafı ile siyasî kimliğe sahip ve gerektiğinde devlet erkânıyla işbirliği yapabilecek kimselerin hepsinin bu meseleye katkı sağladıkları ve okul aile birliği içinde etkin rol üstlendikleri görülmektedir.

Halis Ayhan’ın müdür olarak bu teşebbüsünde en büyük faktörün Isparta İmam Hatip Okulu'yla aynı olduğu anlaşılmaktadır. Türkiye'deki İlahiyat tahsilinde önemli katkıları bulunan Prof. Dr. Tayyib Okiç’in ders ve sohbetleriyle dönemin dinî entelektüel atmosferine de katkıda bulunduğu ortaya çıkmaktadır. Nitekim onun sohbetlerindeki konulardan biri de kız öğrencilerin din eğitimi imkânlarından faydalanması gereğine yaptığı vurgudur. Bu tezini temellendirirken o, kendisi Boşnak olduğundan Balkanlar'dan örnek verir. Kız öğrenciler Bulgaristan'daki medreselerde eğitim imkânlarından faydalanmadıkları halde Boşnaklar'da ise tam tersine öğrenci olmuşlardır. Bu durum Balkanlar'daki bu iki bölgenin kaderinin bir birinden farklı olmasına zemin hazırlamıștır. Bundan ötürü Boşnaklar uzun süreli savaş yıllarında kadınların katkısıyla Materyalizm'in negatif etkilerini asgari düzeye indirgeyerek toplumun dindar kalmasını sağlamışlardır. Özellikle erkeklerin toplumsal hayata katılamadığı savaş gibi zamanlarda kadınlar hem evde çocukların yetişmesini, hem de eğitim kurumlarında eğitim faaliyetlerinin sürdürülmesini sağlamışlardır. Böylece toplumun temel dinamiği olan din bölgede kesintiye uğramaksızın hayatiyetini sürdürmüştür. Yine Tayyib Okiç İlahiyat Fakültesi’nde okuyan kız öğrencilerin başlarının açık olmasını eleştirenleri doğru bulmadığını ve bunun yerinde bir eleştiri olmadığını şu şekilde ifade eder:

\footnotetext{
bulunan Gülnur Terlemez (Kazııı), Yadigâr Kalaycı (Büyükkapusuz), Emine Dal (Çalışkan), Şüheda Bede (Akșit) ve emekli Denizli İmam Hatip Lisesi Müdürü Halil Gencoğlu’yla o dönemde öğrenci ve eski İmam Hatip Lisesi Koruma Derneği Başkanlığı yapan Ali İhsan Altınok'la müteaddit defa görüşmeler yapılmıştır. O dönemde okula kız öğrenci alınmasında öncülük yapan Yusuf Kenan Karahan ile görüşülerek okulun atmosferi ve yaşanan sıkıntılarla ilgili yeterli bilgi elde edildiği halde bu konuda etkin diğer önemli bir isim olan Dursun Ayvaża ulaşılamamıștır. Konuyla alakalı olarak okul müdürü ve müdür yardımcılarına da müracaat edilmiş olmakla birlikte okul kayıt ve kütük defterleri kullanıma müsait olmamasından ötürü resmî belgeler elde edilememiştir.
} 
Kız öğrenciler Hukuk ve Tıp fakültelerinde başları açık olarak okumaları eleştirilmiyorsa İlahiyat Fakültesi’nde de eleştiri konusu olmamalıdır. Çünkü onlar burada değil de başka bir yerde olsalardı aynı şekilde başları açık olarak okuyacaklardı, İlahiyat Fakültesi’nde okumalarının ise toplumun dinî hayatına katkı sağlayacağı şüphesizdir. Onun bu tavrı sergilemesinin altında, İslâm'da baş örtme vecibesi olmadığı șeklindeki bir düşünce yoktur. Çünkü o, Ankara Üniversitesi İlahiyat Fakültesi’ndeki başörtüsü yasağında Hatice Babacan’nn haklı olduğunu savunan isimler arasında yer almıştır. Olay, Fakülte profesörler kuruluna nakledilince Okiç onun bu eyleminin suç olmadığını söyleyen ve cezalandırılmasını doğru bulmayan isimler arasında yer almıştır. Ancak hocanın bu tutumu, o dönemde Fakülte idaresi tarafından pek olumlu karşılanmamış olmalı ki 1968'de hukuka aykırı olarak sözleşmesi yenilenmemiștir. Bu gelişmeler üzerine o, Erzurum’a geçerek maddi zorluklar altında hayatını devam ettirmiş ve kısa bir süre sonra da (1977) vefat etmiştir.

Aslında aşağıda müstakil başlık altında incelenecek olan tesettür konusu kız öğrencilerin başta İmam Hatip liseleri ve İlahiyat fakülteleri olmak üzere eğitim kurumlarına gitmeye başlamalarıyla, hem ciddî bir sorun haline gelmiş, hem de bundan dolayı okullar müdahaleye açı hale gelmiştir. Meselâ Çorum'daki tecrübede okula yapılan müdahalelerden birisi, kızların neden ayrı binalarda okutulduğuna dair bakanlığın yazısında ortaya çıkmaktadır. Aslında illerde eğitim normalde valinin ve Millî Eğitim müdürü arasındaki yazışmalar neticesinde hayata geçtiği halde konu İmam Hatiple ilgili olduğunda devreye Bakanlığın veya ordu komutanının girmesi sık karşılaşılan uygulamalardan biridir. Diğer bir konu da öğrencilerin resmî bayramlardaki geçit törenlerine ve özellikle 19 Mayıs Gençlik ve Spor bayramındaki gösterilere katılmasıyla ilgilidir. Bu konu İmam Hatip Okulu’na giden öğrencilerin hemen hepsinin eğitim hayatında çözüm aranan önemli meseleleri arasında yer almıştır. Bu vesileyle okullar sık sık baskıya maruz kalıp takibata alınmışlardır. Meselâ Çorum İmam Hatip Okulu bir dönemde bu sorunu öğrenci velisi ve Demokrat Parti İl Başkanı Casim Aksakal vasıtasıyla geçici olarak çözüme kavuşturmuştur. ${ }^{28}$

Bütün bu incelemelerimizden İmam Hatip liselerine kız öğrencilerin gitmeye başlamasının 1960 ile 1970 yılları arasına denk geldiği dikkati çekmektedir. Tek tek her okulun hikâyesi bir birinden farklı olmakla birlikte şu anki verilerimizden hareketle bazı ortak noktalarının bulunduğu dikkati çekmektedir. Bunlardan birisi Ankara İlahiyat Fakültesi’ni bitiren öğrencilerin İmam Hatip Okullarında öğretmenliğe başlamaları, bu eksikliğin farkına varılmasına vesile olmuştur. Nitekim hocaların bir kısmı zaman zaman doğrudan ya da dolaylı bu meselenin gündeme gelmesine rehberlik etmişlerdir. Ancak 1976 yllından itibaren okullara kız öğrencilerin gitmesinin daha normal bir zemine kavuşması, hem "erkek olmak" engelinin kalkmasından, hem de 1960 ve 1970 yılları arasındaki parmakla gösterilebilecek sayıdaki nâdir tecrübenin semeresinin görüleceğine döneme rastlamasından kaynaklanmaktadır.

İmam Hatip liselerinin mevcut durum ve yaşadıkları tarihsel tecrübe incelendiğinde onların Cumhuriyet idaresinin halkın ve tabanın isteklerini dikkate alması açısından

28 Çorum İmam Hatip Okuluyla ilgili bilgilere okulun kurucu müdürü olan Prof. Dr. Halis Ayhan'la Şubat 2016'da yapılan görüşme neticesinde elde edilmiştir. Bundan başka yine Feyzullah Kıyıklık, Zöhre Kıyıklık Yılmaz ve Ethem Erkoç’tan okulun ilk atmosferi hakkında bilgi alınmaya çalışılmıştır. O dönemlerdeki ilk kız öğrenciler arasında bulunan Mihriban Aksu (Menekşe) ile de Ocak 2016'da görüşülmüştür. 
araçsal bir konumda bulundukları ve önemli fonksiyonlar icra ettikleri anlaşılmaktadır. Diğer bir ifadeyle okul ve öğrenciler acı ve sancılı süreçlerden geçerek laik siyasal erk ile dindar halk arasındaki mevcut tabuların yıkılmasında önemli rol üstlenmişlerdir. Genelde İmam Hatip liselerinin, özelde kız öğrencilerin İslâmî kimlikleriyle görünür olma talepleri, laik Cumhuriyet rejiminin halkı ve isteklerini dikkate alması açısından hayatî fonksiyon icra etmiştir. Tarihsel süreç bu okulların bir yandan orta öğrenim kurumu olma yolundaki kendi misyonlarını tamamlamalarını sürdürürken diğer yandan da cinsiyet ayrımı gözetilmeksizin tüm öğrencilerin okuyabilecekleri kurumsal bir yapıya ulaşmalarını sağlamıştır. Değişik illerdeki İmam Hatip okulları incelendiğinde bunların her birinin kendi var olma çabaları yanında kızların okuması konusunda birbirinden değişik kesimlerin canla başla çalışarak çok büyük gayretlerle bu konuyu hayata geçirdikleri ortaya çıkmaktadır. Söz konusu desteğin altındaki sebep de ülkede uzun yıllar din eğitimi almanın, hatta Kur'ân-1 Kerîm okumanın önündeki yasağın bu vesileyle kalkacağına olan inançtır. Nitekim İmam Hatip okullarıyla yılların özleminin uygulamaya konacağı düşünüldüğünden halk olaya dört elle sarılarak elinden gelen desteği uygulamaya koymuştur. Aslında kurumların tarihsel tecrübeleri incelendiğinde onlarla ilgili devlet ile halkın aynı noktada durduklarını söylemek imkânsızdır. Ancak halk bu konuyu samimî bir teşebbüs olarak algıladığından ve böyle inandığından içtenlikle hayata geçirmek için uğraşmıştır. Şüphesiz bu sırada örnek olabilecek kimselerin varlığ 1 , Ankara Üniversitesi İlahiyat Fakültesỉnden mezun olan kız öğrencilerin 1960’tan sonra bu okullara öğretmenlik yapmaya başlamalarıyla kısmen halledilmiştir. Ancak zaman zaman bu öğretmenlerin kılık kıyafet tercihlerinden veya dinî bilgilerinin yetersiz bulunması gibi sebeplerden alternatifinin yetiştirilmesi fikri de beraberinde gelişmiştir.

\section{5. İlahiyat Fakültelerinin Tarihçesi}

Bugünkü İlâhiyat fakültelerinin uzun bir tarihi geçmişi vardır. Hatta bunu Cumhuriyet dönemi ve öncesi olmak üzere iki bölümde incelemek mümkündür. Cumhuriyet öncesi dönemin kuruluşunu, 1 Eylül 1900 tarihinde İstanbul'da açılan Dârülfünûn-1 Şâhâne'deki Ulûm-i Âliye-i Dîniyye Şubesi'yle başlatmak mümkündür. 1908'de Meşrutiyetin ilanından sonra büyük ölçüde değişikliğe uğrayan Dârülfünûn-1 Şâhâne’nin adı önce Dârülfünûn-1 Osmânîye, 1913’ten itibaren de İstanbul Dârülfünûnu’na dönüştürülmüş, Ulûm-i Âliye-i Dîniyye Şubesi’nin adı da Ulûm-i Şer'iyye olmuştur. 18 Eylül 1914’teki medreselerin 1slahı sırasında Selimiye Camii avlusundaki I. Abdülhamid Medresesi’nde Medresetü’lmütehassısîn açılmış ve Dârülfünûn bünyesindeki Ulûm-i Şer iyye Şubesi kapatılmıştır. Şeyhülislâmlığa bağlanan Medresetü'l-mütehassısîn 1918'den itibaren tedrise Süleymaniye Medresesi adıyla devam etmiş olup Süleymaniye Medresesi de, 3 Mart 1924'te çıkarılan 430 sayılı Tevhîd-i Tedrîsat Kanunu’ndan sonra çift başlılığa engel olmak amacıyla kapatılmıştır. ${ }^{29}$

29 Halis Ayhan, “İlahiyat”, DİA, XXII, 70-71. Ancak ilginçtir ki kanunun çıtı̆̆ı tarihte 429 İlmiye Medresesi, 33 Dârülhilafe medresesi, buralarda 18 bin öğrenci varken ortaokul ve liselerde yaklaşı 7 bin, yüksek öğrenimde ise 3 bin dolayında öğrencinin kayıtlı olduğu bilgisine ulaşılmaktadır (geniş bilgi için bk. Veli Öztürk, "İlahiyat Fakülteleri ile Diyanet İşleri Başkanlığı ve Millî Eğitim Bakanlığı Arasındaki İlişkilerin Tarihî Gelişimi Bağlamında Bazı Çözüm Önerileri”, Türkiye’de Yüksek Din Eğitiminin Sorunları, Yeniden Yapılanması ve Geleceği Sempozyumu, Isparta 2004, s. 107). 
Süleymaniye Medresesi’nin kapatılmasından sonra Türkiye Büyük Millet Meclisi kanun layihasını tekrar müzakereye almış 21 Nisan 1924'te kabul ve tasdik edilen yeni kanunla İstanbul Darülfünûnu’nun Tip, Hukuk, Edebiyat, İlahiyat ve Fen fakültelerinden müteşekkil olduğu ifade edilmiştir. Böylece daha önceki Şerî̀ İlimler Şubesi yerine İlahiyat Fakültesi açılmıştır. Bundan yaklaşık dokuz yıl sonra 3 Mart 1933’teki Üniversite reformuyla Dârülfünûn lağvedilerek yerine İstanbul Üniversitesi kurulmuş, ancak bünyesinde İlahiyat Fakültesỉne yer verilmemiştir. Bunun yerine Edebiyat Fakültesi’ne bağll "İslâmî Tetkikler Enstitüsü” kurulmuştur. Öğrencisi olmayan Enstitünün öğretim kadrosundaki Şerafettin Yaltkaya Diyanet İşleri reisliğine tayin edilmiş, Mehmet Ali Ayni ile Baki Beyler de emekliye ayrılmışlardır. Enstitü ise talebe yokluğu ileri sürülerek ve iki doçentin de lise felsefe öğretmenliğine nakledilmelerinden sonra 1936'da lağvedilmiştir. Bu gelişmeler Cumhuriyet'in başlangıcında din eğitimi kurumlarının hemen her ikisinin de ömürlerinin kısa olduğunu ortaya koymaktadır.

Burada Tevhîd-i Tedrîsat Kanunu’na biraz daha yakından bakmak anlamlı olacaktır. Tanzimat dönemiyle birlikte medresenin yanında yeni eğitim kurumlarının açılması medrese ve mektep şeklindeki iki farklı kurumsal yapının mevcudiyetini ortaya koymuştur. Cumhuriyete geçiş sırasında söz konusu kurumların aynı çatı altında birleşmesi ve buluşması amacıyla "Tevhîd-i Tedrîsât" Kanunu çıkarılmıştır. Ancak araştırmalar mevcut kanunun amacı dışında yorumlandığını göstermektedir. Nitekim dönemin meclis kayıtları incelendiğinde vekillerin büyük çoğunluğunun bu duruma itiraz ettiği tespit edilmektedir. Daha doğrusu mevcut kanun medreseyle mektebi aynı çatı altında birleştirmeyi değil de medreseyi kaldırarak tek tip okulla yola devam etmeyi amaçlamış görünmektedir. Bu konudaki itirazların temelinde de medreselerin kapatılmasının ülkede ve özellikle ülkenin taşrasında din hizmetleri ve din eğitimi ihtiyacının karşılanamayacağı tespiti vardır. Açılan Darülfünûn İlahiyat Fakülte’sinin de öğrencisini o dönemde açılmış olan İmam Hatip mekteplerinden değil de liselerden alması bu okulların işlevsiz hale gelmesine sebebiyet verecektir. Hatta bu durumda medresenin yerine ihdas edilen Fakülte’nin öğrenci bulamayacağ 1 da dile getirilmiştir. Nitekim Erzurum Milletvekili Ziyaeddin Efendi ile Isparta milletvekili Hafız İbrahim Efendi hükümetin asıl amacının İlahiyat Fakültesỉne öğrenci göndermemek olduğunu iddia etmişlerdir. "Biz ilahiyat şubesine softaları kabul edemeyiz" diyen müderrislerin bulunduğu İlahiyat Fakültesi’nin de mevcut zihniyeti ve programının müftülük ve vaizlik gibi dinî görevleri yapacak İslâm âlimlerinin yetiştirilemeyeceğini iddia eden Mustafa Fevzi Efendi, İlmiye mekteplerinin açılmasını istemiştir. ${ }^{30}$ Ancak zaman içinde ihtiyacı karşılamasından endişe edilen Fakülte’nin kapanması, dinî alanda çok daha kötü süreçlerin yaşanmasına sebebiyet vermiştir.

Çok partili sürece geçiş sırasında geçmiş dönemlerden farklı olarak dinî konularda nisbî olarak yaşanan normalleşme, din eğitimi kurumlarının tekrar gündeme alınmasına

30 Tevhîd-i Tedrîsat Kanunu’nun yanlış anlaşıldığını düşünen Erzurum milletvekili Raif Efendi, bu uygulamanın halkı cehalete sürükleyip yozlaştıracağını düşünmektedir. Bu amaçla o, nüfusun ekseriyetini oluşturan büyük çoğunluğu cehaletin kucağına itmemek için başka irfan ocakları açmadan medreseleri kapatmanın kanunun ruhuna aykırı olduğunu öne sürmektedir. Dolayısıyla "zevk aldık" diyerek medreseleri kapatanlar Tevhîd-i Tedrîsat’ın ruhunu anlamamışlardır. Bu amaçla o şunları söylemektedir: Tevhîd-i Tedrîsat'tan maksat bütün dinî ve ilmî müesseselerde tedrisatın bir merkeze bir makama merbut olması manasınadır. Yoksa bunları yıkıp bir tanesini bırakmak değildir. Vahdetten maksat bu ise, hepsini yıkmalı idi. Hâlbuki tevhidin manası, merkezleri muhtelif olmasın, umumî bir merkeze merbut bulunsun demektir." (geniş bilgi için bk. Öztürk, s. 113-114). 
vesile olmuştur. İlahiyat Fakültesi’nin lağvedilişinden 16 yıl sonra 1949 'da bu defa ülkenin başkenti Ankara’da yeni bir Fakülte açılmıştır. Yukarıda da ifade edildiği üzere İsmayıl Hakkı Baltacıoğlu açılışs sırasında yaptığı konuşmada konuyu anlaşılır kılacak bazı açıklamalarda bulunmaktadır ki bunlardan birisi de Fakültenin konumuyla alakalıdır. Nitekim o, Dârülfünûn tecrübesini bir çeşit Sosyoloji Fakültesi olduğu tespitinde bulunduktan sonra, Ankara İlahiyat'ın ise İslâmî bilgilerin esas alındığı, sosyolojik bilgilerin ise yardımcı olacağı bir Fakülte olacağ $1^{31}$ temennisinde bulunmaktadır. Ancak temenni olarak ifade ettiğimiz bu tespitin, uzun zaman hayata geçirecek fırsatı yakalayamadığı aşağıda ayrıntısıyla açıklanacaktır. Baltacıŏglu sözlerine devamla "bizim istediğimiz İslâm İlahiyat Fakültesi, İslâm dinini, İslâm mezheplerini, ilmî surette tetkik edecek ilmî bir Fakülte. Tabir maruz görülsün, mahallî ihtiyaçları unutup da bilmem nasıl mücerret bir spekülasyon zihniyetiyle sosyoloji, metafizik ilmine batıp İslâm dini bilgilerini prensipleri dışında bırakırsa maksat hâsil olmaz..."32 demektedir.

İlahiyat Fakültesi açılmadan önce yapılan müzakereler sırasında Fakülte'nin isminin sadece İlahiyat değil de İslâm İlahiyatı olması üzerindeki tekliflere rağmen İslâm kelimesinin tercih edilmemesi, dönemin niyetini göstermesi açısından altı çizilmesi gereken hususlardandır. Nitekim Ahmed Hamdi Aksekili bu durumu şu şekilde dile getirmektedir:

"Üniversite'de açılacak olan Fakülte'den maksat, burada bilhassa İslâm ilimlerine ehemmiyet verilerek güya istediğimiz din adamlarının yetişmesini temin etmektir. Hâlbuki sonradan Fakülte'ye ait olmak üzere üniversite tarafından hazırlanmış olan kanunda İslâm kelimesi kaldırılarak yalnız İlahiyat Fakültesi diye teklif edilmiştir." ${ }^{33}$ Bu gelişme, Fakülte’nin istenilen anlamda din mütehassısı yetiştirip yetiştirmeyeceği noktasındaki soru işaretlerini kendisinde barındırmasına zemin hazırlamıştır.

Nitekim 4 Haziran 1949'da kabul edilen 5424 sayılı kadro kanunuyla kurulan İlahiyat Fakültesi 21 Kasım 1949'da öğretime başlamıştır. Ancak fakülte yanında İmam Hatip mekteplerinin açılması, bu zamana kadar kimsenin dikkatini çekmediği önemli meselelerin gün yüzüne çıkmasına sebebiyet vermiştir. Bunlardan birisi, kurumlar açılmakla birlikte buralarda istihdam edilecek tahsilini dinî ilimler sahasında yapmış salahiyetli öğretim üyesinin bulunamamasıdır. O yıllarda fakülte mevcut ihtiyacını karşılama amacıyla ister istemez tarih, edebiyat, klasik Şark filolojisi bölümlerinden öğretim üyesi almak zorunda kalmıştır. Ancak söz konusu hocalardan çoğu akademik kariyeri olmakla birlikte doğrudan İslâmî ilimlerle ilgisi bulunmayan kimselerden oluşmaktadır. Bunlardan yalnızca eski imparatorluk yadigârı ülkelerde yetişmiş olan Tayyip Okiç gibi Boşnak, Mağripli ve Hindli olanların İslâmî İlimlerde yetkin istisnaî isimler arasında yer aldığı dikkati çekmektedir. Bu durum İlahiyat Fakültesinin yerli öğretim kadrosuyla istenilen manada faaliyette bulunabilmesi için yirmi yıla yakın bir zamanın geçmesini gerektirmiştir. ${ }^{34}$ Nitekim Fakülte’nin ilk yıllarında öğrencilik yapanlarla yapılan mülakatta dinî ilimlerin tahsilinde sıkıntı çektikleri, hatta lise mezunu olan büyük çoğunluğun Kur'an-1 Kerîm okumayı öğrenmek için uzun bir zaman değişik imkânları devreye sokmak zorunda kaldıklarını belirtmektedirler.

31 Ayhan, Türkiye'de Din Eğitimi, s. 221.

32 Mustafa Öcal, Tanıkların Dilinden Cumhuriyet Dönemi Din Eğitimi ve Dini Hayat, İstanbul 2008, II, 365.

33 Aksekili, s.151.

34 Erol Güngör, İslâmin Bugünkü Meseleleri, İstanbul 1989, s. 209-210. 
Meselâ (Prof. Dr.) İsmail Cerrahoğlu’na Baltacıŏglu’nun Fakülte'nin fonksiyonuyla ilgili temennîleri sorulduğunda "Esefle söyleyeyim ki Baltacıŏlu’nun dedikleri ile fakültedeki ders programları asla mutabık olmamıştır. Bizler ilk günlerde aradığımız şeyleri bulamadık. Onlar da istedikleri şeyleri bizde bulamadı. Bunun yerine derslere "medrese hocaları gelseydi ne olurdu?" sorusuna karşı da o, "medrese hocaları gelmiş olsaydı söz konusu derslerde onlar Arapça kitaplar okutacaklardı, öğrencilerin fikir ufku daralabilirdi, ama buna mukabil Arapçaları kuvvetlenirdi. Medrese zihniyetinin hortlayacağını zannetmiyorum” şeklinde cevap vermiştir. M. Hulusi Özkul da İslâmî alanda öğrendiklerinin hemen hepsini dışarıdan arayıp buldukları medrese hocalarından öğrendiklerini söyleyerek onların gelmiş olmalarının medrese zihniyetini hortlatacağ

İlahiyat Fakülte'sinin ilk mezunlarıyla yapılan röportajlarda Kur’an-1 Kerîm, Arapça ve dinî derslerle ilgili Fakülte'den neredeyse hiç istifade edemediklerini ifade ettikleri görülmektedir. Hemen hepsi bu konudaki eksikliklerini telafi etmek amacıyla dışarıdan kendilerini takviye edecek imkânları devreye sokmaya çalıştıklarını dile getirmektedirler. Aslında öğrenciler başlangıçta bu konuyla ilgili teşebbüslerini fakülte içinden karşılamak istedikleri halde bu isteklerinin karşılık bulmadıklarını söylemektedirler. Nitekim öğrencilerden bazısı bu durumu "çok acayiptir ki bizim okuduğumuz yıllarda fakültede Kur'an dersimizin olmaması harf inkılabına uygun değildir (?!?) nedenine bağlanmaktaydı” şeklinde dile getirmektedirler. ${ }^{36}$ Diğer bazısı da "Kur'an-1 Kerîm okumak, öğrenmek çocuk işi biz burada akademik öğretim yaptırıyoruz" şeklinde cevap aldıklarını belirtmektedirler. ${ }^{37}$ İsmail Cerrahoğlu da, ilk yıllarda Kur’ân-1 Kerîm ve Arapça dersleri olmadı̆̆ından sabah erken saatlerde Fakülte'ye gelerek Arapça ve Kur'ân-1 Kerîm bilen diğer arkadaşıla birlikte sınıf arkadaşlarını ikiye ayırıp Kur’ân-1 Kerîm ve Arapça okuttuklarını gündeme getirmektedir. ${ }^{38}$ Bu durum Fakülte’nin ilk açıldığı yıllardaki mevcut şartların din hizmeti ve din mütehassısı yetiştirecek atmosferden uzak olduğunu çok açık bir şekilde gözler önüne sermektedir. Nitekim bu şartlarda mezun olan öğrenciler hizmete başladıklarında tabiî olarak İmam Hatip okullarındaki ders ihtiyacını karşılamaktan çok uzak kaldıkları tespitinde bulunmuşlardır. Öte yandan Fakülte'nin böyle bir yapıya sahip oluşunun altındaki saikin dönemin siyasî erkin taleplerinden kaynaklandığ 1 anlaşılmaktadır. Bundan başka Fakülte’nin öğretim kadrosunun laik düşünce yapısına sahip olmakla birlikte yine de bazı resmî makamlar tarafından yakın takibe alınması, onda dinî alanda uzmanlaşmaya müsait bir ortamın oluşmasını imkânsız kılmıştır. ${ }^{39}$

Bu durum Fakülte'nin açılışındaki iştiyak ve sevincin zaman içinde yerini ümitsizliğe ve hayal kırıklığına bıraktığını ortaya koymaktadır. Bu sonuca götüren sebeplerin başında fakültedeki müfredatın beklentileri karşılayamaması ve din eğitimine çok geç yaşlarda başlanması gibi hususlar gelmektedir. Nitekim lise mezunlarından oluşan Fakülte öğrencilerinin mezun olacakları sırada İslâmî ilimlerde uzman veya yüksek dinî tahsil görmüş olduklarını kabul etmek, mevcut şartlarda oldukça zor ve hatta imkânsızdır. İslâmî ilimlerle

35 Mehmet Hulusi Özkul, Tanıkların Dilinden Cumhuriyet Dönemi Din Eğitimi (haz. Mustafa Öcal), İstanbul 2008, I, 596.

36 Geniş bilgi için bk. Sevim Aykara, Tanıkların Dilinden, I, 292-294.

37 Özkul, I, 594.

38 İsmail Cerrahoğlu, Tanıkların Dilinden (haz. Mustafa Öcal), İstanbul 2008, III, 20-22.

39 Şaban Sitembölükbaşı, Türkiye’de İslâm’n Yeniden İnkişafı, Ankara 1995, s. 95. 
ilgili temel alt yapıyı almadan Fakülte’ye gelen öğrencilere okulun istenilen hedefi sağlayacak eğitim vermesi maalesef söz konusu olmamıştır. Öğrencilerin tüm konuları fakültede öğrenmek zorunda kalmaları, istenilen din mütehassısı olmaları önündeki en büyük engellerden birini oluşturmaktadır. Nitekim İslâmî ilimlerde tedris yapabilmenin önemli şartlarından biri, Arapça ve Osmanlıca kaynakların orijinalinden okunabilmesi ve müfredatın terkip ve tabirlerinin bilinmesidir. Eğer öğrenciler bu bilgilerin tamamını Fakülte'den alacaklarsa, bütün tahsil müddetince zamanlarını bunları öğrenmeye ayırmak gerekir ki bu durumda asıl maksat olan dinî ilimlerin araştırılmasına zaman kalmaz. Yine talebe bu kudrette yetişmeyecekse ona okutulup öğretilecekler basmakalıp ders notlarının ezberlenmesinden ileri bir çaba olmaz. ${ }^{40}$

Ali Fuat Başgil de İlahiyat Fakültesi’ndeki hoca kadrosunun yeterli olmaması ve meslek derslerinden ziyade sosyoloji ve felsefe ağırlıklı dersler görmeleri, öğrencileri yüksek ilahiyat felsefecisi ve sosyologu yaptığı halde asla din mütehassısı, din adamı ve âlimi yapmayacağı düşüncesindedir. Nitekim gerçek din mütehassısı halis bir müslüman, zahid ve müttakidir, sonra da inandığı ve samimiyetle kânî olduğu dinde yüksek ilim ve kemâl sahibidir. $\mathrm{Bu}$ vasıflardaki bir insanın yetişmesi için nasıl bir hava ve muhitin mevcut olması lazım geldiği bilinir. Şurası muhakkaktır ki dünyanın hiçbir yerinde laik üniversite çatısı altındaki İlahiyat Fakülte’sinden din adamı ve âlimi yetişmesi beklenemez. O, Batı'daki Üniversite atmosferinin bize de taşındığı düşüncesinden hareketle lâ-dînî bir camia içinde din adamı ve âliminin kesinlikle yetişmeyeceği kanaatindedir. Devlet mekteplerinde ortaokul ve lisenin lâ-dînî havası, hatta din aleyhtarı muhit içinde yetişip on dokuz veya on sekiz yaşına gelen bir gencin aldığı din aleyhtarı terbiye ve menfi zihniyetle idaresi ve hocaları çok kere dine muârız olan sivil bir İlahiyat Fakülte'sinde okuyup da din adamı olmasını beklemek safdillikten başka bir şey değildir demektedir. ${ }^{41}$

Ahmet Hamdi Aksekili de Fakülte’nin ihtiyaca cevap verecek vasıfları taşımadığını şu ifadelerle dile getirmektedir: "Bu Fakülte'ye girebilmek için sadece lise mezunu olmak kafî görüldü. Binaenaleyh bugünkü İlahiyat Fakültesi memlekete lüzumlu olan din adamlarını yetiştirecek durumda değildir. Ve bu şerâit altında bunun imkânı yoktur. Bununla beraber biz üniversite dâhilinde böyle bir Fakülte’nin bulunmasına muârız değiliz. Bizim istediğimiz belki memleketin her sahasındaki dinî ihtiyaçlarla mütenâsip yüksek İslâm âlimleri yetiştirebilecek hakikî bir din müessesesidir." ${ }^{42}$ Bütün bu gelişmeler, Fakülte’ye alınan öğrencilerin din eğitimi almış olarak gelmelerini gerekli kılmaktadır. Bu durum öğrencilerin İmam Hatip mektepleri türü bir kurumdan mezun olmasını gerekli kılmaktadır.

Dönemin öğrencileri ile Fakülte’nin durum ve konumunu inceleyen gözlemcilerin hemen hepsi Fakülte’nin başarılı olması açısından din eğitimi alanındaki eksiklerin giderilmesini gerekli görmektedirler. Aslında fakülte 1949 'da açıldığında tabiî olarak bu imkândan yoksundu, ancak 1951 yılında öğretime başlayan İmam Hatip okullarının 1957/1958'de mezun vermeye başlamasından sonra da aynı tutumun devam etmesi, kurumun açılış amacl çerçevesinde izah edilir bir durum değildir. Her ne kadar İmam Hatip liselerinin 1973’e

40 Ayhan, Türkiye’de Din Eğitimi, s. 226.

41 Başgil, s. 210-211.

42 Aksekili, s. 151-152. O dönemlerde yüksek din eğitimi vermek üzere açllacak olan bir kurumun nereye bağlı olması gerektiğiyle ilgili görüşmelerde Aksekili, okulun din hizmetleri yapacak öğrenci yetiştirmesinden hareketle Diyanet İşleri Başkanlığı’na bağlanması gerektiğini ileri sürmüştür. 
kadar üniversiteye gitme haklarının bulunmaması şeklinde bir engelden bahsedilse de söz konusu engelin aşılamaması, daha ilginç bir görünüm arzetmektedir. Fakültenin amacı gerçekten yüksek din eğitimi vermekse liseden bu temeli almış öğrencileri kabul etmemesi veya mevcut engelleri aşmaması, makul gerekçelerle açıklanabilecek gibi durmamaktadır. Belki mevcut durumu, "dönemin anlayışını gözler önüne seren ilginç bir tablo şeklinde izah etmek” en uygun açıklamadır.

Fakültenin kısaca işaret edilen durumu ve din uzmanı yetiştirmedeki yetersizliği, yeni arayışlara gidilmesini kaçınılmaz kılmıştır. 1951'de eğitim ve öğretim faaliyetlerine başlayan İmam Hatip okullarının mezun vermeye başlaması da bu taleplerin güçlenmesine zemin hazırlamıştır. İmam Hatip okullarının normal bir orta öğretim kurumu olmaları yolundaki çabaları, onların yükseköğrenim kurumlarından da istifade edebilme imkânını gündeme getirmiştir. Ancak onların ne orta öğrenim kurumu kabul edilmeleri ne de yükseköğrenim hakkından istifade edebilmeleri çok kolay olmamış, oldukça uzun bir mücadeleden sürecinden sonra bu haklara sahip olmuşlardır. Dolayısıyla bir yandan mevcut İlahiyat Fakülte'sinin din mütehassısı yetiştirebilecek zeminden uzak olması, diğer taraftan İmam Hatip okullarının mezun vermesi, yeni kurum arayışlarına yönelmeye sevk etmiştir. Söz konusu talepler İstanbul'da bu şartları yerine getirecek Yüksek İslâm Enstitüsü kurulmasını hızlandırmıştır. ${ }^{43}$ Nitekim Ali Fuat Başgil'in de İlahiyat Fakültesi’yle ilgili tespitleri, Yüksek İslâm Enstitüsü gibi yeni bir kurumun ivedilikle hayata geçirilmesi taleplerini gündeme getirmiştir. Ancak Fakülte’nin dışında açılan Yüksek İslâm Enstitüsü, bir yandan İmam Hatip Okulu mezunlarının bir üst kademe yüksek öğrenim yapmasına zemin hazırlarken diğer yandan da Diyanet teşkilatındaki müfti ve vaiz gibi kadrolara eleman yetişmesini sağlamıştır. Ancak bu gelişmeler, birbirinden farklı iki din eğitim kurumunun gün yüzüne çıkmasına sebebiyet vermiştir. Nitekim her ikisinin kuruluş amacı ve konumu incelendiğinde birbirine yakın hedeflerini olması niye iki farklı yapıda din eğitimi kurumları açılmıştır? sorusuna cevap verebilmeyi zorlaştırmaktadır. İlahiyat Fakülte'si İmam Hatip Okulu mezunlarını alarak ve ihtiyaca binaen yeni fakültelerin açılmasıyla bu mesele çözülebilirdi. Böyle bir yol takip etmek yerine birbirinden farklı konumda iki kurumun açılması izah edilir bir durum gibi görünmemektedir. Bu şekilde aynı amaca hizmet eden, ancak birbirinden farklı konum ve fonksiyona sahip söz konusu kurumlar zaman içinde İslâmî ilimlerin incelenmesinde İstanbul ve Ankara şeklindeki iki farklı bakış açısının gündeme gelmesine de sebebiyet verecek süreci başlatmıştır.

İlahiyat Fakültesi ile Yüksek İslâm Enstitüsü’nün kız öğrenci açısından durumuna bakıldığında şöyle bir tabloyla karşılaşılmaktadır: Ankara Üniversitesi İlahiyat Fakültesỉnin öğrencisi liseden geldiğinden açıldığ yıldan itibaren kız öğrenci almış ve ilk mezunlarını 1953 yılından itibaren vermeye başlamıştır. Meselâ 1953'teki 40 öğrenciden yalnızca 9 tanesi kız öğrencidir. Yüksek İslâm Enstitülerine baktığımızda onların öğrencisi İmam Hatip

43 1959'daki Millı̂ Eğitim Bakanlı̆̆ı Müdürler Komisyonu’nun, Tâlim ve Terbiye Kurulu’nun kararına dayanan 17 Kasım 1959 gün ve 575 sayılı kararı ile İstanbul Yüksek İslâm Enstitüsü açılmıştır. İmam Hatip okulları mezunlarını kabul eden dört yıl süreli enstitüyü Konya (1962), Kayseri (1965), İzmir (1966), Erzurum (1969), Bursa (1975), Samsun (1976) ve Yozgat (1980) Yüksek İslâm enstitüleri takip etmiş, Yozgat Yüksek İslâm Enstitüsü 1981'de bakanlıkça kapatılarak Atatürk Üniversitesi İslâmî İlimler Fakültesi'yle birleștirilmiștir. 20 Temmuz 1982 tarih ve 4 sayılı kanun hükmündeki kararnameyle bu Fakülte ile diğer Yüksek İslâm enstitüleri İlahiyat fakültelerine dönüștürülerek bulundukları illerin üniversitelerine bağlanmışlardır (Ayhan, “İlahiyat”, XXII/71). 
liselerinden geldiğinden ilk yıllarda kız öğrenciye rastlama imkânı bulunmamaktadır. Bu amaçla öncelikle İmam Hatip okullarındaki kız öğrenci varlığına bakmak isabetli olacaktır. İmam Hatip okullarına kız öğrenci alınmaya başlaması, 1960 sonrasındaki yıllara denk gelmektedir ve sayısı da bir elin parmağını geçmeyecek kadardır. Mezun verme açısından durumlarına bakıldığında ise -elimizdeki verilere göre- 1969/1970 yıllına gitmemiz gerekmektedir. 1963/1964'te Gaziantep İmam Hatip Okulu’na başlayan Fatma Zehra Kanlı'nın hem İmam Hatip Okulu’ndan ilk mezun olan kız öğrenci olduğu hem de aynı yıl Konya Yüksek İslâm Enstitüsü’ne kayıt yaptırdığı görülmektedir. Daha sonraki diğer bir tecrübe de Antalya İmam Hatip Okulu’nun üçüncü dönem mezunlarından Muazzez Uysal ve ikinci dönem mezunlarından Fatma Çetin'le İzmir Yüksek İslâm Enstitüsü’nde (1972-1973) yaşanmıştır.

Araştırmalarımız sonucunda elde ettiğimiz verilerden hareket edildiğinde 1960 ile 1970 yılları arasında Türkiye’nin değişik bölgelerindeki az sayıdaki İmam Hatip okullarına -sayısı çok olmasa da- kız öğrenci alınmasına başlandığı görülmektedir. Ancak bu yıllardaki sayının çok olmaması olayın bir anlamda münferit kişisel çabalarla geliştiğini ortaya koymaktadır. Kayda değer denilebilecek öğrenci sayısının ise 1967/1968'de Isparta ve 1968/1969'da Denizli'de müstakil kız sınıfları, 1969/1970'te de Çorum da ayrı bina tahsîsi şeklinde hayata geçirildiği görülmektedir. Hadisenin bu çerçeveden gelişme göstermesi, kız öğrencilerin Yüksek İslâm Enstitülerine gitmesinin 1970'li yılların ortalarıyla sonlarına denk geldiğini göstermektedir. İstanbul Yüksek İslâm Enstitüsü’ne baktığımızda 1975 yılından itibaren Enstitüye kız öğrenci alımına başlandığı ortaya çıkmaktadır. Nitekim bu durumun tabii bir neticesi olarak 1979-1980 öğretim yllında 3 tane kız öğrencinin mezun olduğu tespit edilmektedir. 1980-1981'de bu sayı 1, 1981-1982'de de 3 tane olup Yüksek İslâm döneminde toplam kız öğrenci sayısının 7 kişiyle sınırlı olduğu tespit edilmektedir. 1982-1983 öğretim y1lıyla birlikte enstitülerin Fakülte’ye dönmesini müteakip, Marmara Üniversitesi İlahiyat Fakültesi'nden o yılda 2 öğrencinin mezun olduğu dikkati çekmektedir. Ancak 1972 ile 1976 yılları arasında İmam Hatip liselerinde okuyacak öğrencilerin “erkek olması" şartının konması, henüz kurumlardaki kız öğrenci sayısının emekleme aşamasındayken yok olma sürecine girmesine sebebiyet verdiği anlaşılmaktadır. Bundan ötürü 1980'li yıllarda Enstitülerde kayda değer bir kız öğrenci sayısından bahsetmek mümkün değildir. Durumun bu şekilde gelişmesi, enstitü ve fakültelere İmam Hatip Okulunu bitirmiş öğrencinin bir süre daha gitmesini engellemiştir. Enstitülerin 1982/83 yılında Fakülte’ye dönmesinden hemen kısa bir zaman sonra 1985-1986 yılında bu defa da kız öğrenci sayısında kontenjan kısıtlamasına gidildiği görülmektedir. Bunun temel sebebi dönemin 1980 askeri darbesi altında yatmaktadır. Askeri darbenin baş aktörü Kenan Evren'in ilk icraatlarından biri de eğitim kurumlarında başörtüsü yasağını uygulamaya koymasıdır. Cumhurbaşkanı sıfatıyla diğer bir faaliyeti de din eğitimi kurumlarıyla ilgili düzenlemelerde bulunarak İlahiyat fakültelerinde yeni yeni okumaya başlayan kız öğrencilerin sayılarını kısıtlamasıdır. Bu hususu izah edebilecek en iyi açıklama, kız öğrencilerin görünür olması, başörtüsünün yaygınlaşmaya başlaması anlamına geleceğinden önce başörtü yasağıyla, daha sonra da kontenjan kısıtlamasıyla yaygınlaşmanın önüne geçilmeye çalışılmıştır. Aslında bu konunun uygulamaya başlandığı dönemler incelendiğinde zaten kız öğrenci sayısının oldukça az olduğu tespit edilmektedir. Dolayısıyla kontenjan engelini "toplumda veya kamu sektöründe İlahiyat Fakülte'si mezunu kızlara ihtiyaç hissedilmemektedir” şeklinde izah etmenin hiçbir makul 
gerekçesi yoktur. Meselâ ilk Yüksek İslâm Enstitüsü olan Marmara Üniversitesi İlahiyat Fakültesi’nin kız öğrenci sayısına bakıldığında şöyle bir tabloyla karşılaşırız: 1982/1983'te 2, 1983/1984'te 6, 1984/1985'te 12 tanedir. 1985/1986'da da kız öğrenci kontenjanında \%7’lik bir kısıtlamaya gidilmiştir. Yani kısıtlamanın başladığı dönemde Fakülte’den başlangıcından itibaren yalnızca 20 kız öğrencinin mezun olması, bu durumun başka şekilde izah edilmesini gerekli kılmaktadır. Dolayısıyla kısıtlamayı geçmişte 1970 muhtırası sonrasındaki "erkek olmak" şartının "yeni bir ihtilal sonrasındaki farklı bir versiyonu” şeklinde yorumlamak gerekmektedir. Nitekim askeri vesâyet döneminde (30 Aralık 1982) YÖK tarafından yayınlanan kılık-kıyafet genelgesinde üniversitelerdeki öğrenci ve görevlilerin başlarının açık olmaları ve kurum içinde başlarını örtmemeleri emredilmektedir. Daha sonra $10 \mathrm{Ma}-$ y1s 1984’te de (Özal Hükümetinin etkisiyle) YÖK öğrencilerin modern bir şekilde türban kullanabileceklerini öngören başka bir genelge yayınlamıştır. Bu serbestiyet ise, o dönemin vesayetçi düşüncesi açısından ülkede başörtülülerin artacağı bir süreci başlatacaktır. Bunun önüne geçmek için 1985/1986'da kız öğrenci kontenjanlarının kısıtlanmasıyla başı örtülü öğrenci sayısının azaltılmasına gidilmiştir. Böylece bir yerden engel kalkar gibi görünürken öbür taraftan farklı bir kısıtlamayla müdahale devam etmiştir. 1985/1986'daki \%7'lik ${ }^{44}$ kısıtlama 1986-1987'de de aynı şekilde devam etmiş, 1987-1988'de bu kısıtlama \%4'e indirilmek suretiyle $^{45}$ ağırlaştırılarak 3 yıl daha devam etmiş ve nihayet söz konusu durum 1990-1991 eğitim-öğretim yılında sona ermiştir.

Bütün bu gelişmeler, İmam Hatip liseleri ve İlahiyat fakültelerinde okuyan kız öğrencilerin durumu erkek öğrencilerle mukayese edildiğinde başta kontenjan kısıtlaması ve başörtüsü yasağı olmak üzere daha sıkıntılı süreçlerden geçerek bugünlere geldiğini göstermektedir. Diğer bir ifadeyle Türkiye'de din eğitimi kurumlarının kurulup gelişmesi sancılı süreçlerden geçerken, aynı tecrübenin kızlar açısından durumu ise, biraz daha çileli ve sıkıntılı olmuştur. Hatta onların yaşadığı sıkıntılar, başta başörtüsü tartışması olmak üzere hem daha geniş çerçevede, hem de daha geniş kesimler tarafından gündeme taşınmıştır. $\mathrm{Bu}$ konu din ve modernleşmenin bir parçası olarak kadın projesi üzerinden gerçekleşmiş, kadının kamusal hayata katılıp katılmaması ya da eğitim kurumlarına gidip gitmemesi, giderse başını örtüp örtmemesi gibi konular çerçevesinde ele alınmıştır. Demokles'in kılıcı misali bu mesele, dindar ve laik kesimlerin her ikisi tarafından kız öğrencilerin din eğitimi kurumlarına devam edip etmemelerinin meşruiyetlerinin sorgulanmasını da beraberinde getirmiştir.

Kadınların kamusal alanda İslâmî kimlikleriyle görünmek istemelerinden kaynaklanan söz konusu durum, oldukça sert ve baskıcı politikalarla hayata geçtiğinden, olay çı̆̆ırından çıkarak izah edilmesi zor bir hâl almıştır. Bu politika, meseleyle ilgili bir birbirinden taban tabana zıt ve farklı yorumların yapılmasına, dinî boyutuna yeni bakış açıları getirilmesine veya bu problemi aşmak amacıyla oldukça farklı çözüm yollarına gidilmesine sebebiyet vermiştir. Bütün bu yaşananlar da konunun mağduru kız öğrencileri veya kamuda çalışan kadınları içinden çıkılması zor bir girdaba sürüklemiştir. Bu sırada yaşanılan en sıkıntılı çözüm ise, meseleyi kadınların omzuna yıkarak bu konunun onların kendi şahsî

44 "Bu programın \%7’si kız öğrencilere ayrılmıştır" ifadesi Kılavuzda yer almaktadır. bk. 7. "mad." 1985 Öğrenci Seçme ve Yerleștirme Sinavı Kılavuzu.

45 "Kontenjanın \%4’ü kız öğrencilere ayrılmıștır” ifadesi Kılavuzda yer almaktadır bk. 22. "mad." 1987 Öğrenci Seçme ve Yerleștirme Sinavi. 
meseleleriymiş gibi lanse edilmesi ve konunun onlar tarafından halledilmesinin beklenmesidir. Yani mesele dinin bir uygulaması ve emrinden ziyade kız öğrencilerin her birinin meselesiymiş gibi algılanması, öğrencilerin kendi kaderlerine terk edilmesini beraberinde getirmiştir. Nitekim mağduriyet yaşayanların hemen her biri kadar, birbirinden farklı hikâyenin mevcudiyeti, yaşanılanların zorluğunu gösterecek boyuttadır. Bu açıdan oldukça teferruatlı ve geniş bir tartışma alanına sahip olan tesettür konusuna, -burada tüm boyutlarla incelenmese de- din eğitimi kurumları açısından kısaca değinilmesi uygun olacaktır.

\section{Tesettür Meselesi}

Modernizmin kadını toplumsal hayatta görünür kılması, tesettür meselesini de beraberinde getirmiştir. Konuların ilk defa ele alınıp tartışıldığı zamanlarda, dönemin İslâmcı yazarları kadının İslâmî yaşamıyla toplumsal alanlarda bulunmasını tasvip ederek onaylamışlardır. Ancak Cumhuriyet döneminde kamusal alanın gerekliliği olarak kadınların kılık kıyafetlerinde düzenlemeye gidilmiş ve bu tür mekânlarda kadınların başlarını açmaları gerekli görülmüştür. Başörtüsünün kamusal alanda ortaya çıkışı Atatürk ilke ve inkılâplarına karşı gelme şeklinde algılanmış ve bunun dayatmaya dönüşmesi, gerçekçi olmasa da Cumhuriyet tarihi boyunca hiç gündemden inmeyen konular arasında yer almıştır. Dolayısıyla kısaca bu mesele üzerinde durmak, konunun anlaşılması açısından uygun olacaktır.

Modernleşmenin kadın üzerinden gerçekleşmesi gerek İslâmcı gerek Batıcılar tarafından kadının toplumdaki konumuyla ilgili teoriler oluşturulmasına sebebiyet vermiştir. Bundan ötürü sık sık kadının başını örtüp örtmemesi, din veya laik Cumhuriyet açısından ne ifade ettiği medyanın ve akademik camianın hayatî konularından biri arasında yer almıştır. Bir yandan teorik tartışması sahnede yerini alırken diğer yandan da hemen her ihtilal döneminin ardından İmam Hatip okullarında ve fakültelerde yasağın uygulanması öncelikli konulardan biri olmuştur. Özellikle İmam Hatip okullarına kız öğrencilerin başlamasıyla bu husus, gündemdeki yerini korumuş ve öğrencilerin okullarda başlarını örtmeleri Cumhuriyet'e ve Atatürk ilke ve inkılâplarına karşı gelme olarak anlaşılmıştır. İncelemeye aldığımız okulların hemen hepsinde öğrencilerin önüne bu problemin çıtığ 1 ve onların bu engeli aşmak için değişik metotlarla mücadele etmek durumunda kaldıkları tespit edilmektedir. Din eğitimi yapmak veya din hizmeti vermek üzere açılmış olan kurumlarda dinin emri olan bir meselenin problem olarak algılanmasını okulların açılma amacıyla bağdaştırmak ve izah etmek oldukça güçtür. Eğitim kurumları dışında da konu, kamusal alan açısından dinî simgelerin ifade edilmesi üzerinden problem görülerek yasaklanmıştır. Dolayısıyla kamusal alanda görev yapmak isteyen kadınlar bu konularda ya mesleği ya da başörtüsünü tercih etmenin eşiğine gelmişlerdir. Bu konudaki ilk isimlerin içinde Celal Ökten'in kızı Hümeyra Ökten (1949) gelmektedir. ${ }^{46} 15$ sene sonra 1964'de İstanbul

46 İmam Hatip mekteplerinin kurucu müdürü Celal Ökten’in kızıdır. Tıp Fakülte’si mezunudur. Dinin toplumsal hayatta görünür olması ve kadının dindar kimliğiyle var olabilmesinin zor olduğu dönemlere şahit olmuş, dahası o dönemlerde orta öğretim ve fakültede eğitim görmüştür. Çok sevdiği üniversiteden ihtisasını yaptıktan sonra başörtüye sıcak bakılmadığından dolayı ayrılmak zorunda kalmıştır. O durumu şu şekilde dile getirmektedir: asistanken hacca gider ve dönüşte klinik şefini ziyarete gider, hacdan geldiği için başörtüsünü çıkarmaz, hocasının onu görünce "ne öyle hacı hanımlar gibi" demesi üzerine üniversitede eșarplı hayat olmayacağını anladım "diploma almak zarurî ihtisası tamamlamak lazım, sonra her yerde çalışabilirim" diye kendi kendime teselli verdim. O zaman daha Müfide Hanım’ın asistanıydım Asistanlık müddetim bitti, ihtisas imtihanına girdim, onu da başarıyla verince 
Üniversitesi Tip Fakültesi’nden birincilikle mezun olan Gülseren Ataseven aynı problemle karşılamış, mezuniyet töreninde konuşmasına izin verilmemiş, onun yerine başını örtmeyen okul ikincisine konuşma yaptırılmıştır.

Başörtü konusunda bu dönemlerde genç kızları teşvik eden ve onlara rehberlik ettiği düşünülen isimlerden biri de Şule Yüksel Şenler’dir. O, abisinin tavsiyeleri üzerine başını örtmüş (1965) ve Yeni İstiklal gazetesiyle başladığı gazete yazarlığına uzun süre devam etmiş bir isimdir. Bu sıralarda Cumhurbaşkanı Cevdet Sunay'ın "sokaklardaki kapalı kadınların öncüleri cezalarını göreceklerdir” şeklindeki beyanı üzerine Şenler, "Cumhurbaşkanı Allah'tan ve milletten özür dilemelidir" tarzında bir yazı kaleme alır. Bunun üzerine o, dokuz aylık hapis cezasına çarptırılır. Daha sonra Cumhurbaşkanının affetmesine rağmen Şenler, affı kabul etmeyip hapiste kalmaya devam eder. Bundan başka o, ülkenin değişik bölgelerinde verdiği konferanslarla kızların başlarını örtmeleri ve İslâmî bir kimlik kazanmaları hususunda mücadele eder. Başörtüsü modeli toplumda yankı uyandırarak genç kızların başlarını örtmelerini teşvik ettiğinden ve bu konuda çı̆̆ır açtı̆̆ından model haline gelerek "Şulebaş" veya "sıkma baş" şeklinde anılmaya başlar. Bundan başka onun Huzur Sokağı adlı romanı da çok etkili olmuş ve hemen her gencin kütüphanesinde yer almıştır. ${ }^{47}$

Tarihsel tecrübeden anlaşılacağı üzere İmam Hatip okullarının normal bir orta öğrenim kurumu kimliği kazanmaları ve diğer kurumlarla benzer pozisyona sahip olmaları çok uzun bir zaman diliminden sonra olmuştur. Buralara kız öğrencilerin gelmesiyle de başörtüsü meselesi gündemden inmeyen konular arasında yer almıştır. Hatta Antalya gibi sahil kentlerinde kız öğrencilerin başlarını örtmeleri okul içinde ve dışında tepkilere neden olmuştur. Nitekim bu konu yalnız algıyla kalınmamış, rahatsızlık fiiliyata dökülerek kızların başlarındaki örtüye sözlü veya fiili müdahale etme yoluna da gidilmiştir. Meselâ Hatice Erdem kendi ifadesine göre başörtüsünden ötürü okulda matematik dersi öğretmeni tarafından cezalandırılarak sınıfta bırakılmış, sokakta yürürken Antalya İl Millı̂ Eğitim Müdürü tahammül edemeyerek örtüsünü başından çekmiştir. Yine okulun yanındaki Kız Sanat Okulu öğretmenleri de öğrenciler okulun önünden geçerken sözlü saldırılar da bulunmayı kendileri açısından gayet tabiî bir hak olarak görmüşlerdir. Diğer bir olay da Isparta İmam Hatip Okulu’nun bahçesinde gerçekleşir. İstiklal Marşı sırasında bir öğrenci başını açmayınca o sırada hazır bulunan öğretmenlerden biri olaya müdahale ederek öğrencinin başörtüsünü yırtar. Yine kızlar başlarını Kur'an-1 Kerîm dersinde örttükleri gibi diğer derslerde de örtmek isteyince, mesele büyüyerek kızların disipline gitmelerine ve hatta cezalandırılarak Denizli İmam Hatip Okulu’na tasdiknameyle uzaklaştırılmalarına sebebiyet verir. Görüşmelerimiz sırasında kızlar, başörtüsü yasağı hususunda okullarına gelen baskılardan birinin askerî makamlar tarafından olduğunu ifade etmektedirler. 71 muhtırasını düzenleyen askerî ekip içinde bulunan ve o sırada Isparta'da Tüm General olan Kenan Evren, kız öğrencileri dışarıda başı örtülü olarak görünce bu durumdan rahatsızlık duyarak okul yönetimini sık sık uyarmıştır. Yine o, 1980 darbesinin önde gelen isimleri arasındadır ve bu dönemdeki başörtüsü yasaklarında aktif rol oynamaktadır. Bundan başka o, konunun

"artık klinikten ayrılmak istiyorum dedim" Müfide Hanım "ne bu acele" dedi. "Babam emekli aileye katkım olsun istiyorum" deyip üniversiteden uzaklaştım. Sonra 1960 ihtilali oldu, 147 öğretim üyesine üniversiteden el çektirildi sanırım kalsaydım önce beni çekerlerdi rengim belliydi onun için üzülmedim, kariyer yapamazdım (Meriç, s. 111-112).

47 http://www.belgehaber.com/haber.php?haber_id=3753 (24.12.2015). 
türban şeklinde isimlendirilmesinin mimarları arasında yer almaktadır. ${ }^{48}$ Onun konuyla alakalı olarak tarihe geçen ifadelerinden birisi “Türkiye'de irtica tehlikesi var” şeklindedir. Diğeri de üniversitelere kız öğrenciler başlarını örterek gitmeleri durumunda, "Türbanlılar tamam, ama ya çarşaflılar ve mayolular da gelirse ne yaparız? " tarzındaki söylemidir. ${ }^{49}$

Bu konunun Yüksek din eğitimi kurumlarındaki durumu incelendiğinde Yüksek İslâm Enstitülerinin parmakla sayılır öğrenci aldığı dönemlerde henüz gündem teşkil etmediği görülmektedir. Ankara İlahiyat Fakültesi’ne bakıldığında onlar başlangıçtan beri bu konuda çok net bir tavır sergileyerek öğrencilerin başlarını örtmelerini mevzu bahis etmezler. Bu konunun ilk defa gündeme gelmesi, Hatice Babacan’ın Fakülte’ye başörtülü olarak girmek istemesiyle başlar. Böylece Üniversitedeki ilk tesettür meselesi, 1967'de Ankara Üniversitesi İlahiyat Fakültesi’nde İnkılâp tarihi dersinde gerçekleşir. Bunun üzerine başlayan tartışmalar, fakültede öğrenci olaylarının çıkmasını ve meselenin büyüyerek kontrol edilmesi imkânsız boyutlara ulaşmasını tetikler. Hatice Babacan’’n başörtüsüyle Fakülte’ye girmesi, o dönemki Fakülte idaresi tarafından hakaret kabul edilmiş ve onun (Şubat 1968'de) Fakülte'den atılmasına sebebiyet vermiştir. Ancak Hatice Babacan'ın cezalandırılması üzerine protestolar artmış; Fakülte içinden ve dışından boykota destek verilmiş ve iş içinden çıkılamaz hale gelince Fakülte tatil edilmiş, dekan ve bakan istifa etmek durumunda kalmıştır. Daha ilginç olan ise başlangıçta yalnız Hatice Babacan’ın başı örtülüyken bu olaydan sonra otuzdan fazla kız öğrenci başını örtmeye başlamıştır. ${ }^{50}$ Dönemin canlı tanıklarından Beyza Bilgin olayı bir gazete röportajında şu şekilde dile getirmektedir: "Başörtüsü tartışması, baş örtmek için mi, olay yaratmak amacıyla mı patlak verdi; bunu çözememişimdir. İlk olay, 1967'de bizde çıktı. Öğrencilerden biri, siyah, küçük bir başörtüsüyle, arka sıralara oturuyordu. Bunu ilk fark eden İnkılâp Tarihi hocası oluyor. "Niye başını örtüyorsun? Çıkart” diyor. Kız direniyor. Hoca kızı sınıftan atıyor. Ertesi gün hoca derse geliyor. Kız yok. Ama 5 kız; başlarını örtmüş, en önde oturuyor. Hoca tabii köpürmüş. Bahriye Üçok da hocanın doçentiydi; "İslâm Tarihi” doçenti. O da onları görüyor. Çok tepki gösteriyorlar. Bunun üzerine erkek öğrenciler de kızı müdafaa ediyor ve Bahriye Üçok içlerinden birini tokatlıyor. İki öğrenciyi disipline veriyorlar, bunlar okuldan atılıyor, olay gazetelere geçiyor.

48 Başörtüsüne üniversitelerdeki durumunun gündeme gelmesi 1980 'li yıllardan itibaren olmuştur. Ancak oldukça çalkantılı olaylar zinciri sırasında başörtüsü, bu sıralarda türban şeklinde isimlendirilmeye başlanmıştır. Kenan Evren'in Mehmet Keçeciler' in eşinin örtüsünü işaret ederek gündeme getirdiği ve Fransız modelinden esinlenerek türban adını verdiği örtünme, boynu açıkta bırakan ve kulakların arkasından dolanarak bağlanılan bir modeldir. İsimlendirme ve arayıșların temelinde başlangıçta ișaret ettiğimiz Türkiye’nin modernleștirilmesi ve bunun kadın üzerinden gerçekleştirilmesi meselesi, burada çok bariz bir şekilde görülmektedir. Nitekim 1980 darbesi sonrası YÖK başkanlığı yapan İhsan Doğramacı, "Evren bana bir gün, 'Kabine üyelerinin birisinin hanımı (Mehmet Keçeciler'in eşi) ne güzel, gayet çağdaş şapka gibi bir şey giyiyor, ne kadar medenice, bari başını örtmek isteyen başını bu şekilde örtse ne iyi olur' dedi. Lügat kitaplarına baktık. Fransa'da 'türban' diyorlar. Bone gibi bir şey. Başını kapatmak isteyenler için bu önerildi." Şeklindeki ifadesi bunun göstergeleri arasında yer almaktadır (bk. http:// bianet.org/bianet/siyaset/107522-1968-de-basortusu-ilk-fakulte-isgali-80-lerde-turban-ve-kenan-evren $\quad$ (15.12. 2016).

49 Başörtüsünün ilk defa veto edilmesi 1987 yılına denk gelmektedir. YÖK Kanunu’nda değişiklik yaparak başörtüsünün yeniden serbest bırakılmasını temin etmek amacıyla Turgut Özal (ANAP) hükümeti 1987 de "Yükseköğretim kurumlarında, dershane, laboratuar, klinik, poliklinik ve koridorlarında çağdaş kıyafet ve görünümde bulunmak zorunludur. Dini inanç sebebiyle boyun ve saçların örtü veya türbanla kapatılması serbesttir” șeklinde bir yasa çıkarmıștır. Ancak Cumhurbaşkanı Kenan Evren “Türbanlılar tamam ama çarşaflı ve mayolular da gelirse ne olacak" diyerek söz konusu yasayı veto etmiştir http://www.cumhuriyet.com.tr/haber/ diger/184516/Turban_tartismalari_60_larda_baslamisti.html\#(15.12. 2016).

50 http://www.risalehaber.com/zubeyir-abi-babacan-boykotunu-destekledi-122214h.htm (24.12.2015). 
Resimler, beyanatlar ve tüm partilerden öğrencilere destek geliyor. Bahçeye çadırlar kuruluyor. Açlık grevi başlıyor. Dışarıdan otobüslerle yemekler geliyor. Civar vilayetlerden destekçi, çelenk, çiçek derken olay büyüyor; her seferinde öğrencilerden başını örtenler artar."51

Yüksek İslâm enstitülerinin İlahiyat Fakülte’sine dönüşünden sonra başörtüsü meselesi sık sık İlahiyat fakültelerinin gündemindeki konular arasında yer almıştır. Özellikle YÖK ve siyasî erkin müdahalesi neticesinde İlahiyat fakülteleri üniversitelerde uygulanan başörtüsü yasaklarından nasiplerini almışlardır. Bu konudaki ilk yasaklama 1980 darbesi sonrasında hem İlahiyat fakültelerinde hem de İmam Hatip liselerinde belli bir dönem uygulanmıştır. Diğer ses getiren büyük yasaklama da 28 Şubat post modern darbesi sonrasında olmuştur.

\section{Değerlendirme ve Sonuç}

İlahiyat fakültelerinin Türkiyede köklü ve hedefleri belli bir kurum olmak yönünde çok çileli bir geçmişlerinin bulunduğu bir gerçektir. Durumun bu şekilde cereyan etmesi, hem onların hâlâ tartışmalı bir zemine sahip olduklarını, hem de hemen her siyasî dönemde müdahaleye açık bir yapılarının bulunduğunu göstermektedir. Kurumların halkın ihtiyaçlarına cevap verip verememe veya bulundukları üniversiteye entegre olup olamama açısından konumlarına bakıldığında her iki tarafla da istenilen şekilde diyaloga geçtiklerini söylemek oldukça zordur. Bu durumun tarihten gelen sebepleri yanında siyasî erk ve Cumhuriyet ideolojisinden kaynaklanan çok ciddî etkenleri de bulunmaktadır. Daha da önemlisi kuruluş aşamasında medreseden bağlarının koparılarak inşa edilmeleri, onların çok uzun bir süre normalleşme zeminine ulaşmak için bocalamalarına vesile olmuştur. ${ }^{52}$ Nitekim Ankara Üniversitesi İlahiyat Fakültesi mezunlarından bir kadın konuyu "Öğretmen yetiştiren kurumlar öğretmen adayı öğrencilerine öğretecekleri konuları hem teorik hem tatbikî olarak, yani stajlarla uygulamalarla öğretir ve eğitirdi. Biz İlahiyatçılar ise ne için ve neye hizmet için hazırlandık bilemiyorum. Bilgi kısıtlı ve noksan, tatbikat hiç yok, kendimizi öğretmen olarak birden öğrencilerin karşısında bulduk desem haksızlık mı olur acaba?"53 şeklinde gündeme getirmektedir. Bu girdaptan kurtulmak için bir yandan idealist öğrenciler azamî gayret sarfederken diğer taraftan tüm hayatını ilmî çalışmalara adamış parmakla sayılabilecek hocalar da gayret ve önderlikleriyle bu zorlu sürecin

51 Onun başörtüsü konusundaki yorumu o dönemki Fakülte’nin ve Laikliğin Türkiye’deki uygulamasıyla paralellik arzeder mahiyettedir. Nitekim başka bir röportajında o düşüncelerini şu şekilde açılar: "Oysa benim başörtüsü ile uzaktan yakından ilgim yoktu, başörtüsüne sempatim de olmamıştır. Başörtüsünün kadının başarısını geri çektiğini düşünmüşümdür. Öğretmenler ve Diyanet öğrencilere başörtüsünü Allah’’n emri olduğunu telkin ettiler” (Öcal, Bozok İmam Hatip, s. 382). Bundan başka 1980 darbesi sonrasında Milli Güvenlik Kurulu’nda bu meseleler tartışılırken o, okullarda din dersi konusunu tasvip edip desteklediği halde başörtüsü konusunda aynı tavrı takınmamıştır. Bu konuda İslâmiyet’te kadınların başlarını örtmelerinin farz olmadığını, bunun tavsiye niteliği taşıdığını, kendisi de evinde namaz kılarken (belki Kur’an okurken) başını örtme gereği hissetmediğini söylemiştir (bk. Tayyar Altıkulaç, Zorlukları Aşarken, İstanbul 2012, II, 644).

52 Fakültelerin mevcut durumu hakkındaki bu tespit, bugün ilk kuruluşlarında yapılan yanlışların telafisi anlamında tekrar müdahaleye açık oldukları manasına gelmemektedir. Tevhîd-i Tedrîsat Kanunu’nun medreselerin kapatılması şeklindeki yorumlanması, ülkenin dinî konularda gelenekle bağlarını kopararak fetret dönemi yaşamasına sebep olmuştur. Ancak bunun farkında olan kurumlar zaman içinde müdahalelere rağmen misyonlarını yerine getirmek amacıyla konumlarına uygun faaliyet ve yöntemler çerçevesinde kendilerine yeni bir gelenek oluşturarak bugüne gelmişlerdir. Dolayısıyla kurumların kendileriyle ilgili değiştirmeleri veya geliştirmeleri gereken hususlar varsa, dış müdahalelerle değil de bunları kendi inisiyatifleriyle gerçekleştirmeleri daha yapıcı ve kalıcı olacaktır.

53 Geniş bilgi için bk. Sevim Aykara, Tanıkların Dilinden Cumhuriyet Dönemi Din Eğitimi, I, 292-294. 
aşılmasını gögüslemişlerdir. Nitekim Hamdullah Suphi Tanrı̈̈ver'in bu konudaki beyanına kulak vermek, meselenin zorluğunu anlamak açısından önemlidir:

"Biz acaba tabiplik ve ordumuz için yaptığımız ıslahatı din teşkilatımız için de yapsaydık meyvelerini almaz mıydık? Mutlaka alırdık. Avrupa’nın eski üniversitelerini ele alalım; Sorbon'dan başlayarak -ki sekiz asırlık bir tarihe maliktir- Cambridge, Oxford, Almanya'da Heidelberg üniversiteleri evvelce birer medreseydi. Bu medreseler sslahatla bugünkü üniversiteler halini almıştır. Bizim tarihimizde de medreselerin sslahı yoluna gidilseydi, dokuz asırlık üniversitemiz vardır diye övünebilirdik. Ta Alparslan'dan başlayarak üniversitelerimiz gelişme göstererek son zamana kadar ilmî hareketleri takip edebilseydi, bugün bu mümkün olacaktı. Hâlbuki biz Tevhîd-i Tedrîsat Kanunu'yla hem medreseleri hem de İmam Hatip mekteplerini kapattık." ${ }^{54}$

Köksüz bir şekilde doğan kurumlar kendi içinde din eğitimi verme çabalarını sürdürürken kız öğrencilerin buralara katılmaları çok daha geç dönemlere tekabül etmektedir. $\mathrm{Bu}$ durum hem kurumların netliğe kavuşmamış fonksiyonundan, hem de kurum içi ve dışından meseleye bakışın her zaman çok sağlıklı şartlarda gelişmemiş olmasından kaynaklanmış olmalıdır. Şimdiki verilerimizden hareketle Yüksek İslâm Enstitüsüne ilk kız öğrenci girişi Gaziantep İmam Hatip Okulu'ndan mezun olan Fatma Zehra Kanlı’nın 1970’te Konya Yüksek İslâm Enstitüsü’ne kayıt yaptırmasıyla gerçekleşmiştir. 1972'de İmam Hatip okullarına gidecek öğrenciler için "erkek olmak" şartının konması o dönemde Yüksek İslâm Enstitülerine kız öğrenci almaya engel olmuş görünmektedir. Bu şartlar öğrencilerin ancak 1976'dan itibaren daha rahat bir şekilde Enstitülere gidebilme imkânı elde ettiklerini ortaya koymaktadır. Dolayısıyla enstitülerin Fakülte’ye dönüşmesine kadar nâdiren görünür oldukları söylense de kız öğrencilerin asıl varlığından bahsedeceğimiz yıllar 1980'den sonrasına tekabül etmektedir. Ancak bu sırada yeni bir darbenin gelmesi olayın ve eğitimin normal zeminde gelişmesini engellediğinden kız öğrencilerin görünür olması 1980'li yılların ortasına doğru hayata geçer. Diğer bir ifadeyle kayda değer mezun verme yılları 1980’lerin ortasıyla 1990’lı yılların başlarına rastlamaktadır. Bu da, bugünkü mevcut akademisyenlerin bir kısmının bu yıllardaki mezunlardan çıktığını ortaya koymaktadır.

Ankara Üniversitesi İlahiyat Fakültesi ile Yüksek İslâm enstitülerinin farklı tarihsel zemin ve ortamda doğmaları bu iki kurumun ayrı ayrı değerlendirilmesini kaçınılmaz kılmaktadır. Hatta ilk yedi Yüksek İslâm Enstitüsü ve daha sonra açılanlar ile son yıllarda açılanları da birbirinden ayırmak suretiyle incelemek daha sağlıklı olacaktır. Ankara Üniversitesi İlahiyat Fakültesi tecrübe itibariyle farklı bir konuma sahip olduğundan müstakil olarak değerlendirilmesi gereklidir. Onun ilk zamanlarda akademik kadrosunun ve öğrencilerin temel dinî bilgiler açısından yeterli olmaması gibi sebepler öğrencilerin dinî alanda uzmanlaşmış olarak mezun olmaları konusunda büyük bir engel teşkil etmiştir. Buna rağmen (Prof. Dr.) İsmail Cerrahoğlu gibi isimler mevcut durumlarını değişik açılardan takviye etmek ve kendilerini istenilen hedeflere ulaştırmak suretiyle yetiştirenler arasında yer almışlardır. Ancak bu durumu genelleştirmek mümkün olmayıp onların kendilerini fakülte dışı imkânlarla yetiştirmiş istisnâî kimseler olarak değerlendirmek daha doğru olacaktır. $\mathrm{Bu}$ yetersizliğin diğer önemli bir sebebi de akademik kadroların başlangıçta laik değerleri paylaşan kesimlerden oluşmasıdır. Ancak ilginç olan bu durum yine de Fakülte’nin siyasî 
baskılarından müstağnî kalmasını sağlayamamıştır. Bu şartlar onların kurum olarak kendi misyonlarını normal süreçte yürütebilmeleri önünde büyük bir engel oluşturmuş görünmektedir. Bu çerçeve Fakülte'nin bir yandan mezun veren ve akademik kariyer yapan bir kurum olmakla birlikte diğer yandan beklentileri karşlayacak dinî alanda yeterli olabilmesi için 1970'li yıllara kadar beklemesini gerektirmiştir. Söz konusu yıllar da kendi kadrosunu yetiştirdiği ve öğrenci olarak da dinî alt yapısı bulunan öğrencilere ulaştığı döneme denk gelmektedir. Bayan akademisyenler açısından durumuna bakıldığında bunlardan bazılarının dönemindeki diğer fakültelerden, diğerlerinin de kendi Fakülte’sinden mezun olan öğrencilerden oluştuğu dikkati çekmektedir. Özellikle Fakülte’nin açılışının II. Dünya savaşı yıllarına denk gelmesi başta Almanya olmak üzere Batı'dan ve Doğu'dan Türkiye’ye gelen akademisyenleri misafir hoca olarak bünyesine alması dönemine tesadüf etmektedir. Bu durum, akademik tecrübeyi kendilerine aktarabilme firsatı yakalaması açısından büyük bir avantaja dönüşmüştür. Nitekim Prof. Dr. Annemaria Schimmel bu çerçevedeki isimlerin başında gelmektedir. İlk bayan akademisyen Bahriye Üçok ise İlahiyat Fakülte’si mezunu olmamakla birlikte İslâm Tarihi alanında Fakülte'ye intisap eden isimler arasında yer almaktadır. Diğer isimler de Felsefe profesörü Kamuran Birand ile Türk İslâm Edebiyatı profesörü Meliha Anbarcıoğlu'dur. Ankara Üniversitesi İlahiyat Fakültesi’nden mezun olan akademisyenler ise, Din Psikolojisi’nde Prof. Neda Armaner ile Din Eğitimi’nde Prof. Dr. Beyza Bilgin'dir. Schimmel dışındaki adı geçen isimlerin bölüm olarak Temel İslâm Bilimleri haricindeki branşlara müntesip olmaları, hatta bunun yakın zamana kadar böyle devam etmesi, dikkat edici bir sonuç olarak görünmektedir. Bahriye Üçok, Meliha Anbarcioğlu ve Kamuran Birand farklı fakültelerden yetiştiklerinden ayrı bir kategoride, Neda Armener ile Beyza Bilgin’i de yine kendi içinde değerlendirmek daha uygun görünmektedir. Neda Armener ve Beyza Bilgin'le yapılan röportajlar incelendiğinde bazı ortak yönlerinin bulunduğu dikkati çekmektedir: her ikisinin de kendilerini İlahiyat Fakülte'sine mensup din uzmanı akademisyenden ziyade Atatürkçü Cumhuriyet kadını olarak ön plana çıkarmaları şaşırtıcı görünmektedir. Aynı şekilde kadının toplumsal hayatta görünür olmasıyla gündeme gelen başörtü konusuna bakışlarında da başörtüsünü İslâm’nn bir emri olarak kabul etmeme açısından ortaklıkları bulundukları dikkati çekmektedir. ${ }^{55}$ Şüphesiz bu isimlerin İlahiyat tecrübesine katkıları, konumuz açısından önemli olmakla birlikte Beyza Bilgin'in orta öğretimde Din Kültürü ve Ahlak Bilgisi dersinin müfredata girmesi konusunda geçmişte katkı ve hizmetlerinin bulunduğu kabul edilmektedir. Ancak bunun dışında her ikisinin Cumhuriyet döneminde sıkça gündemde olan din ve laiklik şeklindeki tartışmadaki duruşlarıyla birbirlerine benzedikleri tespit edilmektedir. Bu dönemde dine verilen rol geleneği ve Osmanlı’yı temsil ederken laiklik ise modernliği ve ilerlemeyi çağrıştırmaktadır. Onlara doğrudan bu soruları sorma fırsatımız bulunmasa da değişik çerçevede yazıları ve röportajları incelendiğinde laikliği tercih ettikleri anlaşılmaktadır. Ankara Üniversitesi İlahiyat Fakültesi’ndeki anabilim dalları açısından dağılım incelenmeye devam edildiğinde aktif kadrolardaki bayan akademisyenlerde ağırlı̆̆ın yine Din Eğitimi, Din Psikolojisi ve İslâm Tarihi'nde olduğu tespit edilmektedir. Ancak bugün Temel İslâm Bilimleri bölümünde geçmişten farklı olarak Kelâm ve Tefsir'de birer yardımcı doçente rastlanılmaktadır. Bu bölümde uzun süre bayan öğretim elemanı bulunmaması ilginçliğini korumakta olup

55 http://www.aksiyon.com.tr/dosyalar/benim-fikirlerim-kemiklesmis-degismez-artik_515489_(24.12.2015). http://www.milliyet.com.tr/1998/01/18/t/yasam/sohbet.html (24.12.2015). 
Fakülte içi dengeler ve uygulamalar açısından daha geniş çaplı incelenmesi gerekmektedir. Eldeki verilerden hareket edince diğer bölümlerin aksine burada örneklik teşkil edecek bayan akademisyenin bulunmaması, akla gelen ilk ihtimaller arasındadır. Diğer ve daha önemli bir sebep de başörtüsünün problem olarak algılanması ve yasaklanmasıdır. Yasağın başlangıçtan beri idarî kadrolar tarafından titizlikle hayata konması, hatta özel hayata da teşmil edilecek şekilde genişletilmesi, bu kadrolara bayanların taleplerini engellemiş görünmektedir. Bir diğer zorluk da yine ilk mezunlardan Sevim Akkayảnın dinî altyapısını telafi etmek için cami görevlilerinin derslerine gitmek isteyince bayan olması engel görülerek talebinin karşılık bulmaması hali olabilir. Yani erkek öğrenciler dinî konularda fakülte içinde bulamadıkları imkânları, fakülte dışından temin ederken kız öğrencilerin aynı fırsatı yakalayamamaları, Temel İslâm Bilimleri’ndeki disiplinlere yönelmelerine engel olmuş olabilir. İşte bu sebeplerin herhangi biri veya hepsi uzun yıllar kız öğrencilerin bu bölümde akademik kariyer yapmalarını geciktirmiş görünmektedir. Ancak bütün bu esasların vakıaya yansıtacak bir esas şeklinde işlev görmesi için fakülte mezunları ve hocalarıyla daha derin araştırmadan sonra kanaate varılması daha sağlıklı olacaktır.

Marmara Üniversitesi İlahiyat Fakültesi’nde bayanların lisansüstü çalışmalarına ve akademik hayata katılımına bakıldığında iki farklı alanı birbirinden ayrı düşünmek gerekmektedir. Bendenizin Temel İslam Bilimleri bölümü Kelâm Anabilim dalında ilk bayan profesör olmam, fakülte içindeki durum ve atmosferi değerlendirmeyi mümkün kılmaktadır. Bu konunun analizini yapabilmek için 1986'dan sonraki Marmara Üniversitesi İlahiyat Fakültesi öğrencilerine bakmak gerekmektedir. Bu yıllarda mezun olan kızlar önlerinde örnek bulamadıkları halde İslâmî ilimlerin değişik dallarında yüksek lisans yapmaya başlarlar. Ancak başladıkları halde onlar içinde çalışmalarını -diğer erkek öğrenciler gibi- doktorayı bitirene kadar götürenler çok fazla değildir. Bunun sebepleri geniş bir yelpazeden incelenmeye müsait olmakla birlikte öne çıkanlar arasında genelde tüm öğrenciler için söz konusu olan maişet temini, öğretmenliğe başlayarak farklı illere tayinlerinin çıması ile akademik hayatın uzun ve meşakkatli yükünü taşıyamamak gibi durumlar sıralanabilir. Şüphesiz bu sırada lise mezunu öğrencilerin akademik alt yapı açısından -özellikle Arapça açısından- zayıf olmaları gibi sebepleri de dikkate almak gerekmektedir. O yıllarda bugün ile mukayese edildiğinde dışarıdan takviye alacak imkânların sınırlı olması da bu yolculuğu tamamlayabilme önünde ciddî bir engel oluşturmuştur. Ancak bu sırada yukarıda nakledilen İslâmcı aydınların kadın ve toplumsal hayattaki konumu hakkındaki görüşlerinin tekrar gündeme geldiği dikkati çekmektedir. Bundan dolayı kadınların Fakülte'den mezun olduktan sonra lisansüstü çalışmalara katılmaları, onların aile kurmalarını engeller mi sorusunun sorulmasına sebebiyet vermiştir. Daha önce örnekleri bulunmayan bu durum, bu yolculuğa talip olan öğrenciler açısından akıbeti belli olmayan bir macera gibi de algılanmıştır. Modeli ve örneği olmayan bu alan karşısında hocalar da birbirlerinden farklı pozisyon alarak olayı değerlendirmeye gitmişlerdir. Bir kısmı bu durumu kabul etmezken bir kısmı sessiz kalmayı yeğlerler. Ancak her halükarda bu yeni alana alışmak, bu mesleğe adım atan kızlar kadar belki onlardan daha çok hocaları açısından zor bir süreç olmuştur. Daha önce iş hayatında kadınlarla aynı mekânı paylaşmamaları, hatta onları kendilerine eşdeğer bir pozisyonda görmemeleri, yeni duruma alışmaları önünde zaman zaman engel oluşturmuştur. Bunun olabilirliğini kabul edenler açısından Ankara Üniversitesi İlahiyat Fakültesỉndeki hoca hanımlar uygulanabilirliği göstermektedir. Bu durum, 1949 ve 1959 yıllarında eğitime 
başlayan iki Fakülte’nin kuruluşundaki ortamın tekrar bayanlar açısından gündeme gelmesine vesile olmuştur. Ankara Üniversitesi İlahiyat Fakültesi'ndeki bayan akademisyenlerin konum ve fonksiyonlarına karşıllık Marmara Üniversitesi İlahiyat Fakültesi’nde de kendi bakış açıları çerçevesinde yetişecek akademik çalışma ortamın hazırlanmasının gerekliliği düşünülmeye başlanmış olmalıdır. Bu düşünceden habersiz olarak akademik çalışma hayatına atılan öğrenciler açısından önlerinde örnek alabilecekleri bayan hocaların bulunmaması, zorluğun farkına varılmasını engellemiştir. Bunun yerine onlar kadrolarda araştırma görevlisi olarak göreve başladıklarında sayılarının birden fazla olması ve aynı veya yakın dönemlerde mezun olmaları gibi sebeplerden hareketle kendi aralarında birbirilerine destek olarak yola çıkarlar. Yine bu dönemlerde fakültede İslâmî Türk Edebiyatı hocası Doç. Dr. Necla Pekolcay’ın varlığı da onlar açısından doğrudan olmasa da dolaylı bir destektir ve her şeyden önemlisi olabilirliği göstermektedir.

İlahiyat fakültelerinin ve hatta tüm din eğitimi kurumlarının misyonlarını gözden geçirip kendilerini yenilemelerine fırsat vermeksizin her on yılda bir müdahale edilmeleri, kadın akademisyen tecrübesinin de gecikmesine sebebiyet vermiştir. Nitekim fakültelerinin akademik kadroları incelendiğinde erkeklerin \%83'lük kadınların ise \%17'lik oranlarda olması (bk. Tablo 1), geçmiş sıkıntılı süreçlerden ötürü bayanların öğretim üyesi olarak varlıklarında kayda değer rakamlara ulaşamadığını göstermektedir. Aslında bunun sebepleri yukarıda tarihsel seyri açıklanırken bir anlamda dile getirilmiştir. 1990’lardan sonra başlamış ve ivme kazanmış görünen akademik hayata katılmanın hâlâ daha çok yeni olduğu gözlemlenmektedir. Rakamlar ve oranlar etki ve konumlarının çok sınırlı olduğunu ortaya koymaktaysa da 28 Şubat 1998 sürecinde yaşanan yeni müdahaleler durumu tersine çevirmiş görünmektedir. Aslında bu dönemde başörtüsü yasağ daha derin ve sert uygulanmakla birlikte kız öğrenciler açısından sevindirici dönemlere vesile olacak bir süreci de başlatmıştır. Söz konusu dönemde İmam Hatip liselerine katsayı engeli konarak öğrencilerin üniversitelere gitmelerinin engellenmesi, din eğitimi kurumlarını kız öğrencilere bırakmak durumunda kalmıştır. Diğer bir ifadeyle katsayı engeli İmam Hatip lisesi öğrencilerinin mevcudunu azaltıp düşürdügü gibi sayının büyük çoğunluğunun da kız öğrencilerden oluşmasına sebebiyet vermiş̧ir. Mütedeyyin aileler İmam Hatip liselerine meslek edinmeleri engellenmesin diye erkek çocuklarını göndermezken kız çocuklarını meslekleri olmasa da din eğitimi alsınlar diye göndermişlerdir. Bu durum, 28 Şubat süreci sonrası dönemde İmam Hatip lisesi öğrencilerinin büyük çoğunluğunun kızlardan oluşmasına, katsayı engelinden dolayı da aynı kızların İlahiyat fakültelerine gitmelerini kaçınılmaz kılmıştır. Bütün bu gelişmeler, bir zamanlar erkek olmak şartıyla engellenen kurumların kızlara terk edilmesi sonucunu doğurduğundan İmam Hatip liseleri ve İlahiyat fakültelerini kız liseleri ve fakülteleri konumuna getirmiştir. Durumun bu şekilde gelişme göstermesi, 2010 sonrası dönemde akademik kadroların da mecburen bayanlar tarafından doldurulması sonucunu doğurmuştur. Yani geçmiş muhtıra ve ihtilallar kız öğrencileri mağdur ederken son ihtilal bayanların din eğitimi kurumlarında ilk defa geçmişte örneği görülmemiş şekilde çoğalmalarına ve bu durumdan faydalanmalarına zemin hazırlamıştır. Yine Adalet ve Kalkınma Partisi döneminde üniversiteleşme oranının geçmişe göre hızla artış göstermesi ve hemen her ilde İlahiyat Fakülte’si açılması, bu kurumlarda Cumhuriyet tarihinde benzeri görülmemiş şekilde akademik personel açı̆̆ meydana getirmiştir. Yeni açılan fakültelerde ortaya çıkan ihtiyaç da kaçınılmaz olarak akademik çalışma yapan kız 
öğrencilerden karşılanmıştır. Diğer bir ifadeyle geçmiş on yılda kurumların kız öğrencilere teslim edilmesi, yeni dönemde de onların kadrolarda yer almalarının yolunu açmıştır. İstatistiklere bakılınca araştırma görevlilerinin ve yardımcı doçentlerin sayısının geçmişe göre birden hızla artmasının temelinde söz konusu saikin yattığı dikkati çekmektedir. Nitekim bu durumun genel kadrolar içindeki dağılımına bakıldığında profesör \% 2, doçent $\%$ 7, yardımcı doçent \% 11, araştırma görevlisinin \% 35’e denk gelmesi, 28 Şubat sürecinin olumlu etkisini göstermektedir.

$\mathrm{Bu}$ açıdan fakültelerdeki kadrolar incelendiğinde; tüm üniversitelerdeki İlahiyat fakültelerinde kadın profesör sayının dokuz (9) olduğu, ilk açılan yedi Fakülte'den yalnız üç tanesinde yedi bayan profesörün bulunduğu tespit edilmektedir. Söz konusu dağılım da şu şekildedir:

Ankara Üniversitesi İlahiyat Fakültesi: 3 (Din Eğitimi, Din Psikolojisi ve İslâm Tarihi),

Marmara Üniversitesi: 3 (2 Kelâm, 1 Din Eğitimi),

Konya Necmeddin Erbakan Üniversitesi: 1 (Tasavvuf Anabilim Dalı) tanedir.

Doçentlere bakıldığında tüm fakültelerdeki sayının 22 olduğu tespit edilmektedir. Bunlardan 11'i ilk yedi Fakülte'den dördünde bulunmakta olup anabilim dalları açısından dağılımı da şöyledir:

Marmara Üniversitesi: 7 (1 Hadis, 1 Arapça, 2 İslâm Tarihi, 1 Türk Din Musikisi, 1 Türk İslâm Edebiyat1, 1 Din Felsefesi),

Ankara Üniversitesi: 1 (Din Eğitimi),

Necmettin Erbakan Üniversitesi: 2 (1 Hadis ve 1 Dinler Tarihi),

İzmir Dokuz Eylül Üniversitesi: 1 (Türk İslâm Sanatları Tarihi) şeklindedir.

Diğer 11'in dağılımı da şu şekildedir:

İzmir Kâtip Çelebi Üniversitesi: 1 (Tefsir),

29 Mayıs Üniversitesi: 1 (Dinler Tarihi),

Kars Kafkas Üniversitesi: 1 (Din Sosyolojisi),

Bartın Üniversitesi İslâmî İlimler Fakültesi: 1 (Dinler Tarihi),

Adana Çukurova Üniversitesi: 2 (Türk İslâm Edebiyatı ile İslâm Tarihi ve Sanatları),

Diyarbakır Dicle Üniversitesi: 1 (Dinler Tarihi),

Eskişehir Osman Gazi Üniversitesi: 1 (Tefsir),

Isparta Süleyman Demirel Üniversitesi: 2 (İslâm Felsefesi ve Mantık),

İstanbul Üniversitesi: 1 (Din Eğitimi) şeklindedir.

Yardımcı doçent sayısına baktığımızda sayılarının 116 olduğu, bunlardan ilk yedi üniversitedeki sayının da 21’e tekabül ettiği dikkati çekmektedir. Söz konusu dağılım da şu şekildedir: 
Ankara Üniversitesi: 7 (2 Din Eğitimi, 2 Din Psikolojisi, 1 İslâm Tarihi, 1 Tefsir 1 Kelâm),

Marmara Üniversitesi: 9 (2 Din Eğitimi, 2 Din Sosyolojisi, 2 İslâm Tarihi, 1 Hadis, 1 Felsefe Tarihi 1 Din Psikolojisi),

Samsun Ondokuz Mayıs Üniversitesi: 1 (Kiraat),

Kayseri Erciyes Üniversitesi: 1 (İslâm Tarihi),

Erzurum Atatürk Üniversitesi: 3 (2 Türk İslâm Edebiyatı, 1 Tefsir) tanedir.

Araştırma Görevlisi sayısı da 389'dur. Ancak ilk olarak açılan yedi Yüksek İslâm Enstitüsü'nün durumu incelendiğinde yukarıdaki rakamlardan da anlaşıldığg üzere Marmara Üniversitesi haricindekilerin bayan akademisyen açısından farklı bir konumda olduğunu söylemek mümkün görünmemektedir. Ankara ve Marmara Üniversitesi şeklindeki farklılaşma bu konuda da devam edecek tarzdadır. Kayda değer rakam açısından bakıldığında Isparta Süleyman Demirel Üniversitesi İlahiyat Fakültesi’nin daha önce açılan İzmir, Bursa, Samsun, Konya gibi ilk yedi içindeki Yüksek İslâm enstitülerinden çok daha fazla bayan akademisyen bulundurduğu dikkati çekmektedir. 1 Profesör, 2 Doçent, 5 Yrd. Doçent, 15 Araştırma görevlisiyle burada toplam 23 kişilik bayan akademisyenin varlığı, akla Isparta İmam Hatip’teki havanın devam ettiği izlenimini vermektedir. Bu konuda daha sağlıklı ve net bir sonuca varmak için konunun -kurucu dekanın katkısı da dikkate alınarak- daha geniş çerçeveden incelenmesini gerektirmektedir. Bu hususta dikkati çeken diğer bir fakülte de Sakarya Üniversitesi İlahiyat Fakültesi'dir. Buradaki bayan akademisyen sayısının toplam 20'ye ulaşması, dağılımın da 1 Yrd. Doç. 3 Öğretim Görevlisi, 16 Araştırma Görevlisi şeklinde olması buranın da yakından araştırılmasını kaçınılmaz kılmaktadır. 3 Öğretim Görevlisinin Arap Dili ve Belağatı Anabilim dalından olması yeni dönemde hazırlık sınıflarının yeniden uygulamaya konması ve öğrenci sayısının hızlı artış göstermesi gibi sebeplerden doğan ihtiyacın cinsiyet ayrımına gidilmeksizin karşılandığını akla getirmektedir. 16 Araştırma görevlisinden on tanesinin (ÖYP) Öğretim Üyesi Yetiştirme Programı sonucunda merkezi olarak yerleştirilmesi, meselenin fakülte dışındaki faktörler dikkate alınarak yorumlanabileceğini akla getirmektedir. Fakültenin mekân olarak İstanbul gibi merkezî yerlere yakınlığının bulunması, tercih edilebilirliğini arttırmış görünmektedir. Büyük şehirlerin ilmî imkânlarının fazla olması gibi sebepler buralardaki fakültelerin daha fazla tercih edilmelerini sağlamaktadır. Nitekim tarihi çok gerilere gitmeyen İstanbul Üniversitesi İlahiyat Fakültesi'ndeki sayısının da kısa sürede 22'ye ulaşması, aynı faktörü akla getirmektedir.

Bayan akademisyenler içerisinde araştırma görevlisi oranının hızla yükseliş göstererek \% 67’ye çıkması bunun genel içinde de 35’e yükselmesine sebebiyet vermiştir. Söz konusu durum analiz edildiğinde şu hususlar ön plana çıkmaktadır: Birinci ve belki en önemli sebep, hızla açılan İlahiyat fakültelerinde doğan akademik kadro ihtiyacı, tercih kriterlerini asgarî düzeye indirgeyerek seçici olmayı devre dışı bırakmıştır. Bu durum tercihte bayan akademisyen almak istenmese de fakülteler bu konuda mecbur kalmışlardır. Diğer önemli bir neden de araştırma görevlisi kadrolarının (ÖYP) Öğretim Üyesi Yerleştirme Programıyla merkezî olarak yapılmasıdır. Burada yukarıda bahsi geçen 28 Şubat sonrasında katsayı engeli ve İmam Hatip liselerinin üniversiteye gidişlerinin önünün kapanması durumunu yeniden gündeme almak gerekmektedir. Bu engel hem fakültelerdeki kız öğrenci sayısının 
artmasını, hem de başarı açısından kızların az sayıdaki erkek öğrenciden çok daha fazla ön plana çımalarına sebebiyet vermiştir. Bu gibi hususlar 2010 yılından itibaren açılan fakültelerdeki ihtiyacın cinsiyet ayrımına gidilmeksizin kız öğrenciler tarafından karşılanmasını gerekli kıldığını ortaya koymaktadır.

Burada yeri gelmişken bayan akademisyen tercih etmeme nedenlerine yakından baktığımızda dikkate alınabilecek iki faktör öne çıkmaktadır. Bunlardan biri ve en önemlisi, kadın ve erkek arasında insanlığın başlangıcından beri var olan tarafgir bakış açısıdır. Desteklediğini söylese bile erkekler çoğu zaman bulunduğu ortamda farkına varsın veya varmasın kadınların bulunmasını tercih etmemektedirler. Diğer bir sebep de Osmanlı İslâmcılarının kadının sosyal hayata katılmasına aile hayatını aksatmamak kaydıyla verdiği ruhsatın bu konuda devamlılık arzetmesidir. Kadının yoğun akademik hayata katılması evlenmesini veya aile hayatı kurmasını aksatacağı, endişe edilen konular arasındaki yerini korumaktadır. Bu kaygının temelinde de ailede erkek ve kadın arasındaki geleneksel rollerin değişmemesi veya kadının ev içi sorumluluğu tümüyle üstlenmesinin beklenmesi, kadının akademik hayata katılmasını zorlaştırmaktadır. Söz konusu ağır şartlar da kadınların aile ve akademik hayat ikileminde kalmasına, ikisinden birini tercih etmesi veya edememesi gibi ihtimaller arasında sıkışmasına sebebiyet vermektedir.

Bayan akademisyenlerin fakülteler içindeki bölümlerdeki dağılımlarına bakıldığında \%51'lik oranla Temel İslâm Bilimlerinin önde gittiği görülmektedir. Ancak bu durum gerçekte oranın çok yüksek gibi görünmekle birlikte iyi analiz edildiğinde farklı şekilde yorumlanmaya müsait olduğunu göstermektedir. Temel İslâm Bilimlerinin en büyük bölüm olması, içindeki anabilim dalı ve mensubu sayısının da çok olmasına sebebiyet vermektedir. Diğer bir ifadeyle bu bölümün fakültelerdeki ders sayısının fazlalığı, buradaki hoca kadrosunun da diğer bölümlere göre daha fazla olmasını gerektirmektedir. Diğer önemli bir faktör de bölümdeki Arap Dili ve Belağatı Anabilim dalının bir anabilim dalı sınırlarını aşacak kapasiteye sahip olmasıdır. Hazırlık sınıflarında dil eğitimi verilmesi, sınıf ve dolayısıyla hoca sayısının da diğer anabilim dallarıyla mukayese edilmeyecek kadar fazla olmasını kaçınılmaz kılmaktadır. Nitekim kadın akademisyen sayısının bu bölümde Temel İslâm Bilimleri içindeki \% 20'lik payla en yüksek orana ulaşmasının temelinde de bu yatmaktadır (bk. Tablo 4). Nitekim Felsefe Din Bilimleri (bk. Tablo 7) ile İslâm Tarihi ve Sanatları bölümlerindeki araştırma görevlisi (bk. Tablo 9) oranlarının \% 63’e denk gelmesine karşılık Temel İslâm Bilimlerinde bu sayının \% 71’e (bk. Tablo 5) ulaşması da yukarıda zikri geçen sebeplerden kaynaklanmaktadır.

İlk açılan Yüksek İslâm enstitülerinin devamı mahiyetindeki 7 fakülte ayrıca incelenmiş olmakla birlikte Ankara ve İstanbul dışındakilerin bayan akademisyen oranları açısından diğer fakültelerden kayda değer bir farklılıklarının olduğunu söylemek zordur. Bunlar içinde özellikle Marmara ve Ankarảnın eskisi kadar olmasa da geçmişten gelen farklılaşmayı nispeten devam ettirdikleri ve bu durumun bayan akademisyenlere de yansıdığ 1 dikkati çekmektedir. Söz konusu faklılaşma geçmişe göre giderek azalma gösterse de konu belli açılardan hala hayatiyetini korumaktadır. Meselâ Ankara Üniversitesi İlahiyat Fakültesi’ndeki başörtüsü konusundaki bakış açıları araştırma görevlileri açısından değişse de diğer kadrolarda geçmiş bakış açısının devam ettiği gözlemlenmektedir. Kadın akademisyen sayısı açısından geçmiş tecrübesi bulunan Ankara Üniversitesi İlahiyat Fakültesi’nin (3 profesör, 
1 doçent, 7 Yrd. Doç) Marmara’ya göre (3 profesör, 7 doçent, 9 Yrd. Doç.) daha durağan gözüktüğ̈u, bu konuda Marmara’nın özellikle doçent ve yardımcı doçent kadroları açısından daha ileride olduğu dikkati çekmektedir. Araştırma görevlisi açısından ise Ankara'daki sayının Marmara’dakinden daha fazla olduğu tespit edilmektedir.

Fakültelerin kuruluşlarından günümüze kadar durumlarının her an dış müdahaleye açık olması, onların öngördükleri hedefleri gerçekleştirebilecek zemine ulaşmalarını engellemektedir. Kadınların din eğitimi kurumlarına katkısı da kısıtlamalardan dolayı çok ağır adımlarla ilerlemektedir. Ancak ileride fakültelere müdahale edilmez ve kendi kaderlerini kendileri çizebilecekleri normal zeminlere geçebilirlerse mevcut potansiyelleri, istenilen hedefe ulaşmada geçmişleriyle mukayese edilemeyecek yerlere geleceklerinden şüphe edilmemektedir. Ancak hâlâ önlerinde çözmeleri gereken çok ciddi meseleler bulunmaktadır. Modernleşme tecrübesinde önemli bir konumu bulunan kadınların din eğitimi tecrübesine katılmaları, laik Cumhuriyetin toplumla buluşabilmesi ve toplumsal tabana inebilmesi açısından büyük bir şanstır. Böylesi bir avantaj, büyük mücadelelerden sonra bu kurumların normalleşme zeminine ulaşmasıyla mümkün olmuştur. Ancak mevcut durum gerek eğitim-öğretim, gerekse akademik kadrolar açısından müdahale edilmediği takdirde gelecekte daha iyi düzeye gelebilme kapasitesini barındırmaktadır. Şüphesiz bu aşamalarda kadın akademisyenlerin varlı̆̆ı ve misyonu da bugüne göre daha fazla olacaktır. 


\section{Kaynaklar}

Abdullah Cevdet, “Müşterek Terbiye, Tevhîd-i Tedrîsat”, İctihâd, İstanbul 1924, XIX, sy. 168, s. 3397-3402. Aksekili, Ahmed Hamdi, “Din Tedrisatı ve Din Müesseseleri Hakkında Rapor”, Cumhuriyet Türkiyesinde Bir Mesele olarak Din (haz. İsmail Kara), İstanbul 2008; Dergah Yay.

Altıkulaç, Tayyar, Zorlukları Aşarken, İstanbul 2012; Ufuk Yay.

Ayhan, Halis “İlahiyat”, DİA, XXII, 70-72.

Ayhan, Halis “İmam Hatip Lisesi”, DİA, XXII, 191-194.

Ayhan, Halis Türkiye'de Din Eğitimi, İstanbul 2014; MÜİFAV.

Baltacıoğlu, İsmayıl Hakkı, Hayatım (haz. Ali Y. Baltacıoğlu), İstanbul 1998; Dünya Yayınları.

Başgil, Ali Fuad, Din ve Laiklik, İstanbul 1991; Yağmur Yay.

Çaha, Ömer, Sivil Kadın, Ankara 1996; Vadi Yay.

Göle, Nilüfer, Modern Mahrem, İstanbul 1993; Metis Yay.

Güngör, Erol, İslâm’n Bugünkü Meseleleri, İstanbul 1989; Ötüken Neşriyat.

Kara, İsmail, Cumhuriyet Türkiyesinde Bir Mesele Olarak İslâm, İstanbul 2008; Dergah Yay.

M. Ferid Vecdi, "Müslüman Kadını: Dokuzuncu Fasıl: Tesettür Kadınların Nişâne-i Esâreti midir, Yoksa Zamin-i Hürriyeti midir?” Sırât-ı Müstakîm, İstanbul, 1324, I, sy. 11, s. 173-176.

M. Ferid Vecdi, “Tesettür Kadınların İktisâb-1 Kemâl Etmelerine Mâni“ midir?” Sırât-ı Müstakîm, I, sy. 13, s. 203-205.

M. Ferid Vecdi, “Tesettür Kalkar mı” Strât-ı Müstakîm I, sy. 15, s. 234-236.

M. Ferid Vecdi, “Yine Tesettür Meselesi” Sebîlürreşâd, XI, sy. 276, s. 241-243.

Meriç, Nevin, Dindar Bir Doktor Hanım: Ayşe Hümeyra Ökten, İstanbul, 2011; Timaş Yay.

Öcal, Mustafa Bozok Imam Hatip Mektebinden Yozgat İmam Hatip Liselerine, Bursa 2015; YİMEV.

Öcal, Mustafa "Kuruluşundan Günümüze İmam Hatip Liseleri”, Din Eğitimi Araştırmaları Dergisi, 1999, sy. 6, s. 201-254.

Öcal, Mustafa, Tanıkların Dilinden Cumhuriyet Dönemi Din Eğitimi ve Dini Hayat, İstanbul 2008, I-III, Ensar Neşriyat.

Öğrenci Seçme ve Yerleştirme Sınavı 1985 İkinci Basamak Kılavuzu.

Öğrenci Seçme ve Yerleştirme Sınav 1987 İkinci Basamak Kılavuzu.

Öğrenci Seçme ve Yerleştirme Sınav 1989 İkinci Basamak Kılavuzu.

Öğrenci Seçme ve Yerleştirme Sınav 1990 İkinci Basamak Kılavuzu.

Öztürk, Veli, “İlahiyat Fakülteleri ile Diyanet İşleri Başkanlığı 1 ve Millî Eğitim Bakanlığı Arasındaki İlişkilerin Tarihî Gelişimi Bağlamında Bazı Çözüm Önerileri”, Türkiye’de Yüksek Din Eğitiminin Sorunları, Yeniden Yapılanması ve Geleceği Sempozyumu, Isparta 2004: S,D.Ü. İlahiyat Fakültesi Yay. s. 105-142.

Sitembölükbaşı, Şaban Türkiye'de İslâm’n Yeniden İnkişafı, Ankara 1995; TDV İSAM Yay.

Türk Din Sosyolojisinde Mehmet Rami Ayas (haz. Kevser Gülçiçek Ayas-Ali Akyurt), İstanbul 2012; İz Yay. http://www.aksiyon.com.tr/dosyalar/benim-fikirlerim-kemiklesmis-degismez-artik_515489_(24.12.2015). http://www.belgehaber.com/haber.php?haber_id=3753 (24.12.2015).

http://www.buyuktorbali.com/lisede-sapkali-ogrenciler/ (13,12,2016).

http://bianet.org/bianet/siyaset/107522-1968-de-basortusu-ilk-fakulte-isgali-80-lerde-turban-ve-kenanevren (15.12. 2016).

http://www.cumhuriyet.com.tr/haber/diger/184516/Turban_tartismalari_60_larda_baslamisti.html\# (15.12. 2016).

http://www.milliyet.com.tr/1998/01/18/t/yasam/sohbet.html (24.12.2015).

http://www.risalehaber.com/zubeyir-abi-babacan-boykotunu-destekledi-122214h.htm (24.12.2015). 
EKLER: ${ }^{56}$

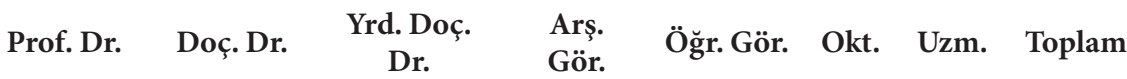

\begin{tabular}{|l|c|c|c|c|c|c|c|c|}
\hline Kadın & 9 & 22 & 116 & 389 & 33 & 6 & 5 & 580 \\
Erkek & 581 & 281 & 916 & 720 & 335 & 62 & 7 & 2902 \\
\hline Toplam & 590 & 303 & 1032 & 1109 & 368 & 68 & 12 & 3482 \\
\hline
\end{tabular}

\section{Genel Dağılım}
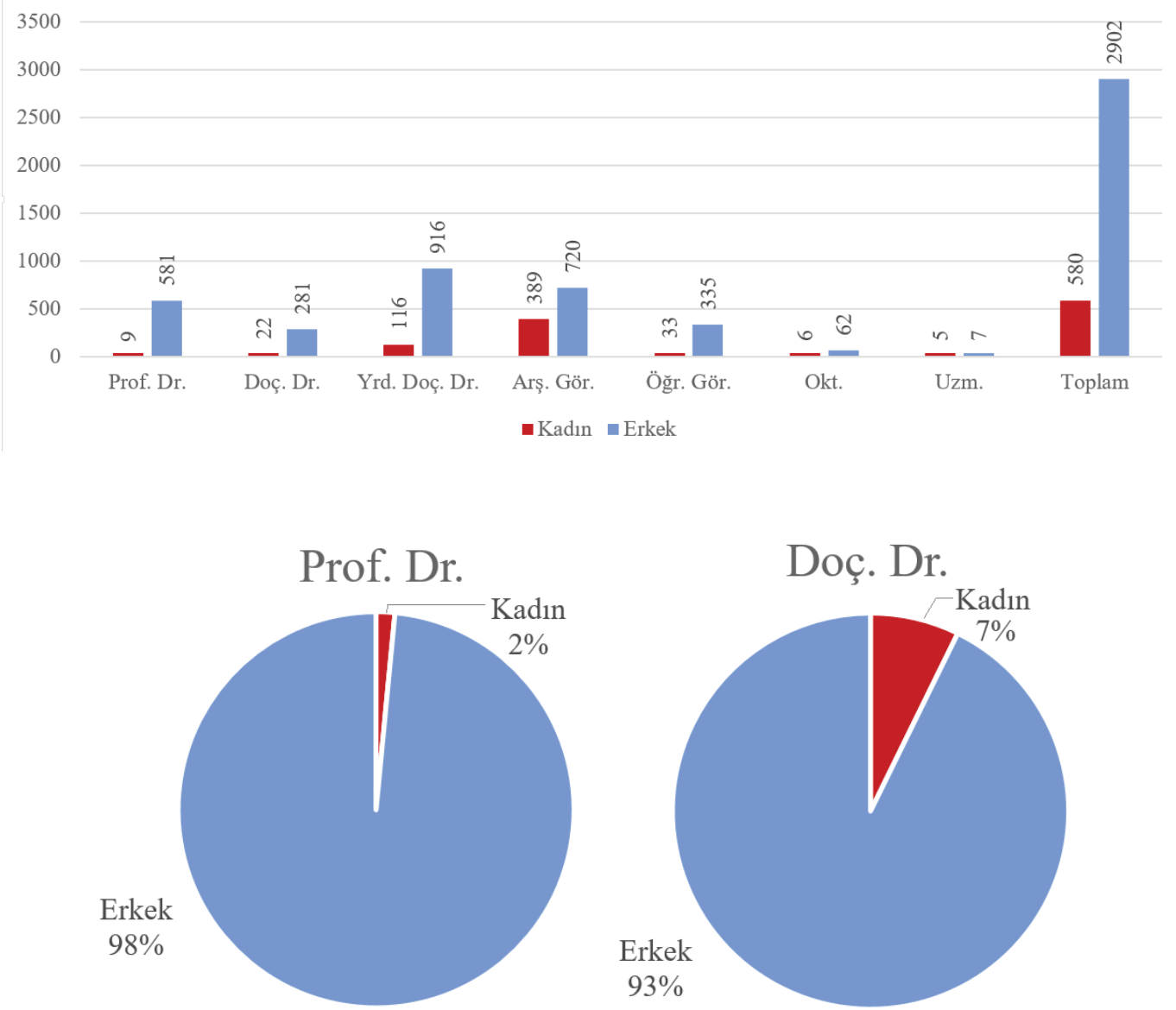

56 Fakültelerin durumu tespit edilirken Şubat 2016 tarihi esas alınmıștır. Dolayısıyla bu tarihten sonraki gelişmeler listelere ve istatistiklere yansımamıştır. Söz konusu listelerin tespitinde ve tasnifinde katkılarından dolayı araştırma görevlileri Tuğba Dumangöz, Osman Sezgin ve Ahmet Şenharputlu'ya, verileri istatiksel hale getirmedeki desteklerinden dolayı da Arş. Gör. Bilal Kır’a müteşekkirim. 

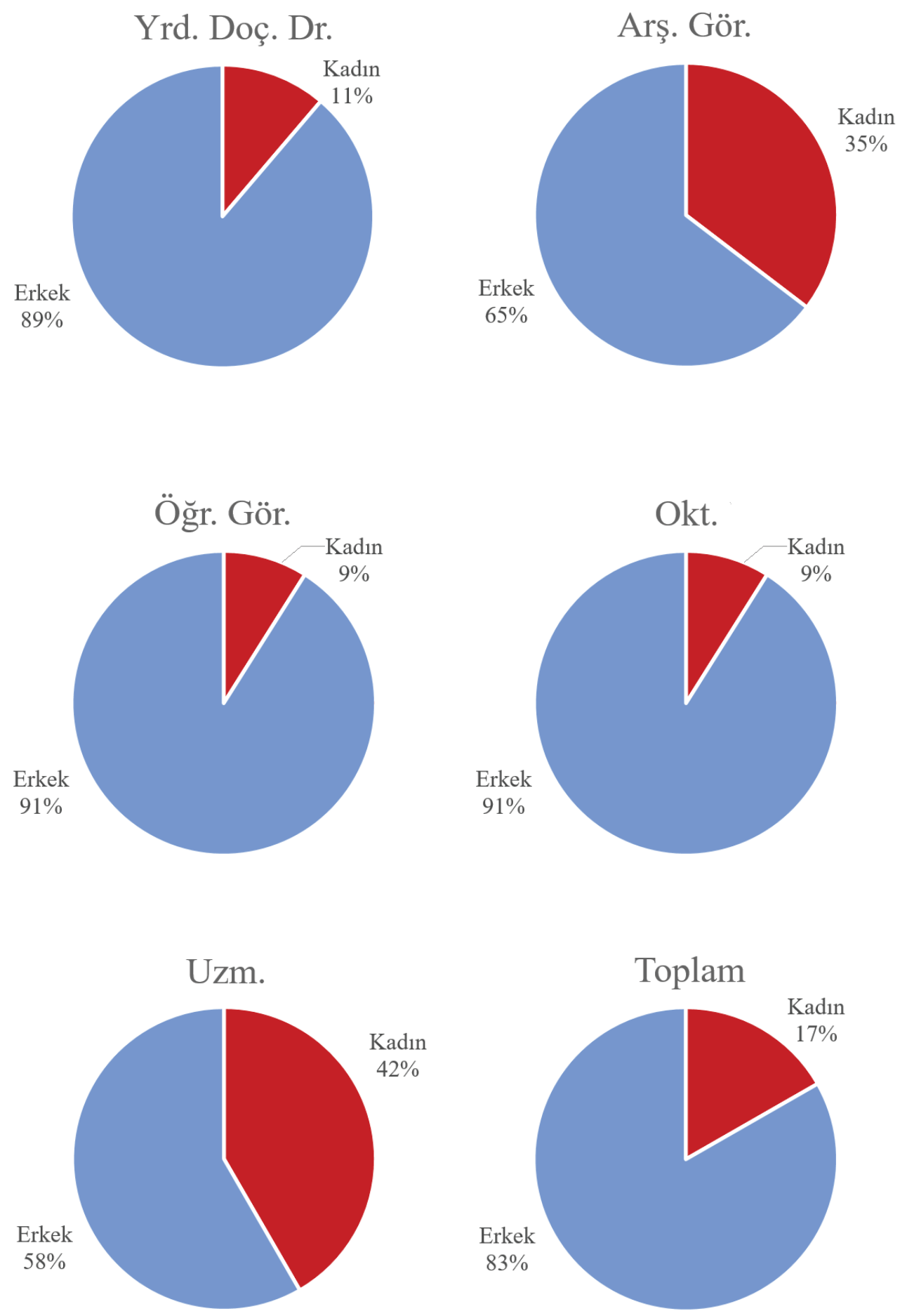
Tablo 2 Kadın Akademisyenlerin Unvan Dağılımı ve Kendi İçindeki Yüzdelikleri

\begin{tabular}{|l|c|c|}
\hline Prof. Dr. & 9 & $1,55 \%$ \\
\hline Doç. Dr. & 22 & $3,79 \%$ \\
\hline Yrd. Doç. Dr. & 116 & $20 \%$ \\
\hline Arş. Gör. & 389 & $67,07 \%$ \\
\hline Öğr. Gör. & 33 & $5,69 \%$ \\
\hline Uzm. & 5 & $0,86 \%$ \\
\hline Okt. & 6 & $1,03 \%$ \\
\hline Toplam & $\mathbf{5 8 0}$ & $\mathbf{1 0 0} \%$ \\
\hline
\end{tabular}

Kadın Akademisyenlerin Unvan Dağılımı

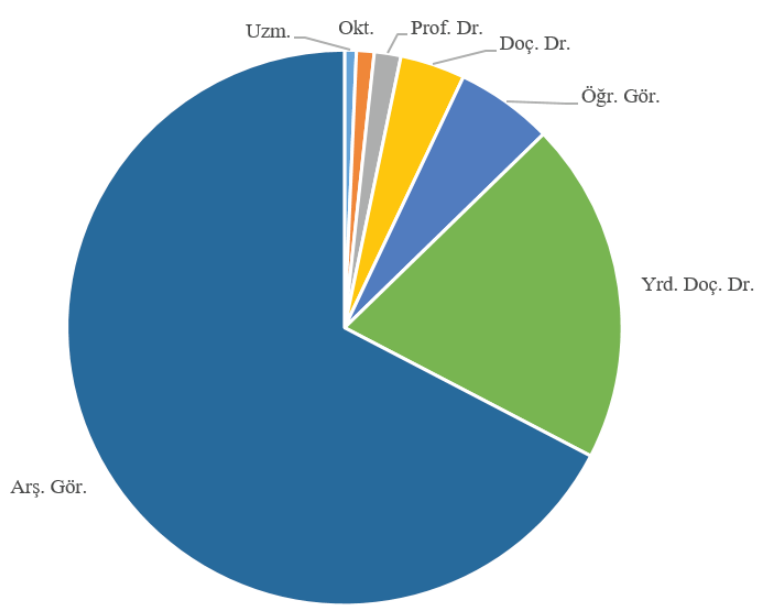


Tablo 3 Kadınların Anabilim Dalları İçindeki Dağılımları

\begin{tabular}{|c|c|c|c|c|c|c|c|c|}
\hline ABD / Unvan & ث்َ & $\begin{array}{l}\dot{\Delta} \\
\dot{0} \\
\dot{0}\end{array}$ & 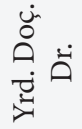 & 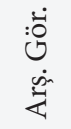 & 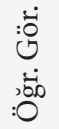 & $\frac{\dot{y}}{0}$ & $\underset{\mathbb{N}}{\stackrel{N}{\Delta}}$ & $\frac{\Xi}{\frac{\pi}{2}}$ \\
\hline Temel İslâm Bilimleri & 4 & 5 & 52 & 211 & 19 & 5 & 1 & 297 \\
\hline Arap Dili ve Belagatı & 1 & 1 & 8 & 38 & 6 & 5 & - & 59 \\
\hline Hadis & - & 2 & 7 & 38 & - & - & - & 47 \\
\hline İslâm Hukuku & - & - & 7 & 32 & 1 & - & - & 40 \\
\hline Kelâm & 2 & - & 8 & 26 & 1 & - & - & 37 \\
\hline Kiraat & - & - & 1 & 2 & 8 & - & - & 11 \\
\hline Mezhepler Tarihi & - & - & 1 & 11 & - & - & - & 12 \\
\hline Tasavvuf & 1 & - & 12 & 29 & 1 & - & - & 43 \\
\hline Tefsir & - & 2 & 8 & 35 & 2 & - & 1 & 48 \\
\hline Felsefe ve Din Bilimleri & 3 & 10 & 41 & 112 & 8 & 1 & 3 & 178 \\
\hline Din Bilimleri & - & - & 3 & 10 & 2 & - & - & 15 \\
\hline Din Eğitimi & 2 & 2 & 11 & 19 & 2 & - & 1 & 37 \\
\hline Din Felsefesi & - & 2 & - & 9 & 1 & - & - & 12 \\
\hline Din Psikolojisi & 1 & - & 11 & 11 & - & 1 & 1 & 25 \\
\hline Din Sosyolojisi & - & 1 & 6 & 17 & 1 & - & - & 25 \\
\hline Dinler Tarihi & - & 4 & 3 & 15 & 1 & - & - & 23 \\
\hline Felsefe Tarihi & - & - & 2 & 9 & - & - & - & 11 \\
\hline İslâm Felsefesi & - & - & 5 & 19 & 1 & - & 1 & 26 \\
\hline Mantık & - & 1 & - & 3 & - & - & - & 4 \\
\hline İslam Tarihi ve Sanatları & 2 & 7 & 21 & 60 & 6 & - & - & 96 \\
\hline İslâm Tarihi & 1 & 3 & 10 & 29 & - & - & - & 43 \\
\hline Türk Din Musikisi & - & 1 & - & 2 & 1 & - & - & 4 \\
\hline Türk İslâm Edebiyatı & - & 2 & 8 & 21 & 3 & - & - & 34 \\
\hline Türk İslâm Sanatları & 1 & 1 & 3 & 8 & 2 & - & - & 15 \\
\hline İDKAB & - & - & 2 & 6 & - & - & 1 & 9 \\
\hline Dinler Tarihi & - & - & - & 1 & - & - & - & 1 \\
\hline İDKAB & - & - & 2 & 5 & - & - & 1 & 8 \\
\hline TOPLAM & 9 & 22 & 116 & 389 & 33 & 6 & 5 & 580 \\
\hline
\end{tabular}




\begin{tabular}{|c|c|c|c|c|c|c|c|c|}
\hline ABD / Unvan & $\begin{array}{l}\dot{H} \\
\stackrel{H}{0} \\
\dot{0} \\
\dot{2}\end{array}$ & $\begin{array}{l}\dot{\vec{D}} \\
\dot{\leftrightarrow} \\
\dot{\circ}\end{array}$ & 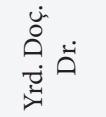 & 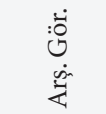 & $\begin{array}{l}\dot{0} \\
\dot{0} \\
\dot{0}, 0 \\
: 0\end{array}$ & $\frac{\dot{*}}{0}$ & 空 & $\frac{\tilde{\Xi}}{\frac{\tilde{J}}{2}}$ \\
\hline Temel İslâm Bilimleri & $0,69 \%$ & $0,86 \%$ & $8,97 \%$ & $36,38 \%$ & $3,28 \%$ & $0,86 \%$ & $0,17 \%$ & $51,12 \%$ \\
\hline Arap Dili ve Belagatı & $0,17 \%$ & $0,17 \%$ & $1,38 \%$ & $6,55 \%$ & $1,03 \%$ & $0,86 \%$ & - & $10,19 \%$ \\
\hline Hadis & - & $0,34 \%$ & $1,21 \%$ & $6,55 \%$ & - & - & - & $7,94 \%$ \\
\hline İslâm Hukuku & - & - & $1,21 \%$ & $5,52 \%$ & $0,17 \%$ & - & - & $6,91 \%$ \\
\hline Kelâm & $0,34 \%$ & - & $1,38 \%$ & $4,48 \%$ & $0,17 \%$ & - & - & $6,39 \%$ \\
\hline Kuraat & - & - & $0,17 \%$ & $0,34 \%$ & $1,38 \%$ & - & - & $1,90 \%$ \\
\hline Mezhepler Tarihi & - & - & $0,17 \%$ & $1,90 \%$ & - & - & - & $2,07 \%$ \\
\hline Tasavvuf & $0,17 \%$ & - & $2,07 \%$ & $5,00 \%$ & $0,17 \%$ & - & - & $7,43 \%$ \\
\hline Tefsir & - & $0,34 \%$ & $1,38 \%$ & $6,03 \%$ & $0,34 \%$ & - & $0,17 \%$ & $8,29 \%$ \\
\hline Felsefe ve Din Bilimleri & $0,52 \%$ & $1,72 \%$ & $7,07 \%$ & $19,31 \%$ & $1,38 \%$ & $0,17 \%$ & $0,52 \%$ & $30,74 \%$ \\
\hline Din Bilimleri & - & - & $0,52 \%$ & $1,72 \%$ & $0,34 \%$ & - & - & $2,59 \%$ \\
\hline Din Eğitimi & $0,34 \%$ & $0,34 \%$ & $1,90 \%$ & $3,28 \%$ & $0,34 \%$ & - & $0,17 \%$ & $6,39 \%$ \\
\hline Din Felsefesi & - & $0,34 \%$ & - & $1,55 \%$ & $0,17 \%$ & - & - & $2,07 \%$ \\
\hline Din Psikolojisi & $0,17 \%$ & - & $1,90 \%$ & $1,90 \%$ & - & $0,17 \%$ & $0,17 \%$ & $4,32 \%$ \\
\hline Din Sosyolojisi & - & $0,17 \%$ & $1,03 \%$ & $2,93 \%$ & $0,17 \%$ & - & - & $4,32 \%$ \\
\hline Dinler Tarihi & - & $0,69 \%$ & $0,52 \%$ & $2,59 \%$ & $0,17 \%$ & - & - & $3,97 \%$ \\
\hline Felsefe Tarihi & - & - & $0,34 \%$ & $1,55 \%$ & - & - & - & $1,90 \%$ \\
\hline İslâm Felsefesi & - & - & $0,86 \%$ & $3,28 \%$ & $0,17 \%$ & - & $0,17 \%$ & $4,49 \%$ \\
\hline Mantık & - & $0,17 \%$ & - & $0,52 \%$ & - & - & - & $0,69 \%$ \\
\hline İslâm Tarihi ve Sanatları & $0,34 \%$ & $1,21 \%$ & $3,62 \%$ & $10,34 \%$ & $1,03 \%$ & - & - & $16,58 \%$ \\
\hline İslâm Tarihi & $0,17 \%$ & $0,52 \%$ & $1,72 \%$ & $5,00 \%$ & - & - & - & $7,43 \%$ \\
\hline Türk Din Musikisi & - & $0,17 \%$ & - & $0,34 \%$ & $0,17 \%$ & - & - & $0,69 \%$ \\
\hline Türk İslâm Edebiyatı & - & $0,34 \%$ & $1,38 \%$ & $3,62 \%$ & $0,52 \%$ & - & - & $5,87 \%$ \\
\hline Türk İslâm Sanatları & $0,17 \%$ & $0,17 \%$ & $0,52 \%$ & $1,38 \%$ & $0,34 \%$ & - & - & $2,59 \%$ \\
\hline İDKAB & - & - & $0,34 \%$ & $1,03 \%$ & - & - & $0,17 \%$ & $1,55 \%$ \\
\hline Dinler Tarihi & - & - & - & $0,17 \%$ & - & - & - & $0,17 \%$ \\
\hline İDKAB & - & - & $0,34 \%$ & $0,86 \%$ & - & - & $0,17 \%$ & $1,38 \%$ \\
\hline TOPLAM & $1,55 \%$ & $3,79 \%$ & $20,00 \%$ & $67,07 \%$ & $5,69 \%$ & $1,03 \%$ & $0,86 \%$ & $100 \%$ \\
\hline
\end{tabular}




\section{Kadın Akademisyenlerin ABD Dağılımı}

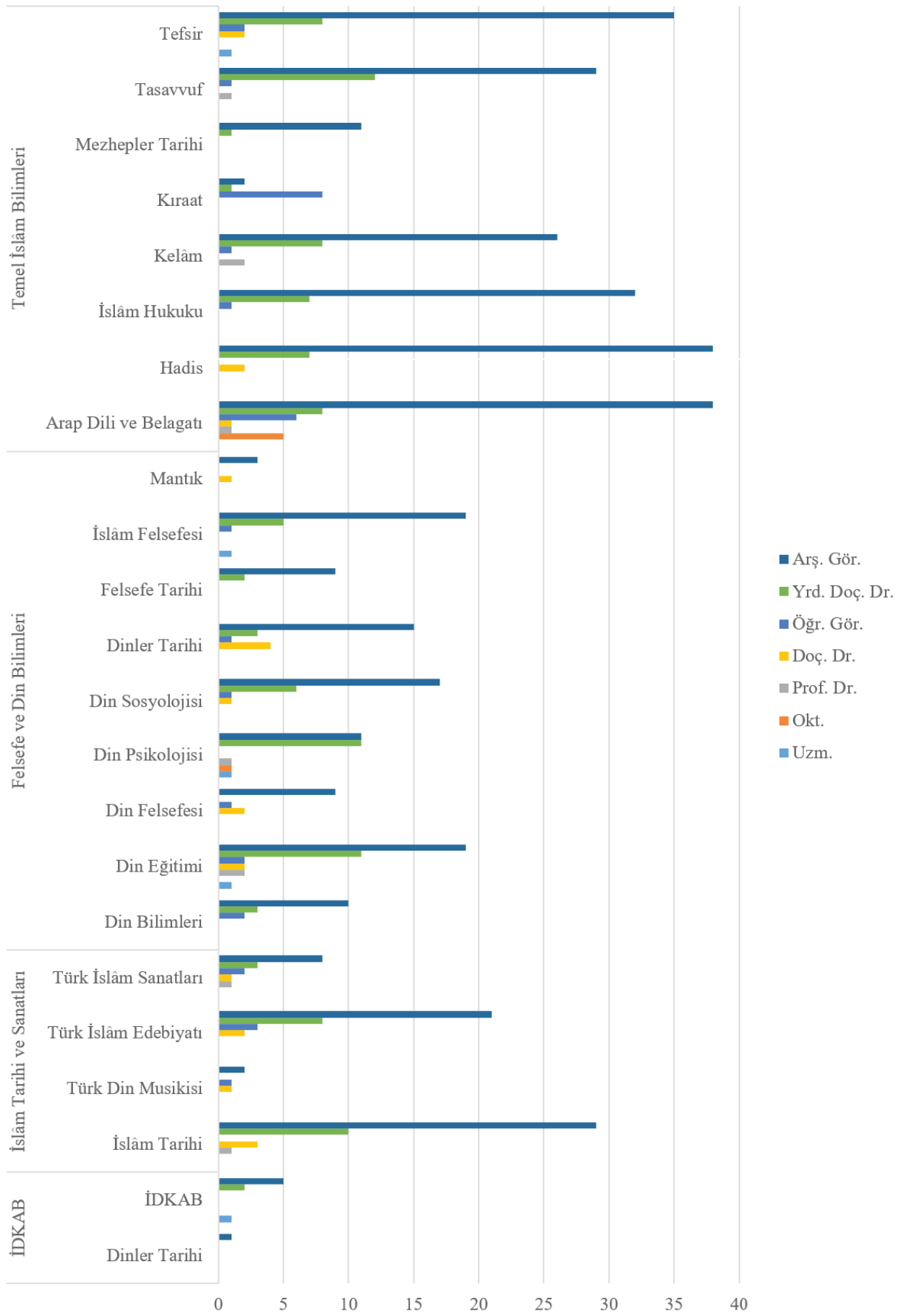


Kadın Akademisyenlerin ABD Dağılımı (Öğr. Gör., Okt., Uzm. hariç)

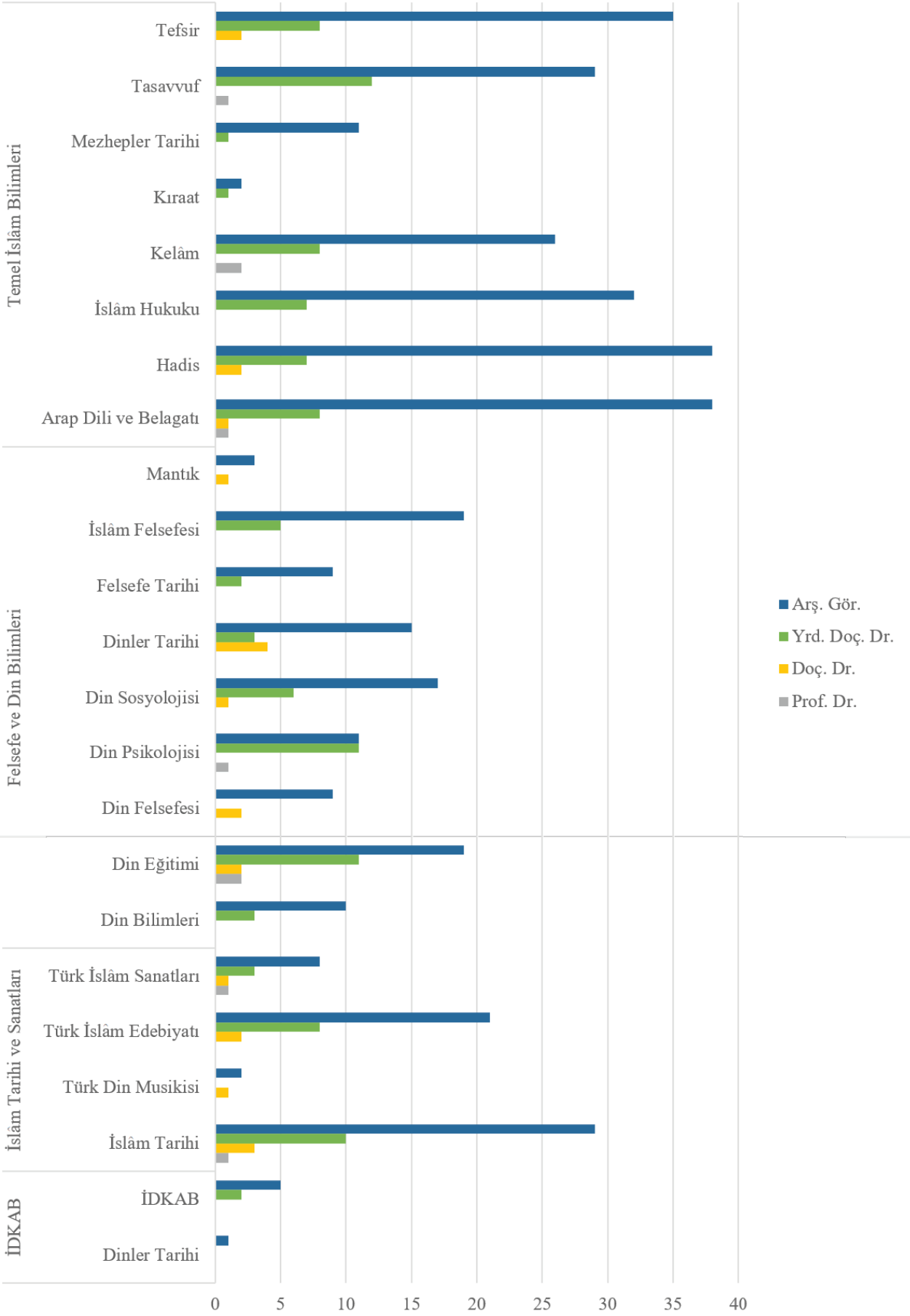


Kadın Akademisyenlerin ABD Dağılımı (Arş. Gör., Öğr. Gör., Okt., Uzm. hariç)

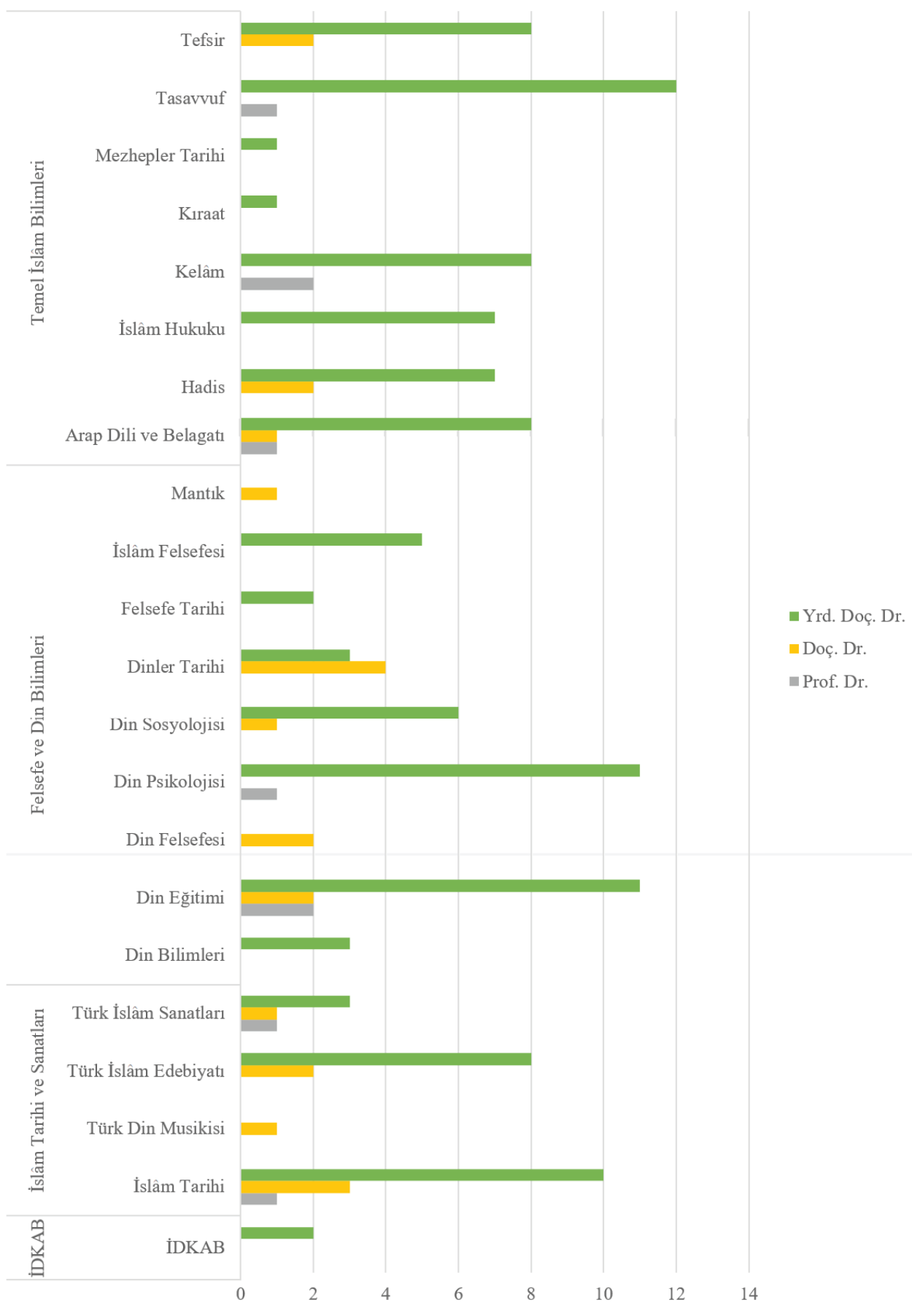




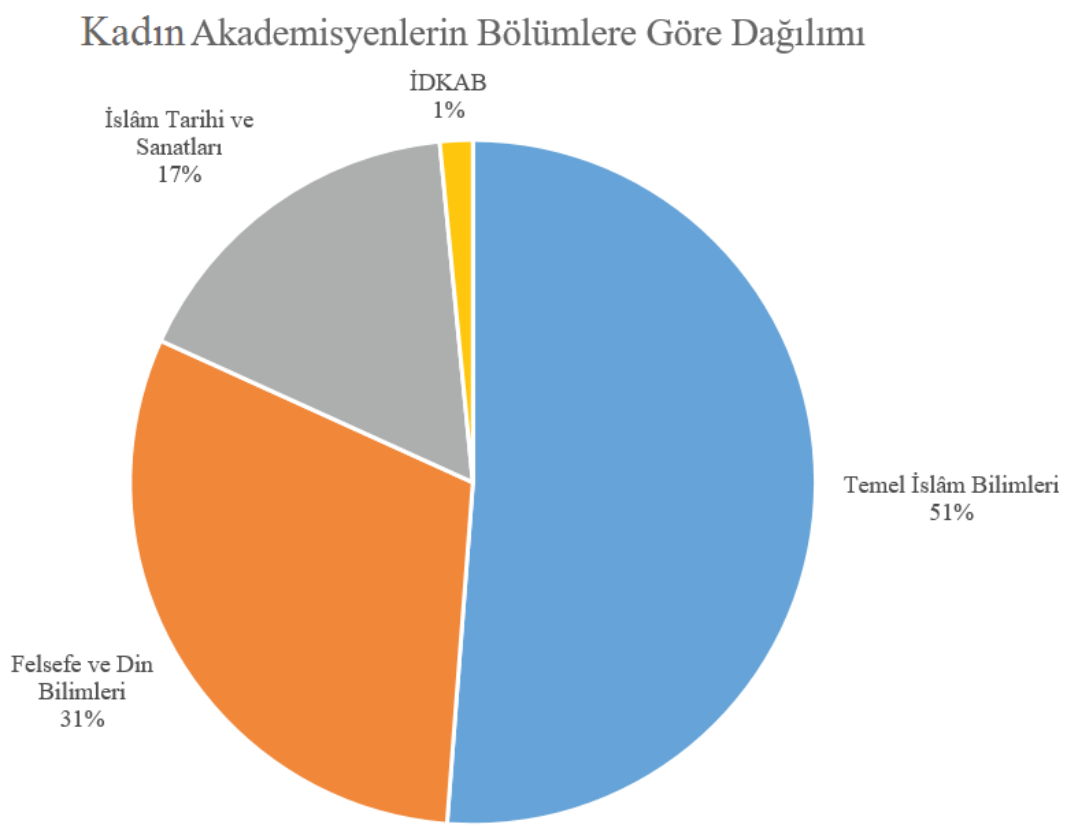

Tablo 4: Kadın Akademisyenlerin Temel İslâm Bilimleri ABD Dağılımı

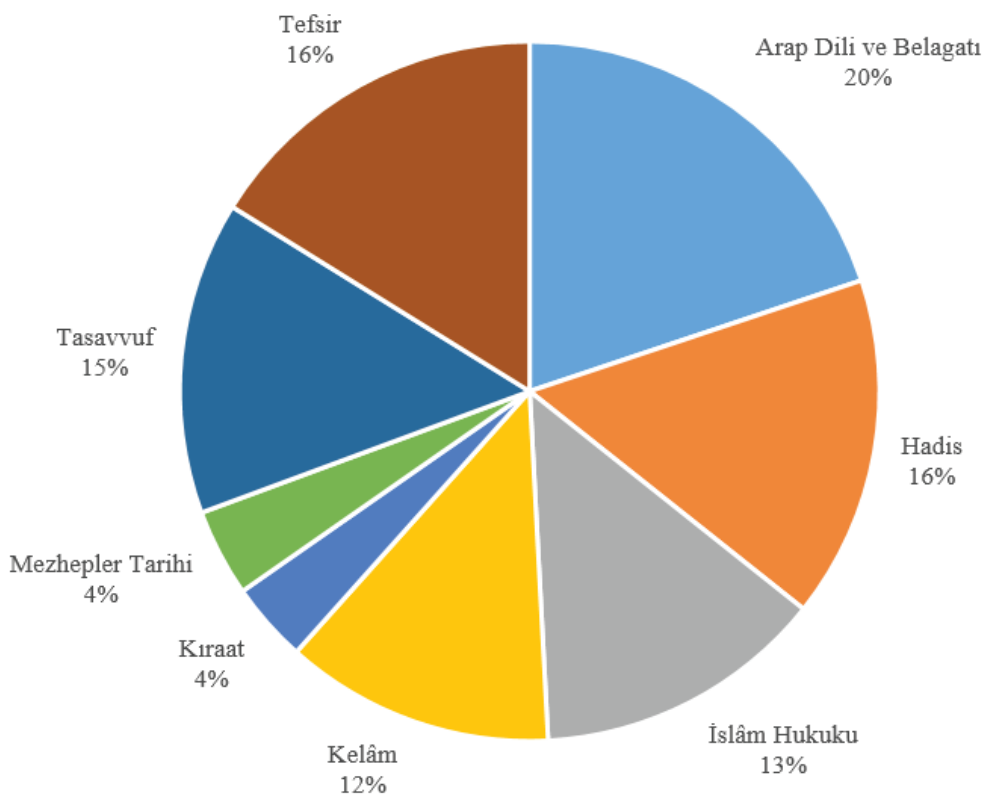


Tablo 5: Kadın Akademisyenlerin Temel İslâm Bilimlerindeki Unvan Açısından Dağılımları

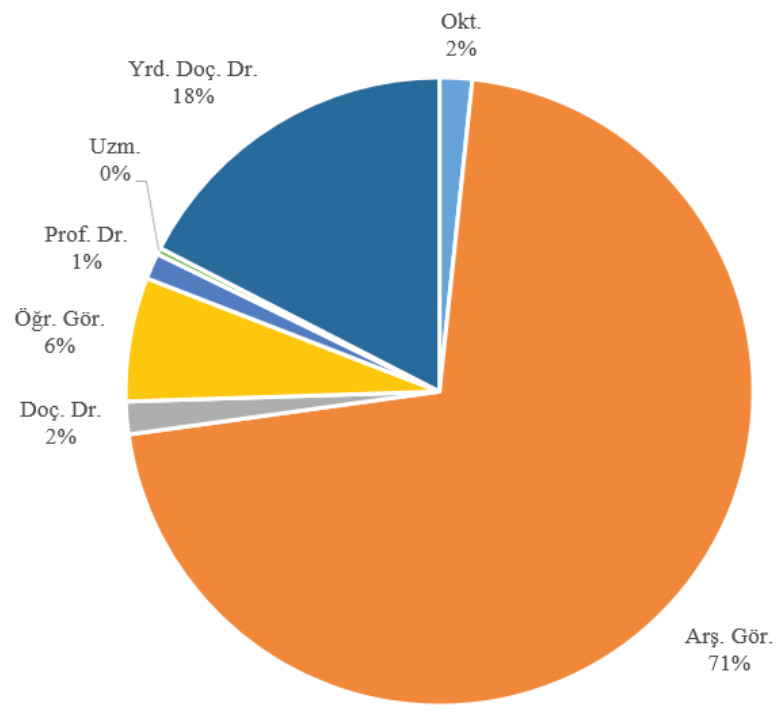

Tablo 6: Kadın Akademisyenlerin Felsefe ve Din Bilimleri ABD İçindeki Dağılımları

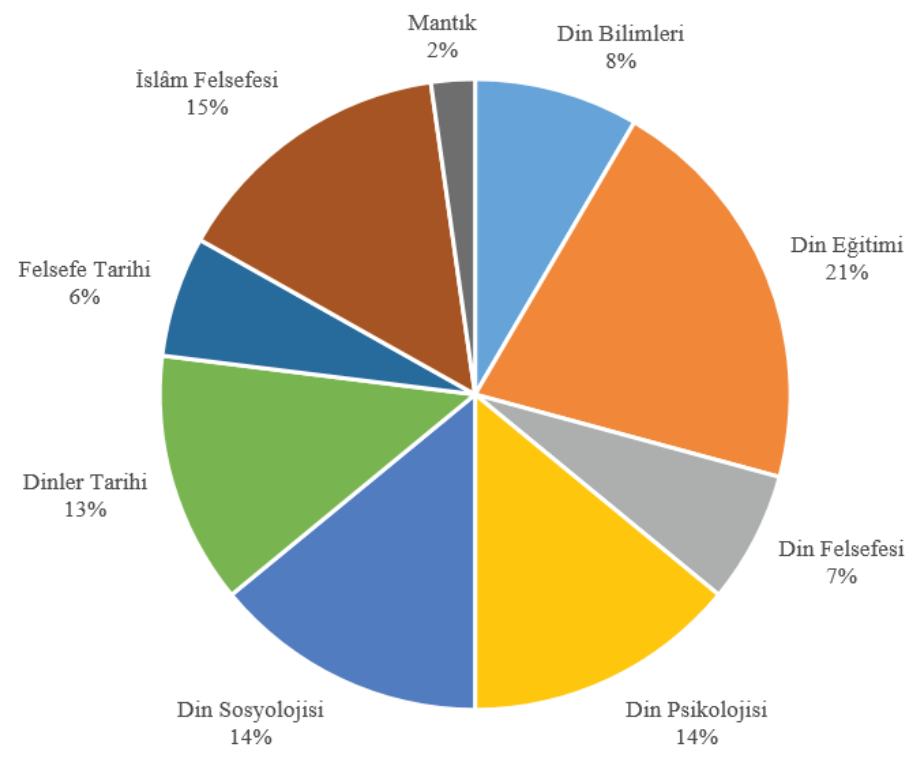


Tablo 7: Kadın Akademisyenlerin Felsefe ve Din Bilimleri İçindeki Unvan Dağılımı

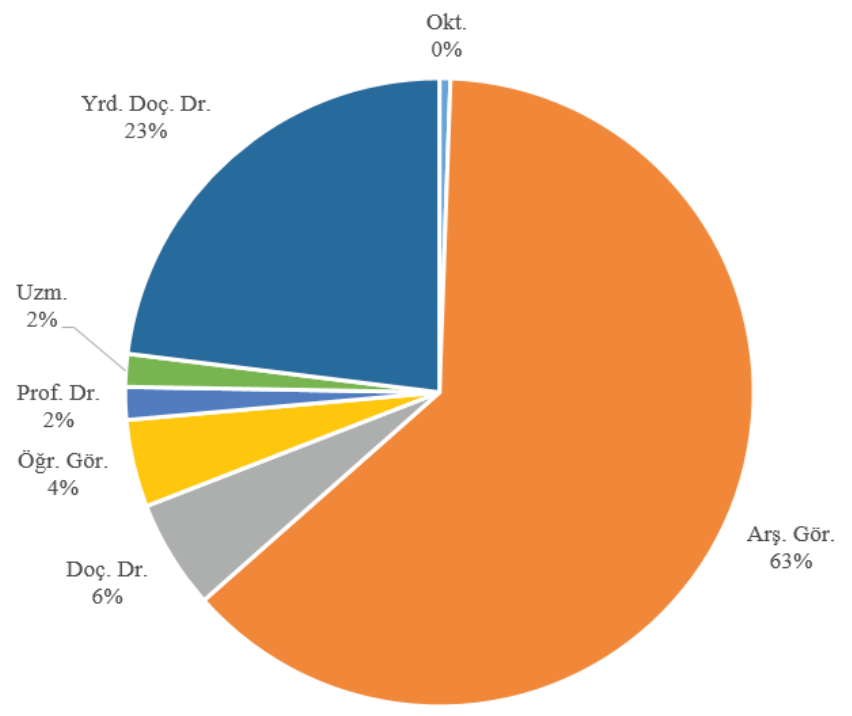

Tablo 8: Kadın Akademisyenlerin İslâm Tarihi ve Sanatları ABD İçindeki Dağılımı

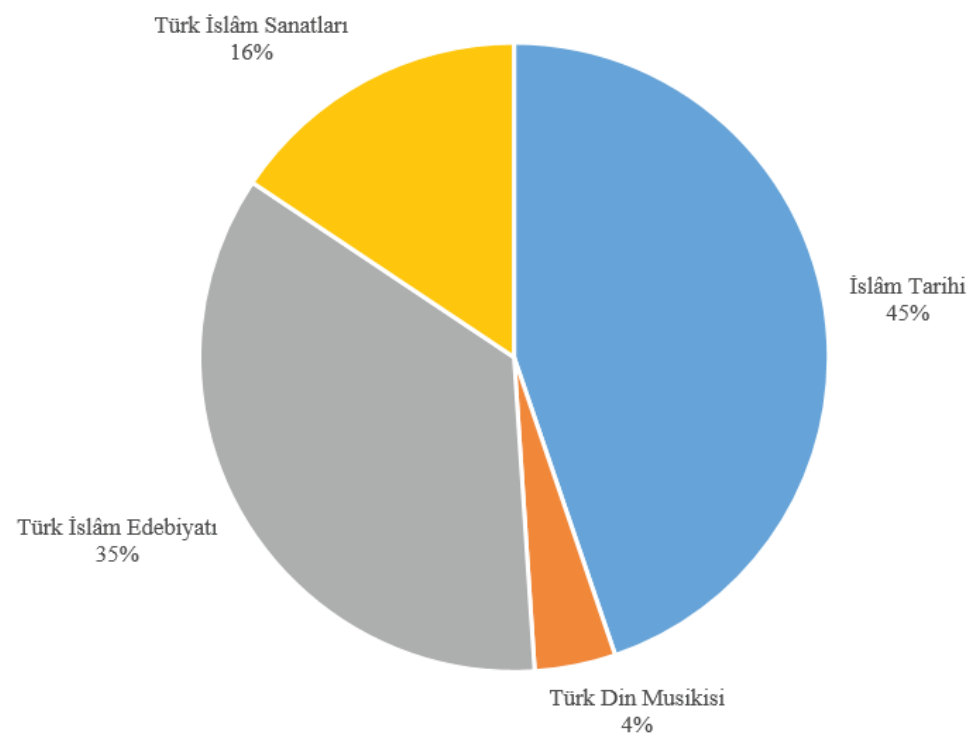


Tablo 9: Kadın Akademisyenlerin İslâm Tarihi ve Sanatları İçindeki Unvan Dağılımı

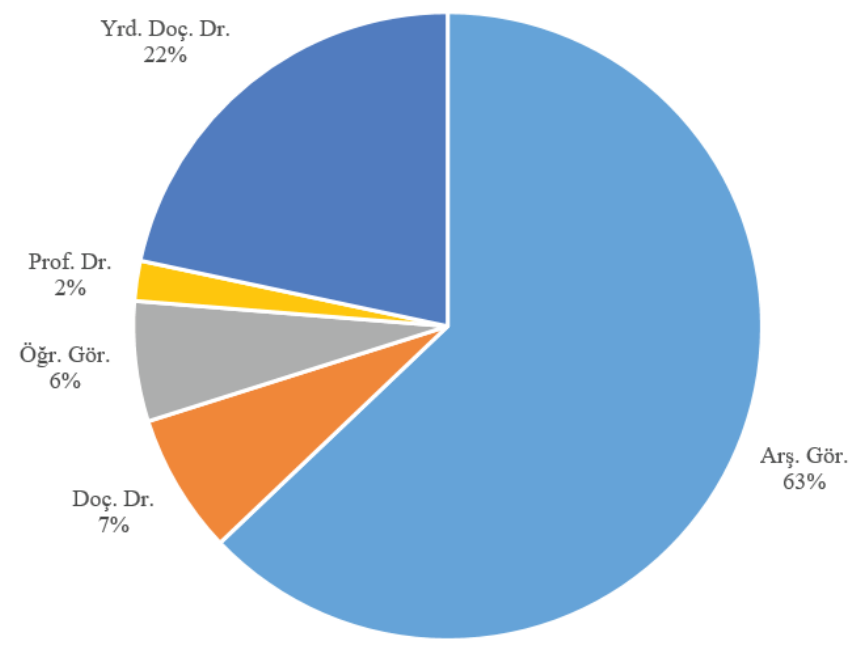

